

Digitized by the Internet Archive in 2008 with funding from Microsoft Corporation 
Sir William Henry Flower, K.C.B. 
s. 
4. 4

s

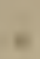

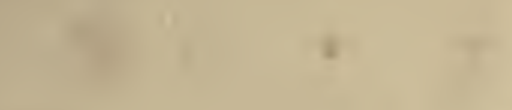

$=$ $\sqrt{2}+x^{2}$

$=$

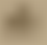

$x$

at

a

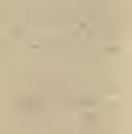




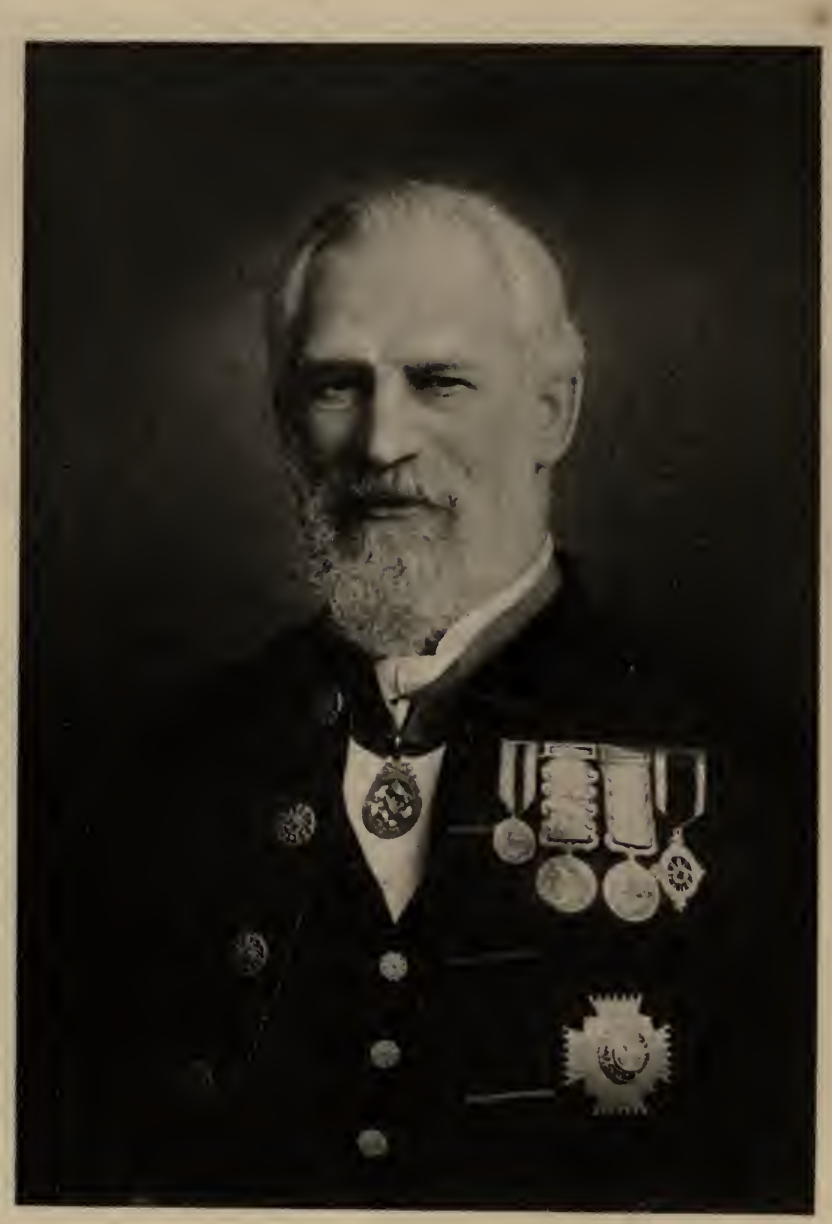

dir- Clilliam Flower. K.C.SB. 


\title{
Sir William Henry Flower
} K.C.B.

\author{
F.R.S., LL.D., D.C.L.
}

Late Director of the Natural History Museum, and

President of the Royal Zoological Society

\section{A Personal Memoir}

BY

CHARLES J. CORNISH, M.A., F.Z.S.

AUTHOR OF 'THE NATURALIST ON THE THAMEs,' 'WILD ENGLAND'

'ANIMALS AT WORK AND PLAY,' etc.

\section{ZLominan}

\section{MACMillan AND CO., Limited}

NEW YORK : THE MACMILLAN COMPANY

$$
\text { I } 904
$$




$$
\begin{aligned}
& \text { QL } \\
& 31 \\
& \text { F6C8 }
\end{aligned}
$$

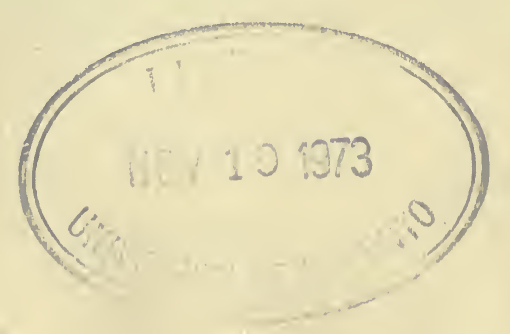




\section{PREFACE}

ThE death of Sir William Flower in 1899 was a personal sorrow to so many friends in all stations of life, and a cause of almost personal regret to so many of the public, that a memoir of his life might have been expected earlier. But to any one who reads the following pages it will not come as a surprise that the loss of so attached a husband and father made it a task of a trying kind to members of his family to arrange and recall the memorials of a life so deeply regretted.

His youngest son, Mr. Victor A. Flower, collected and classified most of the material available in the form of early letters and general memoranda during a visit to England, before returning to professional work at Singapore, and wrote the first two chapters as they stand here. But as Sir William's necessary correspondence increased, the recipients were naturally more diffused and the matter more condensed; consequently this source of information became less available as an aid to the setting out of his later and more important years. If in the chapters which ensue the personal 
element is accorded rather more space than might have been expected in a memoir of a distinguished man of science, and any critic cares to press this point, the writer is prepared to say mea culpa.

Much of Sir William's work in life is its own record, more especially the lasting monuments in the cases of the Natural History Museum and in the Museum of the Royal College of Surgeons. But his character and charm in social and family life were such that any memoir of him would be incomplete and one-sided were an account of him in these aspects entirely omitted.

To Mr. L. Fletcher, F.R.S.; Mr. G. A. Boulenger, F.R.S.; Mr. Charles Fagan, Secretary of the Natural History Museum; Mr. J. W. Clark, Registrary of Cambridge University; to the members of Sir William Flower's family, and especially to Lady Flower, the writer is more particularly indebted for assistance and information. But each and every one of the late Director's friends have most readily contributed their recollections when asked, with expressions of warm regard for his memory.

An estimate of Sir William's great and prompt service to the better understanding of the facts of evolution, at a time when the knowledge of these facts was confined almost entirely to specialists, will be found on page 57 , and in chapter v., pp. 64-65 and 66-68.

Those who have only seen his method in the 
lucid order of the Great Hall of the Natural History Museum, which has been copied in every leading zoological museum in Europe and in the United States, may not be aware that he originated this means of letting. nature tell its own story of the laws of evolution within little more than three years after the publication of the Origin of Species.

His early letters as a young army surgeon in the Crimea, for which service he volunteered, may probably have an added interest when compared with recent experiences in South Africa, and in view of the present invasion of Russian territory by Japan.

C. J. CORNISH.

ORFORD HOUSE,

ChISWICK MALL, February 1904. 



\section{CONTENTS}

CHAPTER I

Boyhood and Education, I831-I854.

PAGE

CHAPTER II

The Crimea, I 854 -1 855

I 2

CHAPTER III

Marriage and Early Professional Life

CHAPTER IV

Life in Lincoln's InN Fields - The Hunterian Museum . $\quad . \quad$. $\quad . \quad$. 52

CHAPTER V

The Hunterian Museum-continued . . . 64

CHAPTER VI

Family Life in Lincoln's Inn FieldS

CHAPTER VII

Character and Friendships . 


\section{CHAPTER VIII}

Later Work at Lincoln's InN Fields.

\section{CHAPTER IX}

Appointment to the Natural History Museum

\section{CHAPTER X}

The Natural History Museum

\section{CHAPTER XI}

The Natural History Museum-continued . $\quad{ }^{2}$

\section{CHAPTER XII}

Studies of Whales and Whale Fisheries . 166

\section{CHAPTER XIII}

Essays on Museums.

\section{CHAPTER XIV}

ANTHROPOLOGY

CHAPTER XV

A Visit to Tennyson

CHAPTER XVI

Later Days at the Natural History Museum 


\section{CONTENTS}

\section{CHAPTER XVII}

Last Years at the Museum.

\section{CHAPTER XVIII}

His Last Years

\section{APPENDIX I}

Notes on the Medical Arrangements of the British Army in the Crimea.

\section{APPENDIX II}

Hunterian Lectures Delivered at the Royal College of Surgeons . . . . 250

\section{APPENDIX III}

List of Published Writings .

$25^{\mathrm{I}}$

\section{APPENDIX IV}

Memorial Tablet

264

INDEX .

Frontispiece

\section{LIST OF PLATES}

I. Sir William Flower, K.C.B.

- $\quad 36$

3. Georgiana Rosetta Flower, i 859

44

4. Professor Flower, F.R.S., I 883 .

5. Sir William Henry Flower, K.C.B. 



\title{
CHAPTER I ${ }^{1}$
}

\author{
BOYHOOD AND EDUCATION
}

I $831-1854$

William Henry Flower, third son of Edward Fordham and Celina Flower, was born on the 3 oth November 1831 at his father's house in Old Town, Stratford-on-Avon.

$\mathrm{His}$ father, who was born at Hertford in 1805 , was the youngest son of Richard Flower of Marden Hill in Hertfordshire. Much of his early life was passed in America, where he took a keen interest in sport, and a still keener interest in the struggle for the suppression of the slave trade. After his marriage he settled at Stratford-on-Avon, where he founded the brewery which his sons afterwards extended into the most important industry in the place, and was well known for the active part he took in all local affairs, especially in organising the Shakespeare Tercentenary celebrations in 1864 . In I $87 \mathrm{I}$ he moved to London, where his strikingly-

1 Chapters I. and II. were compiled by Mr. Victor Augustine Flower, Sir William's youngest son. 
handsome figure was to be seen riding almost daily in Hyde Park up to the time of his death in 1883 . During the latter years of his life he laboured incessantly for the good of animals, especially horses, his main efforts being directed towards the abolition of bearing-reins and the better paving of the London streets.

His mother was born at St. Albans in 1804 , and died at her residence, I 6 Hyde Park Gardens, in I 884; she was the daughter of John Greaves of Radford Semele, Warwickshire, and sister of Edward Greaves, who represented Warwick in Parliament for many years. She, too, was tall, of strong character and pronounced literary tastes.

To Edward Fordham and Celina Flower were born four children, the eldest of whom, Richard, died in infancy; the second son was Charles Edward, the founder of the Shakespeare Memorial and the initiator of many beneficent works, who lived at Avonbank, Stratford-on-Avon, till his lamented death in 1892 ; the third is the subject of this Memoir; and the youngest, Edgar, born in 1833 , of Middle Hill, Broadway, Worcestershire, in which beautiful house he died in 1903 .

Flower's early life was passed very quietly at Stratford, then a small and remote country town. Much of his time was spent out of doors, but the foundations of his education were being carefully laid by his mother, who had a great belief in exercising mind and memory by reading and reciting poetry, 
and was herself well read in the best English literature, and delighted in reading aloud, which she did remarkably well.

From his earliest years Flower was devoted to natural history; his brother, Charles, writes in his diary :-

In June $184 \mathrm{I}$ we all went to Scarborough and spent the summer-till the 29 th Sept.; this was a delightful time. The museum at Scarborough was a great source of interest to us, and we used to go long walks "geologising," carrying our dinners with us. In one of these walks we met with Dr. Amory, who took an interest and helped us in our scientific pursuits. William learnt to stuff birds, and acquired a taste for studies which afterwards led to his becoming a surgeon.

Of his first "museum" and collections he has written in Essays on Museums, a few paragraphs of which may well be introduced here.

My first "museum" was contained in a large, flat, shallow box with a lid, and I made cardboard trays which filled and fitted the bottom of the box, and kept the various specimens separate. Everything was carefully labelled, and there was also a manuscript catalogue in a copy-book. When the box was outgrown it was superseded by a small cabinet with drawers, then by a cupboard; but before I had left the parental home for college, an entire small room was dignified by the name of my "Museum." It was the love of curatorship which thus grew up within me, without the remotest external influence or inherited predisposition towards it, that determined my after career, and led to such success as I have met with in it. My boyish fondness for dissecting animals and preparing their skeletons at that time could find no nearer outlet in any academic career than in the pursuits of a medical student, and the anatomical museum of my college was at first to me a subject of much greater interest than the wards of the hospital-so much so, in fact, that while still 
in my second year of studentship the curatorship falling vacant, I was asked to undertake the office. Here I was in my glory, and although later on the more practical work of the surgical profession had its attractions also, - attractions which at one time nearly carried me off into the stream of London hospital practice,-I finally returned to the old love, and, through a succession of fortunate incidents, the museum under my care, instead of the one little box with which I began, is now the largest, most complete and magnificently housed in the world.

One of the first specimens I possessed was a little stuffed bird with a brown back and white underneath and a very short tail. I saw it in the window of a pawnbroker's shop in my native town, Stratford-on-Avon. I often passed the shop and looked at it with wonder and admiration. At last I summoned up courage to ask the price. "Threepence," was the answer. This was a serious consideration; but the financial difficulty being overcome, I carried the bird home in triumph. Having access to a copy of Bewick's British Birds, I identified it as the dipper or water-ousel, and even learnt its scientific name, Cinclus aquaticus. It was wretchedly stuffed. Though more than fifty years have passed since I saw it last, for during an absence at school it, with many other treasures, fell into places where "moth and rust do corrupt," its appearance is still fixed in my mind's eye, with its hollow back and crooked legs sticking out of impossible parts of its body. That bird became part of my permanent stock of ornithological knowledge, and ever since, whether by a mountain stream in the Highlands of Scotland, or a rocky river in the Harz or Thuringian Forests in Germany, when I see a dipper flitting over the rushing water or diving beneath the surface, it seems an old familiar friend of my childhood.

We get an interesting glimpse of him as a boy in an undated letter from his aunt, Amelia Greaves, to her sister, Mrs. E. F. Flower:-

My dear Celina-I only write to tell you of the admiration which William gained yesterday. I assure you I felt very proud of 
my nephew in "The Museun," 1 and it was very pleasant to see how Mr. and Mrs. Taggart appreciated him. I wish you had been there to see the boy; to see the perfect simplicity with which he knew and explained everything. Mrs. Taggart said she never had seen such a remarkable boy, and wanted to know "where and how he had been educated," and then she predicted all sorts of grand things to come. I thought the Taggarts delightful people; it was amusing to see the offhand way in which William took Mr. Taggart's card and invitation and then strapped on his knapsack and walked off.

In January 1842 Flower was sent to a small boarding school at Edgbaston, near Birmingham, but he only stayed there one quarter, owing to his health, which was then, and for some years after, very delicate; this occasioned his living a great deal at home with his mother.

His health being somewhat restored, in January I 844 he was sent to a rather remarkable school at Worksop, of which the Headmaster was a German, Dr. Heldenmaier. In this school not only were the more ordinary subjects taught, but also astronomy, anatomy, elocution, logic, botany, mineralogy, and surveying. The life must have been hard for a delicate boy of twelve, as they had ten hours of lessons daily, and their "leisure" was taken up with gardening, gymnastics, and making collections for the school museum. This latter was a great joy to him, and he writes in triumph to his mother in September 1844 that he has been made "Curator

1 The Museum was a room in his father's house at Stratford-on-Avon devoted to his collections. 
of the Museum." The hard work and long hours seem to have told on him considerably, but yet he wrote cheerfully every week to his mother describing fully everything he was doing. The following extracts will show how, even at school, he was still following up his favourite subjects :-

Worksop, Feb. 25 (1844).-As well as the book I have already mentioned $I$ have one on chemistry. One very nice thing here is that on Sunday evenings the large boys sing in the dining-room, and the little ones (those of the second singing class), me among them, have to come into the room and read or draw, whichever we please, and Mr. Richmond, who keeps Dr. Heldenmaier's collection of stuffed birds, always lends me one to copy. I have done a skeleton of a starling, a knot, which is a kind of sandpiper, and a water-rail.

Worksop, August 25, 1844.-Webster and I are very busy about natural history, always poking about for insects and reading Jessie's Gleanings in Natural History and Mudie's Feathered Tribes of the British Islands.

Worksop (March 1845).-Dr. Heldenmaier has given us a room in the other house for dissecting. I wish you could see us there with knives and scissors, cutting and injecting away. . . Since I have been here I have dissected, or helped in dissecting, two good-sized dogs, one puppy, one cat, five rats, two rooks, one jackdaw, etc. ...

Worksop, Feb. $4(\mathrm{I} 845)$.-Oh! the chemistry here is beautiful.

Owing to his delicate health he had to leave Worksop in the spring of 1845 , and for more than two years he lived at home, with the exception of a short time at a school at Eastbourne, till in the autumn of 1847 , on entering University College, London, he went to live at Cloudesley Terrace, Islington. At this time, among the teachers at 
University College were men of exceptionable ability, such as Professor George Busk and the cultured surgeon Campbell de Morgan, while among those of the students who became his lifelong friends were the Judge, Sir Edward Fry, and Lord Lister, President of the Royal Society. At first he only took up the ordinary Arts course, in which he matriculated in July 1849 , believing that "the study of medicine is, after all, the essential thing by which I must stand or fall in the world," but, wishing "to turn his love of natural history to advantage," he afterwards entered on courses in Zoology, Comparative Anatomy, and Anatomy and Physiology, for which courses he obtained a gold and a silver medal. Writing to his mother in explanation, he said :-

A knowledge of birds alone is of very little use; I want a general and scientific knowledge of the whole animal kingdom, particularly of the lower classes, mollusca and radiata, of which I know next to nothing, and without which I could never turn my love of natural history to any advantage.

Further on in the same letter he describes a knowledge of the above subjects as "indispensable," and laments not having time to take up "chemistry and geology, which are all so useful."

To the boy of sixteen, born and brought up in the country, and who had lived so much of his life at home, London seemed at first very hard and unsympathetic. One letter (of many) will be sufficient to show him as he was during his first months in London :- 
36 Cloudesley Terrace, Jamuary $30,1848$.

My DEAR MAMMA-Imagine to yourself me, standing in ecstasies of delight over the just-arrived box, with hands trembling with impatience, undoing the cord and snatching off the lid, then pausing a moment where to commence the attack among the tempting-looking packages of paper. Presently four pieces of wood tied together and stuck in a corner are spied, and a brown bird is brought to light; then the stockings, least interesting but not least useful, are thrown out; then two mince pies, which did not live many seconds to enjoy the smoky atmosphere of London, for the hands, or rather mouth, of the destroyer was soon at work on them; then cake, jam, nuts, pies, books, etc., etc., follow in quick succession: such a scene was enacted in this room about three o'clock this day;-but after pleasure a reaction often follows; it grew dark, and I sat down by the fire, and I thought of Home and you all and bygone days and-cried. I am not generally melancholy now, because I have plenty to do, but if ever I sit still for a few minutes doing nothing, and almost every night when I go to bed, it comes on. What a singular thing it is that the farther you look back on what has happened, and the farther off it you are, it seems so much the happier; time and distance throw such a charm over everything. I think sometimes that I was happy once but am not now, but really it is not so; now, for instance, I think, oh, how happy I was at such and such a place, but when I really and earnestly think of the circumstances of it, I find that there were just as many troubles and cares and disappointments then as there are now, but these are forgotten and only the good impressions retained; that is why people say childhood is the happiest time of life; it seems so at first thoughts, but I think that happiness does not depend on age but on a good conscience.

This last reflection, together with the following undated extract-" The Bible came home to-day; I hope it will be a constant companion and friend as 
long as I live" - show characteristic lines of thought which he adhered to all through life.

However, he soon settled down to regular London life, broken only by a run down to his home at Stratford for a few days' hunting with his father, or by a day on the Essex marshes with his long singlebarrel gun shooting wild duck and getting an occasional goose. From these latter expeditions the bag was usually brought back for purposes of dissection and stuffing. Another means of acquiring specimens was by going down to Leadenhall Market in the early morning and looking through the birds as they came in. In one letter he records having got specimens of pintail, curlew, tufted duck, and brent goose. The longer holidays were nearly all devoted to walking tours, usually with his brother Edgar, or with his life-long friend Septimus Sibley, or with Harry Greenhow, who afterwards went through the siege of Lucknow.

"The most substantial parts of a journey are the letters written; talking vanishes, impressions fade, but writing endures, so write, write and sketch." So wrote Mrs. Flower to her son; and accordingly from every stopping-place he sent her long descriptive letters, and a sketch-book always accompanied him, in which he recorded everything that struck him as being of interest, whether it was a building, a strange animal, or a fine piece of natural scenery ; the humours or discomforts of their travels, too, are frequently vividly portrayed. Among other 
places visited in this way were Wales, the Lakes, the Wye district, the Rhine, Holland and Belgium, the Black Forest, the lower Rhone, the Pyrenees and Switzerland. Even in those days the Museums and Zoological Gardens they came to in their walks were always the first objects of interest.

In March I852 Flower read his first paper before the Zoological Society of London (of which he had been elected a Fellow the year before), "Notes on the Dissection of a New Species of Galago." $\mathrm{He}$ was also now contributing many papers to the University College and Middlesex Hospital Medical Societies. In March 1853 he was appointed Junior House Surgeon to Middlesex Hospital, and six months later Senior House Surgeon. In March I854 he passed the examination for Membership of the Royal College of Surgeons. In spite of all his other duties he undertook the work of Curator of the Middlesex Hospital Museum, to which he added many new preparations, and the general condition of which he much improved, as the Committee emphasised in their report every year. In January I 854 they wrote: "The Committee have great satisfaction in recording their sense of the excellent order in which the Museum has been kept, and the admirable manner in which the preparations have been put up. This reflects the greatest credit on Mr. W. H. Flower, inasmuch as he has been engaged during the greater part of the year in performing in a very 


\section{JOINS THE ARMY MEDICAL STAFF II}

efficient manner the duties of House Surgeon to the Hospital."

These two appointments he held till April 1854, when, owing to the rumours of approaching war, he threw them up in order to join the medical staff of the Army. 


\title{
CHAPTER II
}

\author{
THE CRIMEA
}

$$
\text { I } 854-1855
$$

DURING the opening months of 1854 rumours of the coming war with Russia were exciting every young Englishman. It had been Flower's intention to go abroad for a couple of years to study surgery at the French and German universities, but when he learnt that Dr. Sharpey of University College, who had been asked to send in the names of some "really good men" to the Director-General of the Medical Department of the Army, had included his among them, he gave up his original plans, and in the expectation of being soon employed on active service, decided to enter the Medical Department of the Army. His family received the news with some dismay, their letters calling forth this characteristically philosophical summing up of the question :-

\section{March 31, 1854.}

MY DEAR MOTHER - "Too anxious" I think you rightly call yourself; but do not let imaginary fears and dread of almost impossible dangers interfere with so brilliant an opportunity of 
acquiring experience and knowledge such as now presents itself, as every one whose opinion is worth having about here says without doubt it is. I should be very sorry indeed to do anything that would give you pain and trouble; but then, if the occupation of a medical officer in the Army does so on account of the danger, what is there that I can do that is not attended with danger? ' Every time I make a post-mortem, or go into the wards among the patients with fevers, I encounter a certain amount of danger. How can I venture to trust myself in a railway carriage or a steam-boat? What situation is there in which there is not more or less danger? And one who is always dreading it must be miserable indeed! I might get shot by a Russian cannon-ball, and I might get knocked down and run over by an omnibus in Oxford Street; the chances of the latter are almost as great as the former, but they do not deter me from walking in the street in question. Edgar might break his neck or his leg out hunting, but I hope that fear of such an accident will never prevent him from enjoying that sport, or make you miserable when he does so, though to pursue it constantly is attended with risks quite as great as mine. The risks that are really tangible are from the climate and disease of the countries, but the greater these are the more advantageous must be the position from a medical point of view.

The decision once made, very little time was lost. On the 8th April Flower passed the medical examination. Two days later he reported himself to the Principal Medical Officer at Fort Pitt, Chatham :-

Chatham, April ro, 1854.-To-day I have commenced my "Military" life. What a strange thing it seems! I am beginning to get an insight into what appears quite another branch of human nature; this place certainly abounds with the "quality, pomp, pride, and circumstance of glorious war," and so far is pleasant enough. We live at our own expense, receive no pay, and wear plain clothes, ... and are carefully supervised by the 
P.M.O., whose duty, amongst other things, seems to consist in reprimanding men who wear loud pattern shirts or broad-gauge trousers.

However, he was not long at Chatham, receiving orders to report himself as Assistant Surgeon to the Depôt Battalion at Templemore, where he arrived on the 28th April. Here he found plenty to do, as there was a large number of cases in the hospital, and for a time he was the only surgeon; and even when, a little later, a senior surgeon was appointed, the work was not much decreased, for the newcomer was "a very jolly old file, whose greatest sphere of action seems to be at the mess tablea regular old army bird, always impressing on me his maxim 'Never do more work than you can possibly help,' but very knowing with the men, down to all their tricks to get off duty, etc." Flower soon saw that the uniform as then worn in our army was most unsuitable for active service or for getting the best work out of men at peace manœuvres, and began to advocate the abolition of the stock, and other changes. "The Colonel is very old-fashioned in his notions; we have great arguments with him at mess about the dress and accoutrements of the British soldier, which he considers the most perfect thing in the world; nothing can annoy him more than saying anything against that remnant of barbarism, the leather stock; but he is a goodtempered and gentlemanly man, so we get on very well." While these discussions were going on 
"one of the sentries was found dead at his post. I was called up to him, but life was quite gone. Dr. Breslin is a great enemy of soldiers' stocks ; the Colonel, on the other hand, an immense advocate for anything that is old-fashioned; here was a grand chance for him to annoy the Colonel and cry down the stock; so though the real cause of death was rupture of the heart, Dr. Breslin persuaded the jury that it was the stock, showed them an illustration, the picture in last week's Punch, which they firmly believed was an actual portrait of one of the soldiers in the Eastern Expedition; they accordingly returned a verdict to the effect that the deceased died from strangulation by the stock!"

At Templemore he remained for nearly three months, till on July 15 he wrote to his father :-

The happy moment has at length arrived; to-morrow I bid adieu to Templemore; the order came this morning for me to join the 63 rd Regiment, now at Cork, waiting for embarkation to Turkey.

However, there were further delays, and it was not till Sunday, July 23, that the Avon, Captain Ellison, a paddle-wheel steamer of 1800 tons, with on board the headquarters and eight service companies of Her Majesty's 63rd Regiment of Foot and two companies of the 46th Regiment, in all about 1220 men, sailed from Queenstown for the East.

The voyage was slow and uneventful; at Malta they took in tow a brig containing stores and 
CHAP.

provisions and a barge containing a pontoon bridge.

There were a good many vessels in sight all day, several of them being French transports, schooners, and brigs of one to three hundred tons, bound in the same direction as ourselves, and having on board cavalry and stores; what a miserable and uncertain mode of conveyance these seemed, compared with our mighty steamer! Early this morning we fell in with the Medora, transport ship, having Artillery on board, and as she was becalmed we took her in tow, as well as the other two, so our procession now was very imposing. ${ }^{1}$

On the 7 th of August they arrived off Constantinople. In this neighbourhood they remained till the end of the month, sometimes on board ship, sometimes in camp in Sultan's Valley near Beicos, when they sailed on, first to Varna, and afterwards to Baltchik. Sickness had already set in ; before they left the Bosphorus there had been nine deaths from cholera in the $6_{3}$ rd Regiment alone, and in some other regiments many more.

Ships and men were now being hurriedly assembled in Varna Bay; great was the excitement on board the Avon, something was really to be done now, but nobody knew what, till on the 6th September they received orders announcing that the invasion of the Crimea had been determined on.

On the following day the combined fleets of England, France, and Turkey, together with the transports carrying troops and stores, nearly 700

1 From Diary of the 5th and 6th August 1854. 
vessels in all, sailed out from Varna, making a spectacle the like of which will never again be seen in the history of the world. Men-of-war had now attained to about the height of their magnificent appearance; steam was coming in, but it was not yet of sufficient importance to modify the shape of hulls, or to diminish the height of masts or the spread of canvas.

A more magnificent, spirit-stirring sight can scarcely be imagined than this, perhaps the most powerful Armada that ever was collected together, putting out to sea. The beautiful order in which the mighty steamers, each followed by two large ships in tow, wheeled round out of the bay and fell into their respective positions, while the line-of-battle ships hovered round, whipping up the slow ones into their places and constantly firing guns as signals; the fineness of the day, the freshness of the breeze, the good spirits every one seemed in, all contributed to make it an event never to be forgotten by those who had the privilege of witnessing or sharing in it. ${ }^{1}$

Then followed a week at sea, sometimes moving ahead, sometimes at anchor, every fresh move giving rise to much discussion and speculation, till on the I 2 th land was sighted, and two days later, on Thursday, September I4, the whole army landed, quite unopposed, about 28 miles north of Sebastopol.

Thursday, September 14.-Disembarkation of the allied armies on the coast of the Crimea commenced this morning. The place appeared to have been made by nature for such a purpose. The two places where the French and English disembarked were exactly similar, consisting of a low sandy beach about a mile long, and perhaps a quarter of a mile broad, each protected behind by a

1 From Diary of Thursday, September 7,1854 . 
shallow, square-shaped salt lake. Between the two lakes was a level plain or table-land, partly covered by corn, which had just been cut but not carried. The greater part, however, was uncultivated and covered with coarse grass and immense quantities of wormwood, which gave a most fragrant odour as you walked over it. Looking northward nothing but level plains are to be seen; the southern horizon is bounded by the outline of a chain of fine-looking mountains. Being in the last division of infantry, the Avon lay one of the farthest out to sea, and our turn for landing came last, so we spent the greater part of the day in watching the boats coming to the side of the other ships, being filled with red-coated men, and then towed off to shore by little steam-tugs. Our turn at length came about 4 o'clock; a troop of boats came alongside, and in about an hour the whole regiment was safely landed on the Emperor of Russia's territories, without passport or permission.

We were ordered to land in full dress, ${ }^{1}$ with no baggage but what each officer could carry himself, including rations of salt pork and biscuits and a keg full of water to last three days. The night soon coming on after we had taken up the position assigned to us on the beach, we began in earnest to experience the hardships of war. We laid ourselves down in the sand with our great-coats around us, and began to sleep comfortably enough; but before long I awoke with a most uncomfortable sensation of dampness, and found it was pouring with rain. It had been threatening, and indeed raining, a little all day long, but now it came down vigorously; however, there was nothing to be done, so I pulled my coat closer round me and tried to sleep again. This, however, was impossible, and the cold and damp increased so that there was nothing for it but to get up and walk about. It was. now about one o'clock, but I found every one on the move from the same cause ; a heavy surf had also risen on the sea, by which many of the boats engaged in landing horses and artillery late in the afternoon were wrecked and cast on shore, and tales were circulated of men being drowned and others having narrowly

1 Full dress : cocked hat, scarlet coatee, gold epaulettes, sword, pistol, flask, and great-coat. 
escaped. This circumstance, however, proved a blessing to us in one respect; the stranded boats were soon seized upon by our men, broken into pieces, and their remains converted into a number of blazing fires, round which we collected in groups and spent the remainder of the night; the light of the fire revealed a set of as unhappy-looking countenances as any one might wish to see. At length, however, it ceased raining, and the light of morning began to appear, to our infinite satisfaction.

Friday, September I 5. - The sun rose over the lake, and the brilliancy and freshness of the morning almost made us forget the misery of the night. The surf was still so high that disembarkation was stopped until the afternoon, and we found that it was true that a man and several horses had been lost during the night. I could not help feeling that if the storm were to continue, our position would be somewhat critical, in an enemy's country, without artillery, cavalry, provisions for more than three days, or means of retreat. In the afternoon the ships were at work again, but the only way in which the horses could be landed was by throwing them out of the boats and letting them find their way as they could to the shore. In the morning I took a walk along the coast to the French landing-place and encampment. In one respect they were much more comfortable than we were, in that they had tents to sleep in-little low ones into which four men could just creep, and which are carried on the march a quarter by each man. In the evening we made our beds on the sand as before; fortunately it was fine though very cold.

Saturday, September 16.-Went back to the ship to superintend the removal of about forty invalid soldiers to the Kangaroo, which ship is going to take them to the hospital at Scutari. On my return I was delighted to find our tents had arrived and were put up, the luxury of which no one can appreciate who has not been sleeping in the open air in cold weather.

Sunday, September 17 . - The process of disembarkation is going on briskly, the beach presenting a scene of the most animated and lively description. Foraging parties that we have sent out to the neighbouring villages have been generally very successful, and have brought in an immense number of araba waggons, oxen, camels, horses, sheep, goats, etc. The inhabitants mostly came 
with them, and are taken into our service, paid and rationed for looking after the oxen and driving the waggons; they are all Tartars and Mohamedans, and profess to entertain more sympathy for the Turks than for the Russians. The camels are of the sort with two humps. Very little use seems to be made of them, two of these huge beasts being always yoked in a small araba waggon, and they seem never to be used as beasts of burden.

Monday, September 18. - The disembarkation of horses still continues. I went for a long walk with another officer, first to the French camp, where we saw eighteen Russian soldiers who had been taken prisoner; then we visited the Turkish camp and each of our divisions and the rifle camp in the village; this was situated in a hollow with a good many trees round it. The houses, now nearly all deserted, were very comfortable and wellbuilt, and the whole showed signs of civilisation, comfort, and cleanliness far superior to what I had expected. The great house of the village was an exceedingly pleasant country residence belonging to a Russian general. We went over it, and found it furnished exceedingly well; the inhabitants had evidently left it in a great hurry on the appearance of our troops, but the servants all remained, and were very civil in showing us over the rooms, which we left in exactly the same state as we found them, with the exception of a slight diminution in the stock of wine. There was an excellent library, almost entirely of French books; among others I saw Shakespeare's works, Marryat's, and other English authors translated into French. A very handsome illustrated Life of Napoleon was lying on the drawing-table, also a cardbasket, drawing material, letters, music, etc. There was a piano too, and round the house a goodly-sized garden, though badly kept up. On returning in the evening we found to our great grief that the tents were all to go back to the ships, and that we should have no chance of seeing our baggage for some time to come. ${ }^{1}$ So we had another night in the open air, the last in our present situation, to-morrow being appointed for commencing the march.

1 It was a month before Flower got his tent again, and more than nine weeks before the baggage was landed from the Avon. 
Tuesday, September 19.-Early this morning a general move took place, the whole army marching off towards Sebastopol ; the 63rd Regiment alone was an exception, being left on the beach to assist the ships in clearing away some stores which had been landed and were not now wanted, and a number of sick and weakly men who had been left behind from different regiments. This occupied nearly the whole of a very hot day, but about half-past five in the afternoon we set off in the direction the rest of the army had taken; but it appears we did not know exactly which this was, for about an hour after dark we found ourselves in the village which I visited yesterday, with no trace whatever of the rest of the division. Even on this short march we found out one of the troubles of medical officers in war time; no provision whatever had been made for the conveyance of men who fell sick on the way; in vain had we represented that such was the case to various authorities; the only reply was that all the waggons were wanted for the commissariat. We certainly started off without a sick man, but owing to the heat of the day, the hard work the men had had, and the prevalence of diarrhœa and cholera as an epidemic in the regiment, men were constantly falling out of the ranks, unable to march a step farther; these we must have left to the mercies of the Cossacks if we had not fortunately found two arabas on our way, in which we managed to bring them all on to our destination for the night. The above-mentioned Cossacks are terrible bugbears to our army, but they appear to do very little or no damage beyond alarming timid sentries and causing whole regiments to turn out under arms at unpleasant hours during the night; they sometimes appear in the daytime, but always vanish on the least indication of our assuming a hostile attitude. Night alarms are often caused by a stray pony or bullock wandering too near the outposts; one of the latter was shot a few nights ago by a valiant sentry, and there is a story (I believe true) of a bold Highlander firing twice at a bush and then charging it with his bayonet before he discovered his mistake.

Wednesday, September 20.-All up and under arms before daybreak, but from some cause or other we did not move off our ground till ten o'clock. It was a beautiful morning; our route 
was across a fine open undulating country, following the line of the coast, from which we were about three or four miles distant. Our little army presented a very pretty sight as it slowly moved along, the rear and flanks protected by some squadrons of the 4th Light Dragoons, which had been left behind for that purpose. About the middle of the day we halted, and our commander, Brigadier-General Torrens, made a speech to the men, informing them that he had just received intelligence that a battle was about to be fought by the army in advance of us, and that if we marched well we should be up in time for it, etc. ; so on we went again, but the heat of the day and the weight of the packs soon began to tell on our men, many of whom were mere recruits who had never marched before in their lives. Our waggons soon filled with sick men, and others kept dropping out every minute ; however, by using threats and persuasion alternately, getting the worst ones on to the waggons, carrying packs and firelocks for others, we managed to get them all along to a village near the sea, where we left the waggons and sick and weakly men under the charge of an officer and assistant-surgeon. This was about five or six o'clock, and we must have marched fifteen or sixteen miles; but the General wishing to share in the glories of the battle, ${ }^{1}$ of which we now heard the firing and saw the smoke in the distance, on we went again, at first pretty bravely, but the exhausted men began to fall out again; but as it was getting dark, and we saw from the lights ahead that we were near our destination, we left them in dozens on the ground, and as many of them were only exhausted, they came on again and joined us during the night or next morning. The lights we had first seen turned out to be, on our approaching them, a village on fire; a melancholy sight it was, too, as we passed between the smouldering walls and blackened and demolished ruins. Here we met stragglers from the main army searching for lost comrades; they told us of the dreadful battle that had been fought, and how their regiments had been cut to pieces; they spoke little of having gained a great victory - that was a matter of course. Then a dead body of an Englishman lay across our path, cold, stiff, and bloody.

1 The battle of the Alma. 
With what curiosity our men looked at it, and what a shudder seemed to run through them at the sight; but then came another, and another, and others with horrid wounds, groaning and crying for help, help which no one could give them. At length we came to the river; we were half-dying with thirst, but for a long time no one ventured to taste the water which flowed through this scene of death; but this feeling once overcome, they rushed eagerly to the stream, and very refreshing it was. We passed over a bridge the Russians had partly destroyed, but by this time repaired by our engineers, and reached our destined resting-place on the field where the battle had been raging during the day. Here we soon dropped down to sleep, not, however, before those lines of Campbell's came most forcibly to my mind-

When thousands had sunk on the ground overpowered, The weary to sleep and the wounded to die-

though we had not even the comfort of a pallet of straw.

"Moved our camp from the battle-field to join the 4th Division." "Marched to the Kutchka." "Marched to the Balbec." "Travelling slowly all night through the wood." And so on till the 3oth September, when, owing to inflammation of the eyes, brought on by exposure to the cold by night and to the sun by day, ${ }^{1}$ Flower was ordered to the hospital ships Hydaspes and Gertrude, where he remained till the $\mathrm{r}^{\text {th }}$ October, when he returned for duty to his regiment, which was now engaged in the siege of Sebastopol, the bombardment of which commenced four days later.

Balaclava, October II, I854.- . . Things are going on very quietly. We have not yet fired a shot, but are silently and (apparently) slowly making our preparations for opening a tremendous and simultaneous fire on the devoted city; they

1 Flower never fully recovered the sight of his right eye. 
keep up a constant cannonading at us, doing very little damage, however. I am very glad to hear that all the inhabitants appear to have left the town, and as we are going to attack them only on one side (the south), the Russian soldiers will have a back door to escape at ; and if they do it early they will save a good deal of trouble both to themselves and to us. . . .

\section{Camp, Heights above Sebastopol,} Sunday, October 22, 1854 .

DEAREST Mother-I have just received your letter of the 2 nd ult. You describe the home with the kettle on the hearth and you wonder what are my surroundings. They are different indeed. I am writing lying on the ground in a tent, also occupied by Drs. Lewins, Mills, and O'Dell, our only furniture being a railway rug, a blanket, and a great-coat apiece. The sun shining brightly outside, but instead of sounds of peace and comfort there is "the cannon's deafening roar"; such an eternal booming and banging, whirring of rockets and whistling of balls through the air you can scarcely imagine. This is the sixth day this has been going on without interruption, except a partial lull at night. Our camp is beautifully situated on a hill commanding a view of the whole town, and of our works too, just out of range of the balls, so we see everything that goes on; and an extraordinary sight it is, one set of men behind a wall of earth pounding away for a week at another set of men behind another wall, who return the compliment vigorously, but apparently with very little effect on either side-a curious way of settling the affairs of the world and restoring peace to the nations of Europe. . . . As the Avon has not yet come up, we are still totally destitute of baggage, even of a change of clothes, so that we are about as comfortless as may well be imagined, and heartily pray for the end of the campaign. It was very annoying to see "The Fall of Sebastopol" announced in large letters in the Times, when here we are and Sebastopol looking as lively as ever notwithstanding our six days' bombardment.

I do not know what the result of the siege will be, but there seems to be a great mistake somewhere, as every one believed that it was to be the work of a few days, or even hours, that 
when our batteries began to play on the town they must surrender at once; but instead of that, the more we fire at it the less likely we seem to make any impression on what must certainly be one of the most formidable places in the world. If this expedition should prove a failure, it would be a great blow to the English and French alliance, as they are sure mutually to throw the blame on each other.

The weather continues summerlike, though cold at night. Since the first night of our landing we have scarcely had a drop of rain. I do not know what would have become of us if it had been otherwise. I think this hard mode of life will do many of us a great deal of good. It is curious to see noblemen, officers of the Guards, etc., men brought up in every luxury, leading precisely the same life and feeding on the same rations as the common soldiers, but, of course, exercising the Englishman's privilege of grumbling and growling at everybody and everything, more especially at the Czar Nicholas, the author of all our troubles, who, of course, is duly anathematised by every officer and soldier in the army at every convenient time and opportunity. ...

Camp on Heights above Sebastopol, October 27, I854.

DEAR EDGAR-I wrote home last on the $22 \mathrm{nd}$. Since then very little change has taken place up here. We have a beautiful bird's-eye view of Sebastopol from the camp; it appears a very handsome town, the buildings all very substantial and goodlooking of white stone, but we seem as far off as ever from seeing the interior of them. The pounding match continues with as much vigour as ever on both sides, and with so little apparent effect that it is beginning to lose all interest; however, we are kept in a constant state of excitement by the Russian army in our rear, who are now disagreeably near to us. The day before yesterday was a most deplorable one for our army. ${ }^{1}$ Some

1 Battle of Balaclava. This inaccurate account shows, as Flower himself often pointed out, how little the eye-witnesses were really able to see and understand what was going on until they read the news afterwards in the Times. 
batteries beyond Balaclava, put up to protect the rear of our position, mounted with English guns but manned by Turks, were surprised by the Russians early in the morning and the guns taken; the Light Brigade of Cavalry (4th and $13^{\text {th }}$ Light Dragoons, 8th and 9 th Hussars, and $I 7$ th Lancers) were ordered to charge the enemy and drive them out. This they did gallantly, but, pursuing too far, fell into a sort of ambush between three Russian batteries and were literally cut to pieces; of the last-named regiment I believe there are scarcely a dozen men left, and the others are said to be nearly as badly off. You will see a fuller account of this disastrous affair in the papers, I suppose. Our division were marched out to the scene of action, though too late to be of any use; the field looked like a second Alma. Yesterday there was another encounter, though it ended more fortunately, a few companies of infantry and artillery having put to flight, with considerable slaughter, a large number of Russians. . . . There are a good many amateurs here, come out to see what is going on; they live comfortably on board ship, and annoy us by turning out clean with immaculate shirt collars and shining boots, reminding us forcibly of Hotspur's friend with the pouncet-box. There is also a lady, wife of a cavalry officer, who rides about and seems to enjoy the sight of powder and death amazingly.-Your very affectionate brother,

W. H. FlOWER.

\section{CaMp NEAR Sebastopol, November 2, 1854 .}

DEAREST Mother-Another month has come round and we are still in the same position, the only change being that the fine summer weather which we had for so long has turned to weather equally fine but intensely cold, especially at night. There is very little of novelty or interest since my last, though we are expecting something more active will be done in a few days. Indeed, if this cold weather continues or increases, as it probably will, we shall hardly be able to go on with the siege operations and tent life. . . There is no news yet of our baggage. Nearly all the other regiments have got theirs, but the Avon most obstinately keeps out of the way. You will just know from this that I am 
alive and quite well so far, and with best love to all at home, am, as always, your very affectionate son,

William Henry Flower.

Camp near Sebastopol,

November 7, 1854 .

MY DEAR Mother-... Since I wrote last we have had some stirring events in the regiment, which I may as well tell you about first. On Sunday last (Gunpowder Plot day) the Russians made a great attack upon us, but were repulsed after a very long and desperate battle. Our regiment is said to have gained great laurels, though they were dearly bought, as the loss was very severe. ${ }^{1}$ The battle, I believe, is to be called "Inkerman," as it took place on heights of that name, not a mile from the camp. I saw very little of it but smoke, having quite enough to do to attend to the wounded, who were brought up to hospital almost as soon as they fell. The continual rattling of musketry and roar of artillery was quite astonishing. . . . The Colonel ${ }^{2}$ is a great loss and very much regretted. Many a man whose wounds I was dressing said, "I don't care for myself, but to think of the poor Colonel." $\mathrm{He}$ was gallantly leading the regiment on to the charge at the time when he fell. Poor Clutterbuck, too, a very fine lad; he was carrying the colours, and, seeing the men falter under the very heavy fire, he unfurled them round his head, calling out, "Come on, Sixty-Third!" and almost the same instant was shot down. It is a very melancholy thing to see men whom one has lived with so long and intimately so fearfully injured or killed. But great as our own immediate loss has been, it has been nearly, if not quite, as much in the other regiments of the division - the General, Sir George Cathcart, killed; BrigadierGeneral Goldie, since dead of wounds; and our Brigadier, Torrens, severely wounded in the chest. Out of thirteen general officers present, eight were killed or wounded; among the latter is Sir George Brown, very severely, I fear,-a loss we can ill

1 Out of sixteen officers of the 63 rd Regiment engaged at Inkerman three were killed and eight wounded.

2 Lieut.-Colonel E. S. T. Swyny. 
afford, as he is a brave old soldier with the energy and courage of a lion. General Strangways, of the Artillery, is also a great loss. On the whole, the "butcher's bill" is more heavy than that at Alma, though the battle will be productive of very little effect, as we were merely maintaining a position, and, I am afraid, will bring us no nearer the end of our woes, viz. the taking of Sebastopol. The loss of our Colonel is greatly felt in the regiment, the more so as his successor is very unpopular, being a great martinet, and having only lately come into the regiment. He had the great bad taste, if it should not be called by a worse name, to assemble the men the morning after the battle where they had fought so bravely, and before the late Colonel was buried, to tell them that they were a most undisciplined, disorderly set, but that now he had the honour to command them he was going to make all sorts of reforms, etc., etc. ... However deficient the medical arrangements might have been at Alma (and they were undoubtedly so), things were done here admirably, and I think that, considering the circumstances, no one can find fault. The ambulance waggons (which had not arrived in time for Alma) were most useful, and it is almost unprecedented that before night the whole of the wounded (nearly 600 in this division alone) were removed from the field, deposited in their respective hospitals, and (I can answer for all those in our own regiment at least) their wounds attended to.

We had great work; in fact, I have not had a minute to spare since, and am now obliged to write in a great hurry. I am sanguinary-minded enough rather to have enjoyed this last two days, especially as I got the opportunity of performing several amputations which, I am happy to say, went off with great éclat and complete success. At all events, wounds are more satisfactory to treat than sickness, where so little can be done with many lying in tents without proper warmth or diet or anything requisite for their recovery; under such circumstances medicines can be of very little good. We shall be relieved of the greater part of this sudden influx of work to-morrow, as the wounded are going down to Balaclava on their way to Scutari. . . .

The heads of the medical departments do not seem to have 
sufficient authority or weight with the generals to carry out what they wish (this is, of course, much their own fault), there being rather a disposition in the British army to snub the doctors and not give them fair-play. ${ }^{I}$ Dr. Hall seems, as far as I have seen of him, a clever and straightforward man, quite the best who could have been selected. In spite of his advice, we give chloroform in every operation in this regiment, with the best possible results.

I wish I had time to write more fully.-Ever your affectionate son, with best love to all,

W. H. FLOWER.

Crimea, Wednesday, November 22, I854.

DeAREST Mother-Again the old well-known thin envelopes and the old paper $;^{2}$ this tells a tale of happiness or at least comfort to me; at length we have got our baggage and are able to change our clothes and keep ourselves a little decent and clean again after more than two months of wretched privation.

The other day (Tuesday week), while we were comfortably asleep just about daylight, there was a crash and a flop of wet canvas, and we woke and found ourselves in the open air, exposed to a most bitter north wind, or rather hurricane and sleeting snow. Our first impulse was to look at each other and burst out laughing, the situation appeared so sublimely ridiculous, especially as all the other tents around were one by one sharing the same fate, exposing the inhabitants within in the most merciless way; but as all our few articles of furniture were being scattered by the wind or spoilt by the wet, matters became serious and we had to get up to see what was to be done, but we found we could do nothing, the wind blowing so as to prevent the possibility of putting up the tent, so we stowed ourselves away as best we could. O'Dell and I got into a sort of hovel of turf, covered over with boughs (which soon blew off), and wrapped in all the blankets we could muster, lay and awaited

Older army surgeons learnt nothing and objected to new methods.

2 This was the first letter written on ordinary writing-paper since September 16. The others were written on odd scraps, old envelopes, etc. 
our fate, expecting to be frozen to death. ${ }^{1}$ Here we had to stop till the following morning, when the tents were able to be put up again, and a fine day restored all to its wonted serenity. . The sufferings of the men were very great, especially of the poor wretches in hospital, five of whom died; this was increased by the stoppage of food and rum, which could not be issued on account of the weather. ...

The siege drags its slow length along, and we seem in for a regular winter campaign, which is considered a great sell and is talked of with very long faces, especially if such little episodes as that of Tuesday last are to occur again. Then there will be the difficulty of getting up provisions from Balaclava now the roads are so dreadfully heavy and the storms on the sea wrecking the ships. But it will not do to anticipate evils, though it is rather amusing to read the Times articles about the beginning of the campaign, where they abuse the Russians and Prince Menschikoff, and make out that everything they did were blunders, and that Sebastopol was so easy to be taken; whereas we find them most respectable opponents. The defence has certainly been successfully conducted so far, and it is strange that, with our boasted civilisation and progress in the arts and sciences, our only superiority over the Russians seems to be in the greater courage and mettle of the men, while in those very departments in which the most civilised nation should excel, they beat us, as in their artillery, engineering, and in the arming, clothing, and equipment of the men. On the whole, I have a great respect for Russia and the Russians from the Czar downwards, and I think this war is decidedly one against civilisation and progress. What would the Crimea have been if left to its original Tartar possessors or given over to the Turks? Where would have been such magnificent towns as Sebastopol and Simferopol are said to be, the beautiful and well-furnished country houses, comfortable villages, vineyards, etc., but for the Russian Emperor? And now, by spreading the horrors of war, we are stopping and

1 Such a dreary scene as the camp presented this evening I never saw, and such a night as we passed. Myself sick with feverish attack and feet frost-bitten. (Diary, November I4, I854.) 
destroying all this. Though the Czar may be a great despot, yet I think, throughout this semi-barbarous country, Russian influence is for good, and unless we can supply a better (which the Turkish influence certainly is not) it is a pity to destroy it. . . I I am your very affectionate son,

William Henry Flower.

\section{Camp above Sebastopol,} December I, 1854 .

Dear Father-Your letter of October 29 arrived only the day before yesterday. It was a very great pleasure to me to hear from you. I know that you have so many other things to do that you cannot often spare time to write, but the Mother is such an excellent correspondent that her letters seem to come from you both. I rejoice to hear of your being all well and of all you say, except your constant anxiety about me; the thought of that amid all the hardships, I may say miseries, of this life, is the only one that really troubles me; I want to think of you always happy and cheerful and comfortable, but then I know and picture to myself the "all-absorbing anxiety" and alarm which prevents this, and of which $I$ alone am the cause, and I feel myself a culprit. Strange that your trouble should be me out here and mine be you at home; but so I suppose it is with all similarly circumstanced. I often think now of your backwoods life and the roughs and privations you must have gone through, to which, I daresay, these are trifles, but still there are hardish times on the heights above Sebastopol, better to look back upon than to have about one ; still I look steadily forward with perfect confidence to scrambling out of them and lighting on my legs safe and sound again, whatever may become of the rest, for we seem to be in a precious mess somehow or other.

War is not all such plain-sailing work as it seemed at the outset; at all events it is a game at which two can play, as the Russians have shown. Our position here seems daily becoming more critical, not that it seems probable that the enemy can ever drive us out of it, as its natural and artificial strength seems capable of resisting any attack, but the difficulty of keeping men alive and in working order when they are surrounded by every 
CHAP.

circumstance that tends to an opposite result appears insurmountable. The reinforcements that are sent from England go a very little way even towards keeping up the present effective state. These continued rains (it is pouring now, and nearly always, as hard as it can) are most trying to the men, and their work becomes harder as their numbers diminish by sickness. They have to be out all night in the trenches, often two nights out of three, and very seldom get two clear nights in camp; their food and grog is served out very irregularly now when it is wanted most, and as the bad weather continues we are always in dread of a total cessation of supplies. To show how little the nominal force has to do with the real effective condition of an army, this regiment which brought out over 1000 men could scarcely number 300 now fit for action, and I believe it is the same with all the others. ${ }^{1}$

The horses suffer as much as the men; it is miserable to see the poor animals picketed outside the tents with nothing to protect them from the wind and rain, and sometimes no forage for three days on end; I can see a group of ponies from my tentdoor standing with their backs to the wind and their feet all gathered together, surrounded by a sea of mud, looking images of resignation and misery. That reminds me of your inquiries after the fate of my rough little Cossack; it was the common one of them here; he was stolen one night while I was on board ship, and I daresay he has changed hands a dozen times since.

I suppose the Russians, who are in the field in our rear, are as , badly off as ourselves, or worse, as they have further to convey their provisions, etc. ; it is a consolation to think that this may be the case. I hope our alliance with the French will last; they are fine fellows, true soldiers every inch, so active, intelligent, and quick and always cheerful; very different to the stupid, hulking-looking creatures many of ours, especially the recruits, are; but the courage of the English before the enemy is quite astonishing. I do not think it so much courage exactly as sense of duty which causes a most total disregard of life and everything

1 The total number of officers and men of the 63 rd Regiment who were killed, died of wounds, or were invalided home during the Crimean campaign was 947. See History of the 63rd West Suffolk Reginent, p. 167. 
else. I really do not think there is any nation like them in this respect; they have certainly kept up the old character nobly in this campaign, that perfect steadiness under the heaviest fire, either when standing still or advancing to the charge.

It seems a great pity that the Fleet is commanded by such an old muff as Dundas, while there is such a man as Lyons, who seems one of the old Nelson sort, and is almost worshipped by the men, but being only second in command, his hands are much tied. . . .

You think that the most horrid part of this must be after a battle, when the surgeons are at work. Now by a strange, and perhaps happy, difference of taste this is just the time when I am in my glory; it is worth weeks of discomfort and inaction, and only comes too seldom; in fact, the battle of Inkerman and stray cases during the siege are the only surgery we have had. At Alma the regiment was suffering so fearfully from the cholera, nearly a hundred sick at once, that we had enough to do with them, but as soon as I could get a little time to spare (about the middle of the day after the battle) I went down to the General Hospital to see what was going on. I found a number of low buildings surrounding a yard; on nearly every part of the floor and ground were lying men, English and Russians, with every conceivable sort of horrid wound, and others were being brought in and laid wherever they could find room. In a small hovel a man was having his leg cut off while lying on a heap of straw on the ground, the surgeon and his assistant nearly breaking their backs as they did it. A surgeon in a regiment I knew a little of, seeing me, asked me to assist at several operations which had been waiting some time as he could not get any help. To this I gladly assented, but as we were going to begin, one of the DeputyInspectors came up and said he wanted an assistant surgeon to go with some wounded men down to the ships, and that I must go, and the operations must wait; so, accordingly, I had to trudge off by the side of half a dozen araba waggons filled with wounded men three miles down to the beach, an occupation in which I could not be of the slightest earthly use either to the wounded men or any one else, as when they got down there the naval assistant surgeons were ready to receive them. I found 
several other assistant surgeons who had been performing the same useless pilgrimage, which in some measure accounted for the want of efficient medical aid. As I turned homewards (resolved carefully to avoid the General Hospital and all the Deputy-Inspectors for the future) I fell into conversation with a French officer, who asked if I would like to see their "Ambulance," which he said we would pass close to; so I went in with him, and soon introduced myself to one of the doctors, of whom there were eight or nine, all very civil, pleasant men, including the principal one. They took me round and showed me everything, the waggons beautifully fitted with splendid sets of surgical instruments. There was not a patient left, except a few Russians, the rest having all been taken on board; they regretted that most of their operating was finished, but if I would wait there was a Russian to have his leg off and they would do it at once. Accordingly, the patient was brought into a tent regularly fitted like a Paris or a London operating theatre, with proper table and everything convenient, and the amputation was done with as much neatness and propriety as it could be at home. After thanking them for their kindness, I found my way back to our camp, certainly most favourably impressed with the French arrangements, especially in comparison with ours. . . .

I must soon close this rambling letter. I have applied to be sent down to Balaclava for a week or so to get away from this cold and damp, which has given me one or two slight feverish attacks and makes me feel rheumatic, but a couple of days' fine weather would make me all right.

Now, my dear father, again thanking you for your letter, and with my best love to all, ever your affectionate son,

William Henry Flower.

Though writing cheerfully to his father and, so as not to alarm him, making light of his "one or two slight feverish attacks," Flower was, when he wrote, and had been for the past six days, laid up in his tent with both feet frost-bitten and a severe 
fever. On the and December he was recommended fourteen days' leave to Balaclava; the order was signed by the Surgeon, but had to be sent round to be countersigned by the Staff-Surgeon of the Division, the Commanding Officer of the Regiment, the General Commanding the Division, and the Adjutant-General at Headquarters. On this round the order somehow got lost, so Flower did not get his leave. Meantime, with the continual cold and rain, his health was getting worse, and on the recommendation of a Medical Board he was given "leave of absence to proceed to England for the recovery of his health," and sailed on board the Victoria from the Crimea on the 12 th December.

From his own letters we learn nothing of his work under fire, but from other sources we hear how that before Sebastopol he went from the shelter of the camp in broad daylight across the shot-swept ground to the assistance of some of the wounded men in one of the forward trenches, and how, at Inkerman, he and some other surgeons "made themselves remarked for their coolness and devotedness to their professional duties; nothing deterred by a hot fire, they pressed on, regardless of danger, to give their services to the wounded." 1

On the I $5^{\text {th }}$ December the Victoria arrived in the Bosphorus, in which neighbourhood he had to pass a month before he could get a passage to England.

1 History of the 63rd West Suffolk Regiment, p. I 6. 
Constantinople, December 28, 1854 .

Dearest Mother-. . The transport service does not seem well managed, as there are numbers of steamers waiting here doing nothing, and yet they cannot get enough for the exigencies of the war. They come down here full of sick from Balaclava, have to wait four or five days before the sick are landed, then remain doing nothing for a week or two, then perhaps are filled with convalescent patients, then wait four or five more days, then go back to Balaclava or England, as the case may be; they might have made a dozen journeys in the time.

I went over the hospital at Scutari yesterday. Whatever may have been the sufferings and neglect of the patients there at first, now the cleanliness, comfort, and almost luxury they live in surpasses that of any hospital at home. It must be a Paradise after the camp. I was much pleased to find a man whose leg I cut off after the battle of Inkerman and to hear that he was going on very well indeed. ...

At length he got a passage on the Harbinger (auxiliary screw steamer), and after a long and rather rough passage landed at Southampton on the $5^{\text {th }}$ February I 855 . 


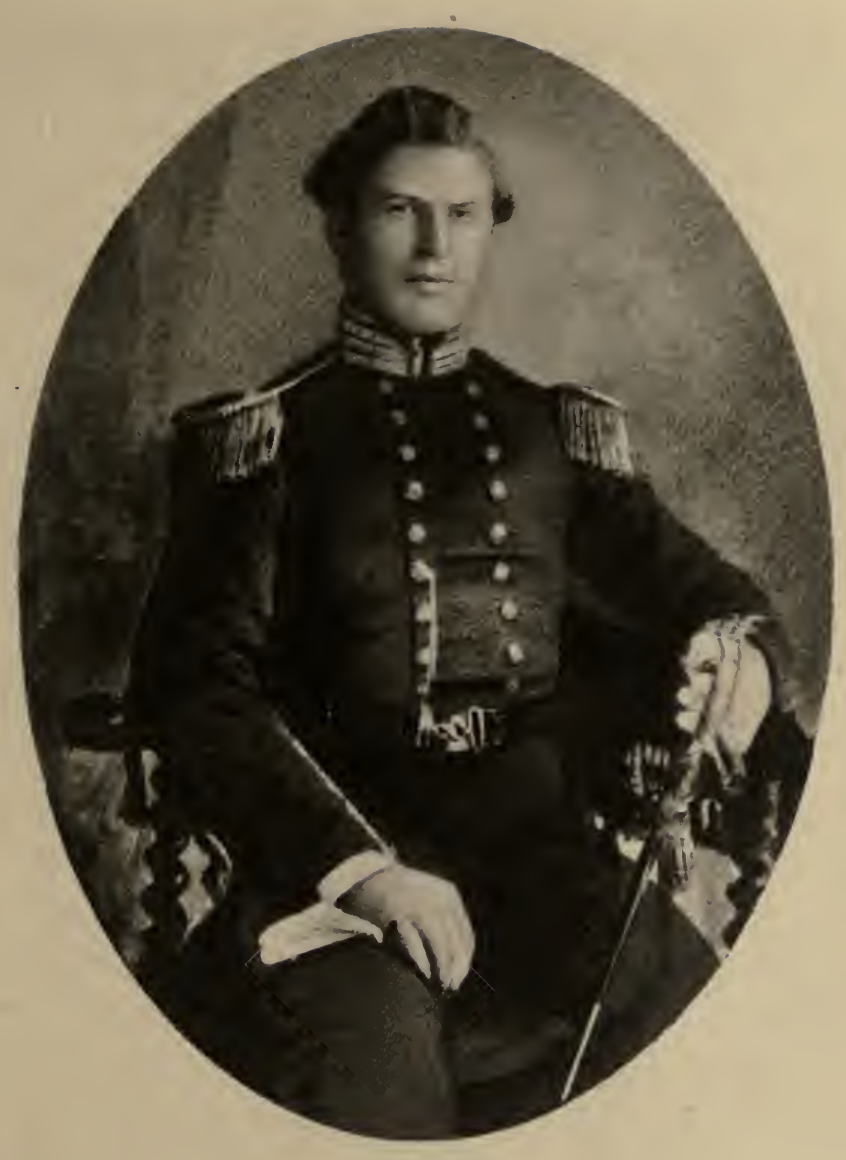

Tlilliam Menry Flower, 63: Requiment.

Photogruphed by his Ulother, on his return frum the "irimen 



\section{CHAPTER III}

MARRIAGE AND EARLY PROFESSIONAL LIFE

For his services as Assistant-Surgeon to the 63 rd Regiment during the war, Flower received the medal with clasps for Alma, Inkerman, Balaclava, and Sebastopol direct from the Queen's hand, as well as the Turkish medal later. Recent experience of the devoted service of medical men of all ages and position who volunteered for the South African War has familiarised us also with their return to active civil life and the resumption of their profession in London. Flower's position was an analogous one. After his health had recovered from the temporary breakdown caused by the hardships of the campaign, he resigned the army, and in 1857 took the diploma of F.R.C.S. ${ }^{1}$ In 1859 he was appointed to the office of Assistant-Surgeon to the Middlesex Hospital, to which duties were added those of Lecturer upon Anatomy and Curator of the Anatomical Museum of the Hospital.

But his work at this time was not identified

1 On January 3,1856 , he notes, "I took my first fee, $£ \mathrm{I}: \mathrm{Is}$, , from Uncle John Greaves for curing his finger." 
with the activities by which he won fame later. $\mathrm{He}$ was a rising young surgeon, and while specialising from the speculative side in Comparative Anatomy, was marking the beginning of what promised to be a brilliant career in the active exercise of his profession. He acquired a reputation as a successful operator, especially in affections of the eye. $\mathrm{He}$ had, as might be expected from his physique and equable temperament, the steady and yet fine hand necessary for such delicate work. Before five years had passed, and when it became a question whether he should divert his energies from surgery to pure science, he was assured by one of those most competent to judge, that he "could make more thousands as a surgeon than he ever would hundreds as a man of science." But the accumulation of money had no great attraction for Flower at any time as the chief end in life. At this time he published some original observations on the Injuries of the Upper Extremities, in Holmes' System of Surgery, in which he incorporated his own researches on the various dislocations of the shoulder joint. His diagrams illustrating certain of these became standard illustrations in text-books, and are familiar to most of those who have studied injuries to bones.

While continuing his regular work at the Hospital he gave effect to some of the impressions left on him by the war. He had learnt by experience that military surgery was ill-taught in the United Kingdom. Men suffering from frightful injuries, 
improperly treated, were still common objects in the country. In February 1859 he delivered at the United Service Institution a lecture on the importance of a knowledge of the elements of practical surgery to naval and military officers. By these elements he meant not so much a rough knowledge of anatomy, but such matters as are now called "first aid," which have now become part of the knowledge not only of officers, but of many privates, and are embodied in military textbooks.

Here, for instance, is what was then deemed an enlightened suggestion for carrying a badly wounded man, made by a general of the day. "A single pole, eight or nine feet in length, a branch of a tree, an oar, or anything of the sort that can be procured, is laid down beside the wounded man, who is lashed firmly to it from head to foot with handkerchiefs, belts, clothes, or blankets torn in strips. It is then lifted up and carried on the shoulders of two men, or may even be dragged for some distance, with one end resting on the ground, by a single man!" Flower showed that with the progress in the art of destruction there had been a corresponding advance in the means adopted for the preservation of wounded men from the after effects of their injuries, and from the accidents inseparable from war. He then showed how bleeding, burns, frost-bite, exposed wounds and the like might be treated, or prevented from becoming worse until the surgeon was at hand, and gave 
a number of practical examples and advice as to what can be done to preserve health in campaigns, in exploration, and in surveying distant countries.

It was while on a walking tour in Wales during his early student days that Sir William met the family of Admiral W. H. Smyth, whose youngest daughter, then only fifteen years of age, was destined afterwards to become his wife. The Admiral, who, among other rigorous rules of life, held that no man could need more than five hours of sleep, and only took four himself during his naval career, was favourably impressed by learning that the tall young man whom they met at a dance at Tanyralt proposed only to change his clothes, and then to walk twenty miles across the hills to join the coach at Carnarvon.

The acquaintance was continued, and before long Flower found himself a guest at St. John's Lodge (in the village of Stone, in the Vale of Aylesbury), where Admiral Smyth carried on his astronomical observations, researches, and publications in the midst of his family, and surrounded by the ordinary social life of the country.

There Flower found an atmosphere of scientific and intellectual activity of the most congenial kind, in which every member of the family took an interest and in some degree shared. There was plenty of time for amusements too, but the environment was certainly of an unusually vigorous character, both mentally and physically. The eldest son, afterwards 
Sir Warington Smyth, the celebrated geologist and mineralogist, had rowed in the Cambridge "eight" which defeated Oxford in I839. Another, Charles Piazzi Smyth, was for many years Astronomer-Royal for Scotland, and well known for his researches in the Great Pyramid; a third is General Sir Henry Augustus Smyth, K.C.M.G., sometime Governor of Malta; whilst a daughter, Henrietta, married the Rev. Baden Powell, Savilian Professor of Geometry in the University of Oxford, and counted among her children Sir George Smyth Baden-Powell, M.P., and General Robert Stephenson Smyth Baden-Powell, C.B. Another daughter, Ellen, became the wife of Captain $\mathrm{H}$. Toynbee, who has worked so devotedly in the cause of seamen, especially in helping to establish Sailors' Homes.

Admiral Smyth, who claimed descent from Captain John Smyth, the founder of Virginia, married at the conclusion of the great war with France, at Messina in Sicily in 1815, Annarella, the only child of Mr. Thomas Warington, English Consul at Naples, a lady as remarkable for her beauty and accomplishments as for her charming disposition. ${ }^{1}$

As an instance of the touch which the present may have with the past, it may be mentioned that Mrs. Smyth had been present, as a little girl, and figuring as the only lady there, at a dinner given by her father to Nelson and his captains after the

1 She was an accomplished artist, and bequeathed the taste to many of her children and grandchildren. 
battle of the Nile. One of them gave her a kiss, which she did not altogether approve of, and Nelson said, "You must not mind, my dear. His name is Hardy, and he is the captain of the Audacious."

Sir Charles Lyell says of her and her husband in his diary :-

Captain Smyth called, and said his letters from France have disgusted him with the manner in which the eminent scientific men have thrown up their pursuits and turned place-hunters, even Arago. Smyth has an ardent love for science for its own sake, in which his wife sympathises most strongly, and I know no people who have less worldly-mindedness or low ambition or more real happiness and contentment with a small income.

And again later:-

When I called yesterday on Mrs. Smyth I caught her making abstracts from La Place's Astronomy of those facts and speculations which could be made intelligible to persons not mathematicians. Her selection is so beautiful and striking that when it is finished I shall get a copy.

That many-sided scientific sailor Admiral Smyth, after much active service in Indian, Chinese, and Australian waters in the great naval wars of the time, had made charts of the Mediterranean Sea, charts which are the working basis of those now in use, and had been President of the Royal Astronomical Society in $1845-6$. He was also one of the founders of the Royal Geographical Society and of the United Service Institution, and Vice-president and Foreign Secretary of the Royal Society, Vice-president and Director of the 
Society of Antiquaries, and an honorary or corresponding member of at least three-fourths of the scientific and literary societies of the world. $\mathrm{He}$ was also a distinguished numismatist, and an indefatigable and prolific writer. His children, when quite young, used to help him in any way in which they could, cutting new books, and even in proofreading, when they were paid at the rate of a "penny for four," for any mistakes in spelling, misplaced letters, etc.

Flower's work as a surgeon steadily increased, and on April 15, 1858, his marriage took place at Stone Church, he being then in his twenty-seventh year, and his bride just twenty-three. "On the

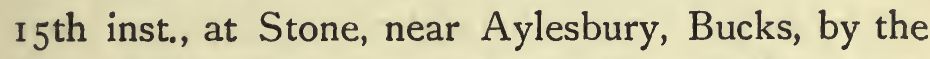
Rev. Baden Powell, brother-in-law of the bride, assisted by the Rev. W. Airy, Vicar of Keysoe, and the Rev. J. B. Reade, Vicar of Stone, William Henry Flower, second son of E. F. Flower, Esq., of the Hill, Stratford-upon-Avon, to Georgiana Rosetta, youngest daughter of Rear-Admiral Smyth, K.S.F., D.C.L., and of St. John's Lodge, Stone." So runs the Times paragraph. Flower and his bride left for Dover, and spent the honeymoon in Flanders, Brussels, Louvain, and thence went up the Rhine, the first of a series of journeys abroad together which formed an almost annual pleasure for very many years. They repeated the honeymoon journey after their silver wedding, twenty-five years later, taking two of their children with them. 
Lady Flower says of this time, "One of the great pleasures during this, our first journey together, was the beauty of the spring flowers abroad, where all the fruit-trees were in blossom, and listening to the birds in full song. My husband knew the notes of all, and delighted in teaching me to learn the different sounds or to identify their flight and movements. Our visits to the old historic towns, in which his interest in architecture, history, and the paintings of the old masters had full play, were equally delightful. His appreciation of these subjects remained and grew all his life, side by side with his master passion for science."

Thus began the new era. Flower wrote of his marriage as "the most important and happiest event of my life," a feeling to which he remained constant to the last, and to which a faithful and touching tribute will be found in every line of the last chapter of this memoir. ${ }^{1}$

The dedication of his last book, the Essays on Museums, published in 1898 , is written in the following words :-

To her who for forty years has been my never-failing counsellor and support in all difficulties and perplexities this collection of fugitive thoughts upon subjects closely associated with the greater part of our joint life's work is lovingly dedicated.

It was on May 19, 1858, that they came back to England, and arrived at I 5 Queen Anne Street,

1 By Lady Flower. 


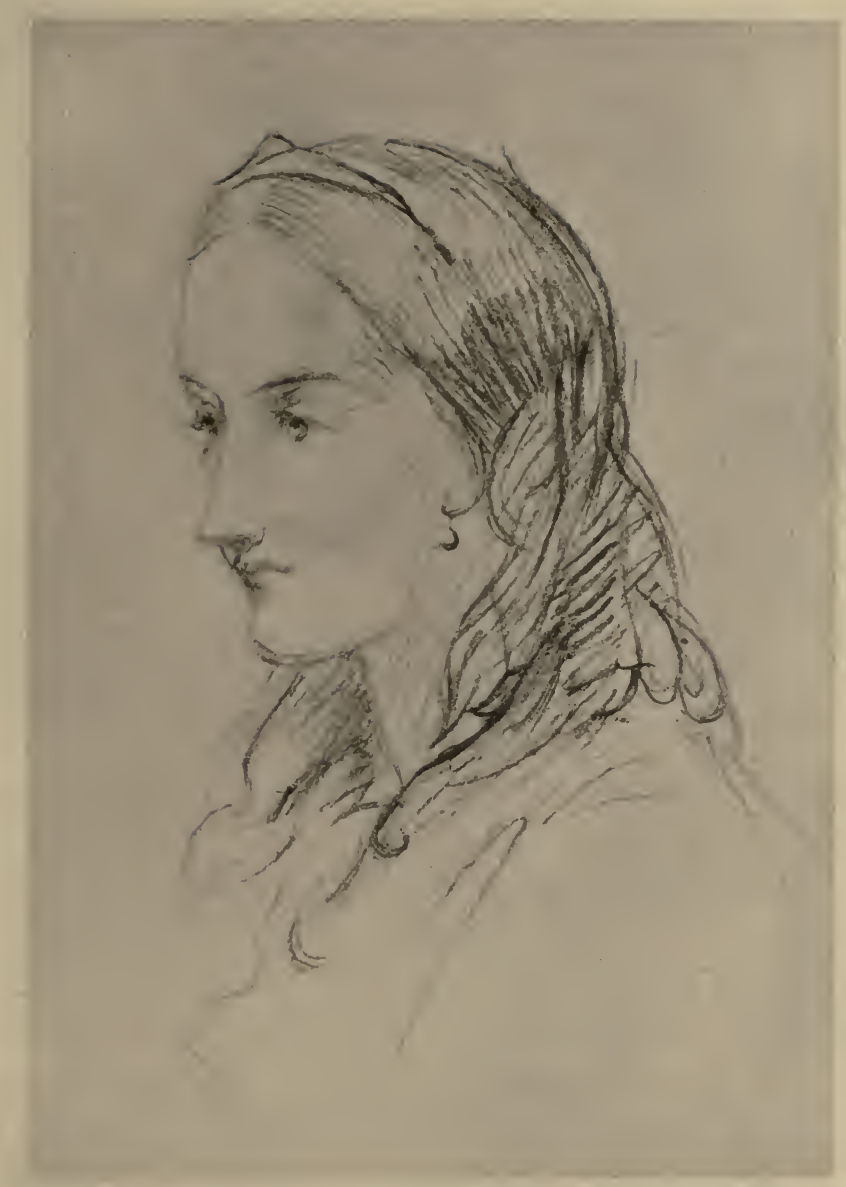

Georyiana Rosella Thower, 1859.

From a drauring by Why Sessen afterwarts uife of Sir Chartes tewton. 

Cavendish Square, which had been purchased for them by Flower's father, and which was to be his home until his appointment to the Hunterian Museum.

On May 22, I860, their first child was born-a son-who was christened in Stone Church, Arthur Smyth Flower. Flower maintained that this was the "proper scientific way of naming children." There might be other "Arthur Flowers," but by placing the name of the mother before the name of the father the chances of confusion were rendered less, while at the same time information was conveyed as to the parentage on both sides.

While holding the offices of Assistant-Surgeon to the Hospital and Lecturer on Comparative Anatomy his work entitled Diagrams of the Nerves of the Human Body was completed and published. It was translated into French in I888, and into Italian in I890. It was received with warm commendation by the profession. The diagrams were a successful effort, on what was Flower's invariable plan later, to let the eye see, as easily and comprehensively as possible, what verbal memory finds it difficult to recall. The distribution of the nerves was so clearly displayed as to be a useful guide and reminder both to the expert and the student. In June 1860 his brother-in-law, the Rev. Professor Baden Powell, died. His relations with Flower had been of the most cordial nature. His ability and high character, as well as his liberal attitude towards 
the scientific discoveries of the day, were of the kind which Flower appreciated in a Churchman who was also a man of science, and his death was subject for sincere regret.

Nor did Flower confine himself to lamenting the loss of a friend endeared to him alike by judgment and personal regard. No one of the writers in Essays and Reviews had been more consistently misrepresented than Baden Powell. His dislike of violence in speech or print did not let him follow the example of the critics by an equally violent defence. But when an eminent Churchman allowed himself to say that Mr. Baden Powell had died " without any ministrations of religion," Flower, who was with him for the last three days and nights of his life, just as later he spent the last of Dean Stanley's nights on earth by his bedside, wrote to say that "as long as he was able Mr. Baden Powell regularly attended divine service at St. Andrew's, Wells Street, and received the Holy Communion, and read the Liturgy of the Church of England with his family." Flower stated that "never did one single expression escape him that did not tell of peace, of resignation to God's will, and of faith in the religion in which he had been brought up, in which he had always lived, and in which he was then dying." He also wrote a short obituary notice of him which throws a light on Flower's own attitude at a time when many less clear heads were so seriously affected by the new discoveries 
that they could not reconcile them with the foundation of old beliefs. He said of Baden Powell :-

The congregations of several of the principal London churches had the opportunity of hearing his sermons, which were remarkable for the masterly manner in which important Christian truths were enunciated with the clearness and precision of a mathematical demonstration. His principal efforts were to define the limits between the objects of faith and of knowledge, and to show that the progress of modern scientific discovery, although necessitating modifications in many of the still prevailing ideas with which the Christian religion became encrusted in the days of ignorance and superstition, is in no way incompatible with a sincere and practical acceptance of its great and fundamental truths.

The year 186I, which saw the birth of the Flowers' second child, Caroline Mary, on September I 2, proved the last of his professional life as a surgeon.

During the exercise of his profession at the Hospital he had steadily kept up his interests in Comparative Anatomy and Zoology. Besides reading papers before the Zoological Society, he had worked with such freshness and success in the Middlesex Hospital Museum that the general Court of Governors sent to him a resolution, passed unanimously, that "the best thanks of this Court be conveyed to W. H. Flower, Esq., for his eminent services during the past year (I860) as Curator of the Museum of the College." The reports of the Museum Committee stated that "he has manifested no less judgment in the selection of valuable new 
specimens, and no less delicacy of manipulative skill in their preparation and display than in former years. They can add, however, that they have never before had the gratification of reporting such a large addition of new and instructive specimens as was exhibited to them by Mr. Flower to-day. They desire, therefore, to record their especial thanks to him for the zeal which has stimulated and the intelligence which has directed his labours during the past year." In another communication the governors added to their thanks to Flower a word of courteous appreciation of his wife's interest and help in the Museum. There is no profession in which good work is so quickly recognised as in that of surgery and medicine. Flower's extra work in the Hospital Museum of Comparative Anatomy was also much appreciated, and his interests in zoology were well known to the authorities who controlled the great surgical institutions of London. He read several very original papers before the Zoological Society on animal anatomy, attended Huxley's lectures, visited the "Zoo" very frequently, and in one week we find him lecturing to the men in his father's brewery at Stratford-on-Avon on the "Relation of Men to Animals," and also that his paper on the "Brains of the Quadrumana," read before the Zoological Society, had been reprinted in an improved form by the Royal Society. This paper on the "Brains of Monkeys," which was probably inspired by the 
controversy aroused over Darwin's Descent of Man, was destined to bring the writer into public prominence in an interesting manner. For the present let us leave it, where Flower did, in print and ready for use.

It will be clear from the above that Flower had already made a name as a comparative anatomist, a surgeon, a zoologist, and as having new and original views as to the management of museums. The opportunity for further advancement came, in a specially appropriate way, from the leaders of the surgical profession, yet on the lines for which his museum work had shown his particular qualifications. By a happy coincidence the great Corporation of the Royal College of Surgeons possessed one of the best museums of a special kind in England. It contained the collections of John Hunter, with many subsequent additions. It was finely housed, and the Conservator was paid a not illiberal stipend, besides enjoying the use of a good house adjoining the buildings of the Royal College of Surgeons in Lincoln's Inn Fields. The post had been held by Professor Owen, who was also Hunterian Lecturer to the College. Professor Owen resigned the Conservatorship to take up the duties of the new post of Superintendent of Zoology in the British Museum, though he kept the office of Hunterian Lecturer. Dr. Quekett succeeded Owen, and it was his death which caused the post to become vacant. 
Of Flower's life at the time when this occurred Lady Flower writes :-

At the hospital he took the greatest personal interest in the patients, especially in the poor patients, as well as in the purely scientific work of his Anatomical lectureship and Anatomical Museum. His interests in zoology also steadily increased. But in regard to his surgical work he felt so keenly for the patients in the wards that he would lie awake at night considering whether everything was being done that was possible for them. He would be called to the hospital at any hour of the night in cases of danger, and he always felt more particularly anxious when the cases were those of poor people, the fathers or mothers of young children, to whom the death of the parents must always be almost irreparable. Altogether, I think he preferred practising among the poor rather than among the rich, and he had an unprofessional objection to taking fees! All this prepared him for giving up practice, and when the opening came he had little doubt as to making the application.

His father, who was devoted to his clever and scientific son, quite shared that view. He wrote :-

Both of us (i.e. Mrs. Flower and himself) came to the conclusion at once, without consultation, that it will be a happy thing if you can obtain the appointment. It places you in a high and honourable position at once, suited to your peculiar tastes and talents, which is rarely attainable at any time of life. . . . I hope, my dear Will, never to be in circumstances during my life to do less for you than at present, and afterwards I trust that you will have something more. Taking all sides of your position into view, we have no doubt in our minds about the matter.

It will be seen from his father's letter and reference to his son's prospects that in following the natural bent of his talents Flower was doing no injustice to 
his family, even had he not been destined to reach later a post of greater emolument. But his case is an instance of the favourable effect, as regards the choice of a life's work, which a considerable independence in prospect, and the encouragement which it gives, may have on a scientific career. There were nearly fifty candidates for the post of Curator to the Hunterian Museum, of whom Flower was the youngest. But he received the warm support not only of leaders of the medical profession, like his friend James Paget, but of men of pure science, and especially of Professor Huxley. On Thursday, December 19, I861, he was unanimously elected by the Council of the Royal College of Surgeons to be Conservator of the Museum, and received notice to attend on the following Tuesday, which was Christmas Eve, to be formally admitted to the office. On New Year's Day I862 he started from Queen Anne Street to take up his new post, in which he remained engaged successfully and happily for the next twenty-two years. 


\section{CHAPTER IV}

LIFE IN LINCOLN'S INN FIELDS-THE HUNTERIAN MUSEUM

In the Museum of the Royal College of Surgeons Flower has left his impress in such clear and substantive form that it almost tells its own story. To the specialist it speaks directly. But as the originator of this luminous order himself said, in his first address when appointed to succeed Huxley as Hunterian Professor, that he must be, and intended to act, as the "mouthpiece of his specimens," so, while they tell their own story and uses, they cannot tell the story of what Flower did and how he did it. The writer must therefore endeavour to do this, aided by the opportunities afforded of seeing his work by Professor Stewart, his successor, the present Conservator, and by some of those who were assistants in the Museum at the time, more especially Mr. W. Pearson. ${ }^{1}$

1 Mr. J. W. Clark, Registrary of Cambridge University, who was engaged in the arrangement of the New Museum at Cambridge, constantly saw Flower during his Conservatorship, and has kindly given much information of a peculiarly useful kind. 
Every institution like the Hunterian Museum has its eras and phases of development, conditioned partly by the limits of knowledge at the time, partly by the particular branches in which work is going on most keenly at the moment, and what in less serious pursuits would be called the "fashion" of the day. The particular sphere in which the head of the Museum more especially shines and is interested will also naturally come to the front during the period of his charge. Sir William's immediate predecessor, Mr. Quekett, was a very eminent microscopist, and devoted to his work; but he only held the appointment for five years. ${ }^{1}$

Sir Richard, then Professor Owen, who had previously controlled the fortunes of the Museum, was by bent and acquirements an osteologist and palæontologist, but except in strictly popular lectures appealed to the scientific public mainly.

Flower was in feeling somewhat democratic and very practical. As a surgeon he belonged by position and inclination to a progressive science; and though he relinquished the active practice of that art on his appointment to the charge of John Hunter's Museum, he steadily addressed himself to providing material for its advancement, and to arranging this in such a form as might shorten the labour, and stimulate rather than weary the brain of all earnest workers in the field. To attain this end he deemed no thought too continuous and

1 His name and memory are preserved by the Quekett Microscopical Club. 
no detail unessential. The invention of movable type for printing, as the result of a clear aim at a principle and great object, benefited the whole world by one mechanical aid to knowledge. Flower determined that in future museums Nature itself should be printed in movable type and illustrate its own story, subject only to the intervention of man as Naturae minister et interpres. In the chambers and galleries in Lincoln's Inn Fields, as he found them, the skeletons were the books, the bones the pages, and the "preparations" of particular parts the illustrations; but it was a library which needed almost re-creating. To begin with, the "books" were inaccessible and the "pages" could not be turned. The galleries and cases were filled with the frames of the mammalia, from men to mammoths, and from mammoths to mice. But the larger books were out of reach. The skeletons stood on high stands, and no one could compare the skull or the bones of one animal with those of another unless a pair of steps were available. The skeletons were also rigid, all the parts being fastened together. Thus, at a time when comparative anatomy was engaging earnest attention, there were few or no facilities even for looking first at a part in one species and laying it beside a corresponding part in another, and much that required examination was practically out of sight. One of the earlier improvements made by the new Conservator was to reduce the height of the stands to as low as six inches or a foot, so that 
in every case the specimens were easily seen and examined. As one visitor in the old days remarked, "Before I could only look up at them on their pedestals; now I feel that I could even converse with them." But even so there was no means of examining the portions of the frame separately. To make this possible they were re-set, so that each bone could be detached, examined, and replaced. It became at once possible to detach the shoulder of an antelope, for example, in order to compare or contrast it with that of a horse, or of a swimming animal, or a burrowing animal, and by merely handling the parts of the skeleton, learners were enabled to gain a truer knowledge of facts as a basis for theory.

The "point of view" always limits men's knowledge of anatomy as well as of other things, and as there are many people who cannot readily recognise a map of India or Scotland if presented to them upside down or sideways, so it would be quite possible for students of the shape of bones, muscles, or ligaments to make mistakes about "the wrong side of them," i.e. the side which was not commonly presented to them in specimens. Flower took this into consideration, and was at the utmost pains to let students learn all sides, and so to get true views without ever forming the erroneous ones which a stereotyped aspect of presentation naturally causes. He knew that in what forms the basis of the medical art, book-learning alone was insufficient, but that 
the mechanical difficulties of supplementing it had not yet been overcome. To give an instance; his interest in the anatomy of the horse was well known, and he was appointed examiner to the Veterinary College. He asked one of the candidates in a viva voce examination the places of certain principal nerves, questions which were all answered correctly. So were the subsequent queries as to the terminations of the nerves. He then asked through what route a certain nerve passed from one point to the other. This also was correctly answered, the reply being that it went through a certain "foramen" or hole in a bone. All this was known from a careful and conscientious study of books; but Flower, anxious to feel certain as to the state of knowledge of the examinee, asked him kindly to point out the place on the skeleton. This he was quite unable to do. From that time Flower was more than ever convinced that his theory of the work that lay before him was the right one.

$\mathrm{He}$ developed it on principles which are now almost universal and recognised, but which were then new and original, and as unexpected as they were welcome. Instead of sending the learners round to compare parts of whole structures, he resolved to illustrate particular parts by separating them from the whole, and making a complete series devoted to each part in turn, showing the modifications to meet particular needs, and the adaptations and changes in the same member or organ, by 
development or suppression, as the case might be. We see the system in the highest degree of perfection reached at the time of writing in the Central Hall of the Natural History Museum, where the range is wider than at the Hunterian Museum. But the idea of the work at Lincoln's Inn Fields is equally good; its execution is in many cases not inferior, and from the fact of its being a practical school of anatomy, the collection of preparations of the softer parts, such as muscles, ligaments, and interior organs, is naturally much larger. This, it should be noted, was begun, put in hand, and rapidly completed more than forty years ago. ${ }^{1}$

The first of the series were the bones of "hands" of every kind, showing the extremities of the front limbs of all the existing mammalia and of fossil species then, or from time to time, discovered.

Some of the very first specimens to begin the series were prepared by Flower himself. But though he was an elegant worker in this department, he mainly confined himself to initiating and explaining what he wished done. The practical work was in the hands of very able expert assistants, whose skill he thoroughly appreciated. Among these were Professor Pettigrew, Dr. Murie, Dr. Alban Doran; and Dr. J. G. Garson.2

An instance of the patient getting out of minute details of structure for comparison is to be seen in 
the centre of the south gallery of the central room of the Museum. Every mammal, from man downwards, has three very small bones in the ear, as delicate as the machinery of a watch, and, like the machinery of a watch, worked by springs and levers. As the membranes are very sensitive, the whole apparatus is perhaps more comparable to the mechanism of an aneroid barometer. But its delicacy can be guessed. The three bones are called the hammer, the anvil, and the stirrup, and in man the stirrup bone is about the size of the letter $\mathrm{A}$ in the type here used. Sometimes two of these bones become united. But they are a very interesting and constant feature in the mammalia. All of these bones are set out in small round boxes on a black ground, from the ear bones of the whales to those of the smallest shrew, mice, and jerboas. The work was done by Dr. Alban Doran.

Passing round these galleries the visitor of to-day may read the story of Flower's work there in its sequence both of logic and of time. What he does not necessarily gather is the novelty and originality of this at the time when it was done. It was practically the provision of a new and synoptic work of graphic reference. The development and difference of the outer and inner skeletons, the various joints, and their modifications in the whole mammalian race, the ligaments which hold up and tie the parts together, the muscles which work the joints, the organs of sense which suggest when 
this shall be done, the brain which receives the news, the nerves which transmit the message, all these were selected, graded, and exquisitely prepared to be set before the new generation of students. To give them one and all the means to acquire exact knowledge, by seeing the train of evolution of every part, Flower applied the same process of selection to every important factor in the mammalian frame. No order was omitted from these synoptic pictures. The whales, seals, primates, carnivora, deer, horses, antelopes, rodents, edentata, and others all took their due place in the line. Contemporaneous discoveries of new fossil mammals made an interesting addition.

He next turned his attention to what are known as "wet" preparations, or examples of the soft parts of biological specimens, involving not only the most careful and difficult preparation by cutting into sections, dissecting, colouring, and labelling, but presenting the additional problem of preservation from decay. This last is and generally has been achieved by keeping the objects in clear spirits of wine in sealed glass vessels. This plan had so far answered that in the Museum there were many preparations which had been made and put up by John Hunter himself. Hunter died in 1793 , so these were more than eighty years old, and still in good condition. There were also some examples prepared by Reish in the days of Peter the Great, dating from i717. To improve upon methods so 
well understood, which had also stood the test of time, three possibilities presented themselves. New ideas might be evolved. New material might be found, either to keep the preparations from decay or to replace the glass vessels in which they were contained. Lastly, a new and suggestive order of arrangement and classification might be evolved. The last was part of Flower's general scheme and principle. For the first he was ready with a plan for labelling every essential part of the objects in the liquid in which they were suspended. The use of new material was also to some extent practised, and in very ingenious fashion, though it was found that the old-fashioned spirits of wine were in the main the most suitable medium for preservation. The next object after securely preserving the specimens was that the glass and the liquid containing them should be absolutely colourless, like water. When improved methods of glass-making rendered it possible, flat-sided glass cases were used, and the tops fastened on and hermetically sealed. Even in this there were occasional difficulties. When indiarubber, which formed part of the sealing solution, became scarce and dear, an inferior preparation was supplied by the trade, the use of which might have endangered specimens designed to last for ever. Consequently the Museum authorities began the practice of purchasing the ingredients for the sealing substance themselves, and making it up in their own laboratory. Labelling the different parts of 
the objects in the spirits was a great need, but one extremely difficult to meet. If any one will consider how, before suspending from a substance like glass, in a fluid like spirits of wine, an elaborate section of a part of the respiratory or circulating system of a large mammal, he would proceed to affix labels to all the different parts, that these labels might remain perfectly legible, fixed, and without corrosion or decay, he will possibly begin to feel the difficulties of the problem. The matter was keenly discussed between Flower and his assistants. The former suggested fastening small and light numbered labels of enamelled metal to the different parts. These numbers could then be made to refer to a book of names corresponding, to be attached to the outside of the glass case. Mr. W. Pearson, to whose province these preparations more particularly fell, suggested that the spirit would probably not affect printed paper, provided that the paper and ink were of the very best, as it preserved such very delicate animal substances. Flower recommended him to try some for a year in spirits and to note the result. In doing so he was careful to select the very best paper and printing, and to that end cut up some portions of the Zoological Record, the chief scientific production of the Royal Zoological Society, which is printed with ink on paper intended to last. The result was quite satisfactory. Since then the parts of the preparations were all labelled and described in ordinary 
print on slips of paper. These improvements in detail may not seem of importance, in comparison with that of the principles which they illustrated. But in the work which Flower had set himself to do, clearness of detail and setting out was of the essence of the matter. The objects shown in "wet" preparations are all suspended in spirit, and not placed on fixed rods fastened to the top or sides, or the movements of the fluid might injure them in time. The means of suspension needed improvement. The rods, or whatever passed through the portions, must be made of some substance which the spirit could not affect in any way. At the same time it was necessary that these rods should be of the lightest possible material. Flower at first used thin rods of glass, often not thicker than a knitting needle. These were passed through the specimen, and suspended from either end by almost invisible threads. Later, a neater invention improved upon this. Instead of glass rods, minute tubes of glass were used as suspending rods. The threads were passed through these tubes from end to end, and the method of suspending the specimens made at once easy and perfectly safe after the ends of the little tubes had been rounded in the blowpipe for a moment to take off the sharp edge which might have cut the threads.

By these means it was easy to suspend two or three specimens in the same case, and so to present the same organ from different points of view, as 
may be seen, for instance, in various cases containing the brains of monkeys.

What may be termed comparative brain shapes and measurements were and are matters of the first importance, both in respect to brain surgery and in questions as to the relations of size and shape of brain to intelligence. It was a subject to which Flower gave particular attention, merging it gradually in his general interest in the study of Anthropology or the Natural History of man. One of the great difficulties in the way of such comparison and inference was that the brains of all the extinct animals had perished for ever, while those of many existing creatures seldom came, after their deaths, into the hands of scientific men. The skulls, on the other hand, were generally available, both of living and extinct animals. As the general form of the brain corresponds pretty closely to the shape of the portion of the skull which holds it, Flower had the happy idea of taking casts of this interior. Such casts were fairly representative of the brain which once occupied the void, and made it possible to render the series in a measure complete.

NoTE. - In reference to the exposition of Darwin's theories in the Museum, it should be said that Flower was on terms of personal friendship with the former, and both he and his wife from time to time spent the end of the week at Darwin's country house in Surrey, to their very great interest and pleasure. 


\section{CHAPTER V}

THE HUNTERIAN MUSEUM-continued.

IN estimating the value of Flower's work, begun in I 862 at the Hunterian Museum, it should be remembered that comparative anatomy was in a great measure in its earlier days the basis of the theory of evolution. That new and leading idea was attracting the greater part of the speculative interest of the time when Flower began to illustrate in concrete form and logical series the facts on which it rests. To show how quickly he was in the field, it will be remembered that it was not much more than three years before his appointment that Charles Darwin wrote in his introduction to the Origin of Species :-

My work is now (1859) nearly finished; but as it will take me many more years to complete it, and as my health is far from strong, I have been urged to publish this abstract. I have more especially been induced to do this as Mr. Wallace, who is now studying the natural history of the Malay Archipelago, has arrived at almost exactly the same general conclusions as I have on the origin of species. In 1858 he sent me a memoir on this subject, with a request that I would forward it to Sir Charles Lyell, who sent it to the Linnæan Society, and it is published in the third volume of the journal of that Society. Sir C. Lyell and Dr. Hooker, who both knew of my work, the latter having 
read my sketch before, honoured me by thinking it advisable to publish, with Mr. Wallace's excellent memoir, some brief extracts from my manuscript.

While the facts and details of the modifications of animal structure were only known to a few, most of whom, like Charles Darwin, Owen, Huxley, and Flower himself, had been intended for the surgical profession, the ordinary student and the outside world could form no judgment, and were largely without material for learning. It was this want which the system so early begun by Flower in a great measure supplied.

As an example of the need of illustrating the principles of the then new theory of evolution by facts and objects, may be cited Flower's intervention in the celebrated meeting of the British Association at Cambridge in September 1862. Before his appointment to the Hunterian Museum he had made a careful study of the brains of the Quadrumana, which was communicated to the Royal Society, and reprinted in a fuller form in November r86r. These investigations were studied by Huxley. At the British Association meeting of I 862 Owen read a paper, in which he maintained, from specimens of the human brain in spirit, and from a cast of the interior of a gorilla's skull, that in man the posterior lobes of the brain overlapped the cerebellum, whereas in the gorilla they did not. He stated also that these characteristics were constant, as was also the presence of a portion called 
the hippocampus minor in the brain of man which was not found in the brain of the apes. Huxley, relying largely on Flower's investigation of the latter, took a different line, and was able to refer his hearers to his authorities. But it was clearly a case in which "seeing is believing." It was at this juncture that "a Mr. Flower, one of the audience," to quote the Times, "rose up and said, 'I happen to have in my pocket a monkey's brain,' and produced the object in question."

For twenty-two years his exposition and comparison of the modifications of limbs, bones, organs of sensation, organs of nutrition, and organs of perception went on, the results being set out in the cases of the Museum. It must not be lost sight of that this labour was positive, not merely illustrative. It was the counterpart and completion of the written work of the first evolutionists. It gave a "corpus" of the facts, all arranged in due and logical order, without which written treatises, however cogent and convincing, could not satisfy practical students eager to make fresh discoveries, or to combine and use the new suggestions and new principles for the benefit of humanity or even the exercise of pure reason.

It would probably be conceded to-day that this substantive contribution to the spread of knowledge and conviction as to the processes of evolution places Flower in the front rank of those engaged in the practical advancement of knowledge in his 
day. It explains, apart from attraction of character and sympathy of pursuits, the steady and lasting regard in which he was held by Sir Charles Lyell, Charles Darwin, Professor Huxley, Professor Rolleston, Sir Joseph Hooker, Lord Lister, and Sir James Paget, and accounts for the conviction of such bodies as the Trustees of the Royal College of Surgeons, and later of the Trustees of the British Museum, that there was a "something" in what he did which was absolutely the best, and could not be replaced. The terms in which each of these bodies expressed themselves when Flower relinquished the work in which he had been engaged go beyond anything which even a warm and hearty appreciation of services rendered usually elicits from the necessary reserve and caution of responsible control. The documents will be found in their due place in these pages.

A nother aspect of the work done should not be omitted in any effort to appreciate now what was done then. Flower's contribution was not only positive, but non-controversial. The facts and story he set out convinced without speaking. The library of natural volumes grew and grew. Any one could consult them. But they neither argued nor tried to prove a point. At the same time they offered themselves ungrudgingly for cross-examination and consultation, for genuine inquirers to form their own conclusions from. This was particularly valuable in the earlier days, when attention was some- 
what diverted from the peaceful and progressive study of the phenomena which the theory of evolution illuminated, by the feeling and temporary aberration of sympathy caused in some minds by an imperfect appreciation of what it all meant. If minds agitated by the question, "Is man an ape or an angel," chose to engage themselves in the contemplation of Flower's object lessons in Lincoln's Inn Fields, they were pleasantly and soothingly convinced that a good many years would probably elapse before we had learnt the complete premises necessary for speculating whether we were either the one or the other.

It has been mentioned that Flower did not greatly occupy his time with the articulation or preparation of the immense number of illustrative objects at Lincoln's Inn Fields. He mainly confined himself to initiating and explaining what he wanted done. Sir William always and uniformly gave credit to his early assistants in this department. In an address at South Kensington in July 1876 he said that "Great advances in the art of preparing specimens for the purposes of teaching had been made at the Royal College of Surgeons by his namesake, Mr. Flower, who had worked at the Museum for so many years, and was by far the most skilful skeleton-maker in Europe. Mr. Flower and himself had invented a method of articulating skeletons in such a manner that any single bone, or set of bones, could be removed from 
a skeleton without disturbing the remainder. He showed this by removing first the arm and then the leg of the skeleton of a Pangolin; restoring these members, he then took out the vertebral column entire,-in fact he took to pieces and then refitted the whole skeleton." We are so used to-day to seeing all the parts of natural objects or of whole tribes and orders exquisitely arranged and set out, that we are apt to forget that none of this analytic illustration of modifications of natural structure or of the beauties of natural ornament then existed, and that Flower, without having stated a programme, was trying to convince the public as well as scientific men, by very gentle persuasion and practical example, that a change of teaching was needed and was possible. That was not the time when half a million people yearly would have visited a zoological museum, as happened in the last year of his directorship of the Natural History Museum. In the address mentioned above, he took occasion to say a word or two on the great importance of such a matter as the proper stuffing of skins, and especially of bird's skins, so that they should be lifelike works of art. He urged that taxidermy, or "stuffing," was an art which deserved much more attention than it received. A bird-stuffer then was little better than a mechanic; nor could it very well be otherwise when he was so badly paid, even if he did good work. He was often horrified to see the collections of stuffed birds in local museums. He might 
possibly have added "in the British Museum" also, had he thought it desirable; and he urged that it would be far better to pay a high price for a few well-stuffed specimens than to have cabinets full of monstrosities. It would be better merely to have the birds' skins in drawers. There was very much more in this address which was at that time new to the public; and it is very interesting to see how Flower gradually carried most of his points and made them part of what may now be called general policy in such matters. Except in the cases of British birds and their nests, which originated with Dr. Günther, improved taxidermy remained to the end largely an unfulfilled desire as far as the Natural History Museum was concerned, simply because there was not enough money forthcoming to pay for these works of art. But he was able to make a'beginning by employing: some of the few real artists in the business. When there was a little spare money he caused a few artistically stuffed birds to be set in the wall cases, where the series of families and subfamilies are shown. Contemplating some of these, which looked almost alive among the old specimens from Bloomsbury, he remarked that he hoped that they would convert the public by contrast. They seem to have convinced the Trustees in any case, for the progress lately made, on the lines which Flower marked out, and under the care of Dr. Bowdler Sharpe and Mr. W. Ogilvie Grant, has been rapid. But this belongs to the period not of con- 
version but of realisation. In 1876 , at the time of the address referred to above, even artists seem to have thought that the impossible stuffed birds and beasts in museums were lifelike presentations of reality. Flower took the trouble to go round the Royal Academy Exhibition to look at the animal paintings there. Whether he took the idea from Frank Buckland, or whether Buckland, who attended and was much delighted with the address referred to above, took the idea from him and made it one of the annual features of Land and Water, does not appear. But what Flower saw so surprised him, that he took his audience into his confidence, remarking that though he had seen many beautiful landscapes and other paintings, they contained representations of absolutely impossible birds and beasts, which never could exist or have existed, and that these were apparently copied from the stuffed objects accepted as being representative of nature. The indifference of the time to this very obvious side of truth to nature is rather striking, because Landseer was painting his best at that period, and also Wolf and Herring, as well as Mr. Briton Riviere, whose works Flower much admired. But some other great artists seem to have been blind to facts of the kind until their attention was drawn to the defects. Readers who visited the first and best collection of Millais' works ever brought together may remember his very early pre-Raphaelite pictures. In one of these, in which Ariel is 
whispering in Ferdinand's ear, the transcript of nature is so minute that the holes eaten by caterpillars in the chestnut leaves are carefully painted. Yet in a painting of nearly the same time, "The Pot of Basil," a badly-stuffed falcon, which looks as if it had been straightened out in a box and then put on a stand without adjustment, is perched on the back of one of the young men's chairs. It is so faithfully painted that any one might imagine that a stuffed falcon was part of the dining-room furniture. The advances made subsequently in what is practically a new art owe much to his encouragement and later advocacy of the necessity for true and artistic and lifelike work of this kind. At the time they were uttered his remarks also made a considerable impression. Frank Buckland, in concluding an account of the address, said :-

I should like to make one or two remarks on my own account. The employment of women is one of the questions of the day, and I really do not see why some of the lady students at South Kensington should not study taxidermy as well as painting and drawing. It is an art which requires great delicacy of touch, combined with taste, and there is always a sale for well-mounted objects of natural history, particularly birds. When I was a boy I remember quite well that it was fashionable for ladies to make wax flowers. This seems now to have quite died out, and I should like to see the art of bird-stuffing taken up by some ladies.

The demand for well-set-up specimens is now very much greater than it was then, and as the skins are generally obtained from the collectors before they are stuffed, there is nothing unpleasant in the 
work for ladies to do, and Frank Buckland's suggestion seems quite as valuable at present as it was then.

Enough has been said to show that Flower was essentially a reformer in matters connected with museums. Mr. J. W. Clark, Registrary of the University of Cambridge, says :-

Of all the changes which Flower introduced in the Hunterian Museum none was so startling, and none, it may be added, more admirable, than his abolition of the line of demarcation hitherto drawn between recent and extinct forms. Professor Owen had advocated this course in a report addressed to the Museum Committee, dated 2 Ist December I $84 \mathrm{I}$, and the Committee had accepted his views in a resolution dated Ioth February 1842 , but for various reasons the change had been deferred. In 1883 , however, Flower was able to announce that the old series of "fossils" had been broken up, each specimen placed among its allies, according to its zoological affinities, and recorded in its new position in the catalogue then in progress. Prejudice dies hard, and stratigraphical considerations have still so strong an influence, that this is probably the only museum in which so enlightened an arrangement has been adopted. Here, however, he who runs may read the important truth that there has been no break in the continuity of life upon the earth. 


\section{CHAPTER VI}

\section{FAMILY LIFE IN LINCOLN'S INN FIELDS}

Though Flower began his work at the Hunterian Museum on January I, I 862, it was not till April I 5, the fourth anniversary of their wedding-day, that he, Mrs. Flower, and the two children began to reside there, a day of good augury for the twenty-two "perfectly happy years" which they were destined to spend there before his appointment to the British Museum of Natural History brought them to live in Stanhope Gardens, to be near the scene of the day's work. There five more children were born to them, making in all a healthy and happy family of seven, who grew up together, and were able to be the companions not only of their mother, but of their father, to a degree which does not always occur when the head of the family is deeply engaged in successful work.

After the lapse of a few years the echoing chambers and gallery of the Museum were often converted into a playroom for a family of delighted children "after office hours." What used to happen is perhaps best quoted from a letter from Flower's 
eldest daughter, now Mrs. Shann of Micklegate, York :-

When we were all small, and very happy and energetic, the Museum of the College of Surgeons was a most familiar place to us, as we lived in the house next door, and my father used to enter it at all hours, and often take us with him. We delighted in these visits, and had our special favourites among the exhibits. These selections were of course personal, and not scientific. The most exciting were the tall skeleton of the Irish giant, and that of the little Polish dwarf with her tiny shoe and thimble, which had long been among the treasures of the collection. Another great object of our admiration was the remains of the Siberian Mammoth, with its real skin-and hair, and the monkeys. These on certain wet half-holidays we were allowed to have out to play with instead of a doll, whilst we paid and received visits from and in our respectives "houses" under the big whale or the giant sloth, which still are conspicuous and formidable figures in the collection. I always recall the odour of fresh paint and varnish (on the cases and stands) and the peculiar smell of the carefully prepared and whitened bones. Occasionally we were allowed the excitement of a good run round in the upper galleries "all among the bottles." One of the strongest desires of my childhood was to be allowed to spend a night in the Museum! This naturally was not gratified. But later I spent many evenings there aiding my father in the rather laborious work of measuring the great number of skulls in the Barnard Davis Anthropological Collection. It was rather weird work, going into the great empty halls, our footsteps and voices echoing through the silence, and then sitting with the light of a lamp falling on rows of skulls which one by one were filled with seed as the elaborate measurements were taken.

Flower's temperament and constitution were so equable and so happily related to his mental characteristics that he was able to enjoy family life and society to the full while engaged in active 
and steady application to his congenial but engrossing work. His house, which, like many others in Lincoln's Inn Fields, was large and old-fashioned, after the good and spacious style of 200 years ago, was next door to the fine building of the Royal College of Surgeons, of which the Museum is a part. It had an old-fashioned and handsome staircase, carved doors and shutters, and a view looking right over the beautiful gardens of the "Fields," the largest square in London, and containing the finest and oldest plane trees in the Metropolis. An opening to the west showed all the beauty of London sunsets. The lawns and timber of the gardens made a charming playground for the children, while their beauty was a constant source of rest and refreshment merely to look upon.

\section{Lady Flower says :-}

"It was like living on an island; the crowded noisy streets of Holborn and the Strand lay at no great distance north and south of us, yet the green oasis of the gardens, and the perfect quiet, especially in the mornings and evenings, were never interfered with. After the closing of the offices of the solicitors and other men of business who frequented Lincoln's Inn Fields during working hours, there were no sounds except the curfew bell of Lincoln's Inn Chapel, which, though in the centre of the great city, reminded one of Oxford or Cambridge. We had a most interesting link with the past of the 'Fields' in Mr. Balfour, then eighty years of age, the veteran Secretary of the Royal College of Surgeons. He remembered the days when Lincoln's Inn Fields were still one of the residential parts of London. Seven peers had houses there, and lived in the old-fashioned state of the previous generation. One of his great admirations as a boy was the sight of the ' coaches' with four horses standing outside the gates. Later, the 
occupiers moved gradually westward, and the fine old stone-pointed houses with their panelled walls and elaborate ceilings became the home of the principal physicians and surgeons of the day. Several of the judges also had houses there. Later still in Mr. Balfour's lifetime, these too moved westwards, and the houses were turned into legal offices and lawyers' chambers. Then when we came to live there, Mr. Balfour having passed his 'four score' years, ours was the only house in which a family was resident, and ours almost the only children beside those of some of the city clergy who played under the big plane trees in the gardens."

Later in life, when asked by the publisher of Who's Who to describe his recreations, Flower gave as answer, "Walking and reading aloud." $\mathrm{He}$ delighted to walk both in London, in the country, and abroad, with his children as companions. So long as they remained in the family circle, and whether as children or when grown up, they found this one of their greatest enjoyments, as did their father.

At Lincoln's Inn Fields (Mrs. Shann writes), even through the busiest times of his London life, it was our father's custom to take a walk every fine day between leaving the Museum and dinner, and it was our special delight to accompany him. Sometimes it was a stroll along the Embankment or round the gardens of different squares. More often there was some definite place to go to, perhaps to the fascinating animal shops in the Seven Dials, or to Covent Garden market. Then we would perhaps turn up some side street or court and enter an old building, once a fine house in the days of Charles II. or Queen Anne, with wide staircases and carved doorways, now half dilapidated, dark, and dusty. But when we had penetrated into some inner room, we would find some printer or lithographer at work, as often as not upon the illustrations of a scientific 
treatise or contribution to natural history, which he was either publishing himself, or which some friend was bringing out, and which he was supervising or helping in. Among our regular and much-appreciated expeditions were our visits with him to the Zoological Gardens. We generally went on a Sunday afternoon, often walking both there and back, and sometimes going on to tea with some of his friends near, especially the Henry Pollocks, or to the Huxleys, where there was generally a pleasant gathering of friends concerned either in science or art. What interested my father more particularly at the Gardens were some of the inmates of the small mammal house, and the ant-eaters and sealions. We were never tired of watching the latter, with their clever old French keeper Lecompte. Each of us had of course our special animals which we always wanted to see; and we never thought a visit complete unless we were taken "behind the scenes" of the bison and cattle sheds, where we could peep into their stalls from the back. Nor did we ever consider that we had done our duty there socially to our animal friends until we had been lifted up over the elephant railings to feed them with the "crunchy" biscuits which the keepers can always provide in any number from their pockets. What my father liked best, and would have done much to further were it possible, was to see every animal as far as possible in its natural state. He would always stand watching an elephant taking a bath, or the little beavers on the rare occasions on which they came out of their house by day and swam about.

The monkey and parrot houses were not so often visited. But the old reptile house, near the kangaroo sheds, was always a favourite resort. My sister and I used to delight in having some of the harmless snakes out, and in being allowed to handle them and let them twine round our necks, often startling the other visitors who happened to be near. My father was greatly amused one day. While we enjoyed ourselves in this manner, an officious but well-intentioned old gentleman remonstrated with him on the danger we were running. It was explained to him that these were harmless, non-poisonous snakes. "Excuse me, sir," was the reply, "but you can never trust those serpents. You never know when they might turn venomous!" 
In later days, when he had been elected President, he always did his best to encourage the better housing of the animals. The building of the new lion house and the new reptile house were both a source of great satisfaction to him. The nocturnal animals, as every visitor regrets to find, are, as a rule, almost invisible or very torpid by day. For the benefit of some special friends who were really interested in the subject he formed a party to visit the Gardens at night in order to see the nocturnal creatures in their waking hours. $\mathrm{He}$ always thoroughly enjoyed taking people to the Gardens who showed a real interest in or appreciation of what they saw. I think amongst the very last whom he so conducted was the King of Siam, the titular "Lord of Elephants" in his own country.

Occasionally things from the Gardens found their way to our house. Once it was an ostrich egg, fresh laid, which was to be cooked. It took half an hour to boil, and then the shell was found to be so hard that it had to be cracked open with a hammer. Finally it was decided that it should be placed on a salad and sent up in that form. It was considered by us a great success. A baby tiger which died was also sent to Lincoln's Inn Fields. It was stuffed and kept as our ne plus ultra nursery schoolroom toy. Unfortunately a puppy destroyed it one day when we were out.

I mentioned our visits to the Museum in the evening when we were children.

I often think of the contrast between our mode of enjoying ourselves there and the different form of pleasure found by the guests whom our father and mother used to ask there to the many parties which they gave in the Museum, when the whole place was brilliantly lighted up and full of "grown-ups" in evening costume enjoying the novelty of meeting in such unusual surroundings. We used to see a good deal of many of the visitors to our house. I remember the poets Longfellow, Lowell, and Browning; Dean Stanley, who was one of the closest friends of the family; Charles Darwin, and such distinguished foreigners as Virchow, Schliemann, Agassiz, and the black King George of Bonney.

One day, coming in from our play in the gardens, we found a 
tall grave visitor there, who not only accepted one of the daisy chains we had just made, but, to my sister's satisfaction, walked out with it round his neck. That was Charles Kingsley.

Flower's holidays were always shared with his family. Sometimes his friends used to ask, rather dubiously, "Oh, but what did you do?" He always found that his amusements and those of the boys and girls happened to be very much the same. His second daughter, Vera, now the wife of Colonel Biddulph, of Rathrobin, King's Co., writes characteristically of their younger days with her father :-

I have just been reading the life of a distinguished bishop, and am struck by the fact that in it his wife and family are never mentioned unless it is in case of illness and in letters of condolence, which gives an unpleasant impression that they were always ailing! Now in Sir James Paget's life there are constant allusions to their happy family circle, which I think gives a much truer impression - certainly in his case-of what his daily life was. We constantly went away with our father and mother for short visits to the country, and generally for a holiday with them at Easter. But it was the six weeks in August and September that we most enjoyed, and most keenly looked forward to. It was generally on Trinity Sunday that our father, with our mother by his side, used to unfold some delightful plan for the summer holiday. Sometimes it was a tour abroad. Sometimes it was to take a country house in an interesting part of England or Wales. One summer we spent in the old "Cliff House" at Felixstowe, before railways made it crowded. Close by were the red crag cliffs, full of fossils of a comparatively recent date, in which all kinds of remains of fishes, shells, cetacea, and other creatures were in perfect preservation, and easily detached and collected. With him we made a fine collection of sharks' and other teeth, and crag animals generally. Another year a house was taken near Dartmoor. There we had the whole 
moor next the park to roam over, with its tors and bogs to examine, and stones and plants to hear about. On the other side was Plymouth. There the naval connection of our mother's family came in to make things more delightful. They could take us over their own ships, or round the dockyard and up the Sound.

One summer we rented a house at Hornchurch, Essex, owned by Mr. Fry, the youngest surviving son of Mrs. Elizabeth Fry. Most of the owners of the houses which we rented became lifelong friends later. My father had the gift, not common to every one, of quickly getting into a "holiday humour"; he was soon in the best of spirits, composing nonsense rhymes about our adventures on our journey, and illustrating these by pictures of the kind we appreciated. Three summers we spent in Holland, one in the region of extinct volcanoes on the Rhine. Several were spent in Switzerland, one divided between Normandy and Brittany, another in the Engadine. When we had grown old enough we explored with him the whole neighbourhood on foot, sometimes prolonging these excursions for three or four days. During these walks he told us and showed us all the interesting points which occurred to him as to the natural history and geology of the delightful places we walked through. $\mathrm{He}$ was very well up in the political history too, which we picked up from him in this pleasant and easy way. It is infinitely easier to remember what you have heard among things which you see, than to retain what has only been read in a book. It has always been a matter of surprise to me how he managed to have most of the internal history of some small German or Italian state at his finger ends, as if political, not natural history, were the subject of his profession.

When the journeys were too far for the children, they were welcome guests with both the grandparents in Warwickshire and Buckinghamshire, whilst Flower and his wife travelled together in Germany and Italy, delighting in all the interests of Venice, Florence, and Rome. But 
their most important journey was in 1873 , when hard work had begun to tell so seriously on Flower's health that his friends were alarmed, and strongly urged a period of rest in a warm climate. The Council of the College of Surgeons met, and unanimously voted him six months' leave of absence. Sir James Paget and Professor Huxley warmly advocated Egypt as far superior in climate, as also in interest, to the Riviera or Algiers. The chief anxiety was then about the children, soon solved by Flower's father and mother undertaking the care of the elder ones, whilst his brother, Charles Edward Flower, and his wife kindly invited the younger ones to their charming house by the river Avon.

"Thus Flower and his wife," says one who has kindly contributed a reminiscence of this time, "started in November 1873 across Italy, and taking the P. \& O. steamer at Venice for Alexandria, remained five months in Egypt, going up the Nile in the sailing dahabeeah of kind friends as far as the First Cataract, and returning home by the long sea-route in May 1874. He wrote some valuable notes on the climate at the time, and enjoyed drawing birds and animals in the water-colour landscapes taken by his wife, it giving him positive delight to see the cranes, flamingoes, pelicans, spoonbills, hoopoos, and other birds enjoying wild life, which he had hitherto only known in Zoological Gardens and Museums. 
"Altogether they found the climate most beneficial for health, and that the art and history of ancient Egypt, as well as its present beauty, with the glory of its sky, enriched their whole future lives."

-After their return from Egypt an innovation was made at the Museum by inviting ladies as well as gentlemen to evening parties held there by Professor and Mrs. Flower. 


\section{CHAPTER VII}

\section{CHARACTER AND FRIENDSHIPS}

A strong friendship with Dean Stanley played an important part in the lives of both Sir William and his wife.

The friendship began spontaneously, yet there was, as is often the case, a kind of common link, which possibly aided the first acquaintance incidentally. Captain Owen Stanley, a brother of Arthur Stanley's, had been commander of H.M.S. Rattlesnake, on board which Huxley sailed on the four years' surveying cruise round the world during which Owen Stanley died. "The fact that Huxley had sailed under Captain Owen Stanley brought him into very friendly communication with the Captain's brother, the late Dean of Westminster," Flower wrote in some reminiscences of Professor Huxley - " the Dean as many of us liked to, and still do call him, just as the first Duke of Wellington was always called the Duke." Notwithstanding the great differences of their interests and pursuits, they remained in the closest intimacy, Stanley's marriage only increasing the friendship. In 1863 he married 
Lady Augusta Bruce, fifth daughter of the Earl of Elgin (who had enriched the British Museum with the Greek sculpture popularly known as the "Elgin Marbles"). Lady Flower writes: "She had a charming personality and was highly accomplished; brought up in Court, she had the most perfect manners, but in her case they were only the outward sign of the warm heart and high character within. The chosen friend of Queen Victoria and beloved by the Royal Family, Lady Augusta yet devoted herself to the poorest of the poor in Westminster, and entered heart and soul into her husband's arduous life, showing a fine courage in supporting him when his great liberality of thought brought fierce attacks on him from those who could not understand that the width of his views was due, not to indifference to church tenets, but to depth of feeling and the endeavour to lead men's thoughts back to the simpler Christianity of the Apostolic age."

Flower's first acquaintance with Huxley was not through the Stanleys, but arose from his early friendship with Professor George Busk, who, after being Surgeon to the Seamen's Hospital on the Dreadnought, settled in Harley Street. Busk had been the first person to encourage Huxley when he returned from his Rattlesnake cruise. $\mathrm{He}$ was. a man of distinction in his profession, and became President of the Royal College of Surgeons, but his principal pleasure was in purely scientific pursuits, and he, jointly with Huxley, translated 
and edited Kölliker's Manual of Human Histology. While Huxley knew and was fast becoming a warm friend of Flower's, and also knew the Dean, the first notice of the latter in connection with Flower is an entry in Lady - then Mrs.-Flower's diary, that they "attended the service in Whitehall Chapel, and heard Dr. Stanley preach." "Arthur Penrhyn Stanley, when Dean of Westminster, became later our greatest friend," Lady Flower writes.

My husband was impressed by Stanley's views and sympathies, as well as by his large-minded charity and insight, always dwelling on the spirit rather than on the letter of religion. He said that Stanley was the most truly "liberal" man whom he knew. He showed notable courage at the time of the first publication of Darwin's Origin of Species. He preached in the Abbey, and took for his text, "Let there be light," maintaining that the truth must be right, even if our limited minds could not yet understand it all. We never willingly missed an opportunity of hearing Dean Stanley, whether in the Abbey or in the numerous churches where he was asked to preach. The Deanery of Westminster, graced by the best hostess of the day, Lady Augusta Stanley, became one of the most interesting and delightful houses in London. All classes from Royalty downwards, and all nationalities, I may even say all creeds, met in the Deanery as on neutral ground. Lady Augusta had the art of making every one feel happy, and inducing them to show themselves at their best.

The Dean and his wife had no children of their own, but both had a real love for children-the Dean once remarked that children were like the undergrowth in a wood, connecting the large trees which would otherwise stand apart in isolation, -and soon 
became warmly attached to the bright and pretty children at Lincoln's Inn Fields, to whom they extended a degree of affection and confidence which was thoroughly understood and returned. The Dean first instituted Children's Services on Innocents' Day in Westminster Abbey, to which the Flowers' children duly went. But he not only gave them a service. $\mathrm{He}$ also provided tea for those of his small relations and friends who came to hear him, and after "Abbey," as a Westminster boy would say, the cheerful little boys and girls used to pass from the dim Abbey, at the close of the short winter's day, into the bright warm Deanery and enjoy the one meal which children really regard as a social function devoid of responsibility, with all their particular friends. The Dean and his wife were godparents to two of the Flowers' children, and the youngest, who was born after Lady Augusta's lamented death, was christened by the Dean, and named after her.

Speaking of Dean Stanley (says Flower in his personal memoir of Huxley contributed to the Proceedings of the Royal Society), I am reminded of a meeting which took place at my house in Lincoln's Inn Fields on November 26,1878 , just after his return from a visit to the United States. He had a great wish to see Darwin, who was one of the few remarkable men of the age with whom he was not personally acquainted. They moved in totally different circles, Darwin, owing to ill-health, having totally given up going into general society. So we arranged that they should both come to lunch. They were mutually pleased with one another, although they had not many subjects in common to talk about. Darwin said that he had a great respect for Stanley, regarding him as 
a thoroughly honest man. Darwin was no theologian, and Stanley did not take the slightest interest in, nor had he any knowledge of, natural history, although his father was eminent as an ornithologist, and President of the Linnæan Society. I once took him over the Zoological Gardens. His remarks were original and amusing, but the sole interest he appeared to find in any of the animals was to discover some human trait either in appearance or character. ${ }^{1}$ The Dean enjoyed intensely the broader beauties of nature as shown in scenery. But the details of animal and plant life were entirely outside his sympathies. . . . If I had the faculty of a Boswell I should have much worth narrating of the many little dinner-parties at one or the other of our houses, at which Huxley and the Dean were the principal talkers. A characteristic rencontre between them took place also on one of the ballot nights at the Athenæum. A well-known popular preacher of the Presbyterian Church, who had made himself famous by predictions of the speedy coming of the end of the world, was up for election. I was standing by Huxley, when the Dean, coming straight from the ballot-boxes, turned towards us. "Well," said Huxley, "have you been voting for C. ?" "Yes, indeed, I have," replied the Dean. "Oh, I thought the priests were always opposed to the prophets," said Huxley. "Ah," replied the Dean, with that well-known twinkle in his eye and the sweetest of smiles, "but you see I do not believe in his prophecies, and some people say I am not much of a priest."

The kind Dean (writes Lady Flower) used to come to see our children act small plays or scenes from Shakespeare, mounting right up to the nursery, where the acting took place. Scenes from Shakespeare were generally the entertainment, but Dick

1 This failure to transmit the taste is rather remarkable. Stanley on Birds, written by his father, the Bishop of Norwich, was the first book on the subject which the present biographer ever possessed, and was a lasting joy. Rather later the Bishop's gun, a well-made old single-barrelled muzzle-loader, was presented to us by an old Norfolk squire, into whose family it had come. It seems probable that he was a sportsman as well as a naturalist. 
Whittington and his Cat was a standing piece. It was a charming picture to see Stanley, after some official engagement, with his white hair contrasting with the red riband of the Bath (the Dean of Westminster being Chaplain to the Order), the youngest child raised on his knee, whilst he looked on with extraordinary zest at the acting. Indeed, he took such interest as even himself to compose some lines for the children to add to the little play. But this delightful friendship drew to its close in $188 \mathrm{I}$. On the 27 th June of that year he baptized our youngest child, giving her the name of his dear wife, "Augusta," and of her sister, Lady Frances Baillie, and cousin, Mrs. Drummond of Megginch, also Frances. He came to lunch afterwards, cheerful and keenly interested as usual, to the delight of Professor Asa Gray, the accomplished American botanist, then visiting in Europe. It was about the time of the publication of Froude's full and somewhat rough Life of Carlyle, when many readers were painfully distressed by the revelations of temper and apparent discomfort of his domestic life, but the Dean was very comforting in stating that these "revelations" were overdrawn, and said that "words which in print appeared cruel and even savage were in reality so softened by the manner of saying them, or the smile that accompanied them, that Carlyle's admirers need not be troubled about his reputation."

This was the last general conversation enjoyed with the Dean, for he was taken ill a few days afterwards. He was attacked by erysipelas in the head, and on the 18th of July Arthur Penrhyn Stanley passed to his rest in the Westminster Deanery. Sunday the 17 th will never be forgotten by those who attended the evening service in the nave of Westminster Abbey, when the bulletins pasted on the walls of the cloisters announced that the erstwhile principal figure of those services was lying in the adjacent Deanery stricken with mortal illness. 
CHAP.

As the service went on the lines of Charles Wesley's hymn were sung-

Part of the host have crossed the flood, And part are crossing now-

Flower could bear the tension no longer, and whispering to his wife to remain through the rest of the service, he went into the Deanery, where he was welcomed by the devoted sister-in-law, Lady Frances Baillie, and Dr. Gerald Harper, the Dean's doctor and friend, and still more by the patient himself, so that he remained, and relieving some of the watchers, sat up all night with him.

Stanley's mind was clear, though his speech was rendered difficult owing to the swelling caused by erysipelas. Flower's medical training made him a helpful friend in this emergency, whilst, as he was not in practice, there were no difficulties of medical etiquette in his presence in the sick chamber, even had he not been a personal friend of the attending doctors, Sir William Jenner, Sir William Gull, Mr. Prescott Hewitt, and Dr. Gerald Harper. Eventually the latter, with Canon Farrar, informed the Dean that he could not recover. Flower remained with Stanley when Canon Farrar administered the Holy Communion to the Dean, together with the relatives in the house, and some of the household, the Dean himself pronouncing the final blessing, and afterwards shaking hands with all those who had partaken with him. Later Flower read Stanley's own hymn on the Trans- 
figuration aloud to him, and Newman's "Lead, Kindly Light." The Archbishop of Canterbury, Dr. Vaughan, and Canon Farrar were present, together with Flower, when the Dean passed away. "My husband," says Lady Flower, "was so greatly impressed by the last scenes of Stanley's life that he always said that it was 'one of the chief privileges' of his own life to have been permitted to pass these hours with him."

The earnestness which marked the whole of Flower's life and actions was not merely the outcome of a firm sense of duty, any more than his strong family affection was a mere impulse. $\mathrm{He}$ was by conviction and disposition religious. His early environment, though full of positive goodness, was very far from being such as was likely to assist in the development of a mind which found its religious expression in the writings of F. D. Maurice, Charles Kingsley, the Rev. Llewelyn Davies, Dean Church, and Dean Stanley, and the most congenial companionship and comprehension in the region of spiritual matters in their society. The early history of his own family was strictly Puritan, and in strong natural opposition to the prescriptive teachings of the Church. It would be difficult to find a more interesting example of the survival of political Puritanism than in the person of his grandfather, Mr. Richard Flower, of Marden Hill, near Hertford.

He was a man far in advance of his time, full of 
the political dissatisfaction, so rarely found in the county gentleman class, which inspired William Cobbett and other political thinkers of the day. Deeply dissatisfied with the position of affairs in England, he sold his large estate and migrated to America like one of the Pilgrim Fathers, though two centuries later, taking with him his family, "menservants and maidservants, oxen and asses, sheep and goats," not forgetting six couples of fox-hounds and two Scotch deer-hounds; and purchased a huge estate in Illinois. Three ships were chartered to carry the party, and among the first people whom the Flowers met in New York, coming up Broadway in his shirt-sleeves, was William Cobbett.

When Edward Fordham Flower, the youngest son of the former Hertfordshire squire and then ranch-owner, returned to England he was of no definite religious persuasion, nor was there anything in the subsequent family developments to influence William Flower to adopt the attitude towards the Church which he did. His marriage doubtless influenced him very greatly, and probably also the examples in his wife's family showing that religious convictions and loyalty to the Church could be and were accompanied by vigour of intellect and thorough independence of thought and character. Apart from personal happiness, this trend of sentiment and feeling on Flower's part was of great service in allaying and removing differences aroused by the combative character of some 
of the then leaders of science and best equipped exponents of evolution.

On viewing the recent expression of opinion as to first causes by Lord Kelvin, whose acquaintance with the physical force of nature is almost unrivalled, it is interesting to note the steps taken by Flower to show the world that those whose knowledge of biology and evolution was second to none were by no means of opinion that what had been discovered was tantamount to a "dispensing power" giving them leave to cut the ropes tying them to older and established convictions and beliefs.

In October 1883 Flower was asked to give an address at the Church Congress at Reading. The Bishop of Oxford presided, and after his address the greater part of the day was given up to the question of the bearings of science on religion as happily expounded by Flower. It was an idea, due to the authorities of Balliol College, ${ }^{1}$ Oxford, to bring him to give an account, at once authoritative and simple, of the meaning of evolution, and of the kind of evidence on which it rests. It may well be doubted whether, if he had to deal with the same subject to-day, he would alter his statements or his conclusions.

1 Sir John Conroy, Bart., Fellow and Tutor of Balliol, was greatly impressed by the mischief done to many young men brought up in narrow homes, who were taught that "evolution" was "against religion." When they came up to the University and were taught the theory of evolution, they were inclined to give up their former beliefs as well, supposing that they must stand or fall together. 


\section{In his address he said :-}

The doctrine of continuity, or of the direct relation of an event to some preceding event, according to a natural and orderly sequence, is now generally recognised in the organic world; and it is a curious circumstance that though the modern expansion of this doctrine, as applied to the living inhabitants of the world, appears to many so startling, and has met with so much opposition, it is in a more restricted application a very old and widespread article of scientific as well as of popular faith. The expansion of the special branches of knowledge affecting our views upon this subject has taken place in many different directions, of which I can here only indicate the most striking.

I. The discovery of enormous numbers of forms of life the existence of which was entirely unknown a hundred years ago. The increase of knowledge in this respect is something inconceivable to those who have not followed its progress. Not only has the number of well-defined known species multiplied prodigiously, but infinite series of gradations between what was formerly supposed to be distinct species are being constantly brought to light.

2. Vast increase in the knowledge of the intimate structure of organic bodies both as revealed by ordinary dissection and by microscopic examination, a method of investigation only brought to perfection in very recent years.

3. 'The comparatively new study of the geographical distribution of living things, which has only become possible since the prosecution of the systematic explorations of the earth's surface which have distinguished the present century. The results of this branch of inquiry alone have been sufficient to convince many naturalists of the unsoundness of the old view of the distinct origin of species, whether created each in the region of the globe to which it is now confined, or, as many still imagine, all in one spot, from which they have spread themselves, unchanged in form, colour, or other essential attributes, to their present abodes, however diverse in climate and other environments or conditions of existence.

4. Lastly, though most important of all, must be mentioned 


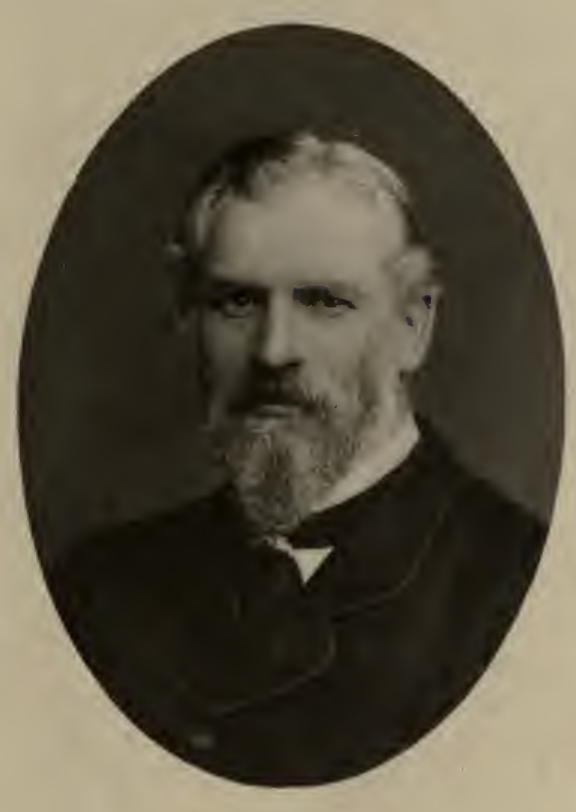

Priffarem Thum FR

1883. 

the entirely new science of palæontology, opening up worlds of organic life before unknown, also showing infinite gradations of structure, but mainly important as increasing our horizon of observation to an extent not previously dreamt of in the direction of time. Porvers of observation formerly limited to the brief space of a few generations are now extended over ages which the concurrent testimony of various branches of knowledge-of astronomy, cosmogony, and geology - show are immeasurable compared with any periods of which we hitherto had cognisance. The result may be stated to be that the opinion now almost if not quite universal among skilled and thoughtful naturalists of all countries, whatever their beliefs on other subjects, is that the various forms of life which we see around us, and the existence of which we know from their fossil remains, besides the innumerable others of which the remains do not exist or have not yet been discovered, are the product not of independent creations, but of descent with gradual modifications from pre-existing forms. In short, the law of the natural descent of individuals, of varieties, races, or breeds (which being within the limits of the previous powers of observation are already universally admitted), has been extended to the still greater modifications constituting what we call species, and consequently to the higher groups called genera, families, and orders. The barrier fancied to exist beween socalled varieties and so-called species has broken down. In fact the onus probandi now seems entirely to lie with those who make the assertion that species have been separately created. Where, in fact, it may be asked, is the shadow of a scientific proof that the first individual of any species has come into being without pre-existing parents? Has any competent observer at any time witnessed such an occurrence? The apparent advent of a new species in geological history, a common event enough, has certainly been cited as such. As well might the presence of a horse in a field with no other animals near it be quoted as evidence of the fallacy of the common view of the descent of individuals. Ordinary observation tells us of the numerous causes which may have isolated that horse from its parents and kindred. Geologists know equally well how slight are the chances of more than a stray individual or fragment of an individual here and there being 
first preserved and afterwards discovered to give any indication of the existence of the race. When we contrast the present knowledge of palæontology with what it was fifty or even ten years ago, when we see by what accident, as it were-a railway driven through a new country, a quarry worked for commercial purposes, a city newly fortified-all the most important discoveries of extinct animals have been made, we must be convinced that all arguments drawn from the absence of the required links are utterly valueless. The study of palæontology is as yet in its merest infancy; the wonder is that it has already furnished so much, not so little, corroboration of the doctrine of transmutation of species. Direct proof is then equally absent from both theories. For the old view it may be said that it has been held for a very long time by persons whose knowledge of the facts of Nature which bear upon it was extremely limited. On the other hand, the new view is continually receiving more support as that knowledge increases, and furnishes a key to the vast numbers of otherwise inexplicable facts in every branch of natural history, in geological and geographical distribution, in the habits of animals, in their development and growth, and especially in their structure. The question of the fixity or the transmutation of species is a purely scientific one, only to be discussed and decided on scientific grounds. To the naturalist it is clearly one of extreme importance, as it gives him for the first time a key to the interpretation of the phenomena with which he has to deal. It may seem to many that a question like this is entirely beside the business of a Church Congress, as it is one with which only those expert in the ways of scientific investigation and deeply imbued with a knowledge of scientific facts could be called upon to deal. This would certainly have been my view if it had not been that some who, from their capacities and education, should have been onlookers in such a controversy, awaiting the issue of the conflict while the lists are being fought out by the trained knights, have rushed into the fray, and by their unskilful interposition have only confused the issues, casting about dust instead of light. In the hope of clearing away some of this dust the present discussion has been decided upon. It is self-evident that a solid advance of any branch of knowledge must in some way 
or other, and to a greater or less degree, influence many others, even those not directly connected with it, and therefore the rapid simultaneous strides of so many branches of knowledge as may be embraced under the term of "recent advances in natural science" will be very likely to have some bearing upon theological beliefs. Whether in the direction of expanding, . improving, purifying, elevating, or in the direction of contracting, hardening, and destroying, depends not upon those engaged in contributing to the advance of science, but upon those whose special duty it is to show the bearing of those advances upon hitherto received theological dogmas. The scientific questions themselves may well be left to experts. If the new doctrines are not true, there are plenty of keen critics among men of science ready to sift the sound from the unsound. Error in scientific subjects has its day, but it is certain not long to survive the ordeal, yearly increasing in severity, to which it is subjected by those devoted to its cultivation. On the other hand the advances of truth, though they may be retarded, will never be stopped by the opposition of those who are incompetent by the nature of their education to deal with the evidence on which it rests.

There is no position so fraught with danger to religion as that which binds it up essentially with this or that scientific doctrine, with which it must either stand or fall. The history of the reception of the greatest discoveries in astronomy and geology, the passionate clinging to the exploded pseudo-scientific views on those subjects supposed to be bound up with religious faith, the fierce denunciation of the advocates of the then new, but now universally accepted, ideas, are well worn subjects, and would not be alluded to but for the repetition-almost literal repetition in some cases-of that reception which has been accorded to the new views of biology. Ought not the history of those discoveries, and the controversies to which they gave rise, to be both a warning and an encouragement? Those who hoped and those who feared that faith would be destroyed by them have been equally mistaken; and is it not probable that the same result will follow the great biological discoveries and controversies of the present day? In stating thus briefly what is the issue of these discoveries, as generally understood and accepted by men 
of science, I have done all that I promised, and must leave, in far more competent hands, the part of the subject especially appropriate for discussion at this meeting. I may, however, perhaps be allowed to put a few plain and simple considerations before you which may have some bearing upon the subject. I - said at the commencement of this paper that it has long been admitted by all educated persons, whatever their religious faith may be, that that very universal, but still most wonderful process, the commencement and gradual development of a new individual of whatever living form, whether plant, animal, or man, takes place according to definite and regularly acting laws, without miraculous interposition. Further than this, I believe that every one will admit that the production of the various races or breeds of domestic animals is brought about by a similar means. We do not think it necessary to call in any special intervention of creative power to produce a short-horned race of cattle, or to account for the difference between a bulldog and a greyhound, a Dorking and a Cochin China fowl. The gradual modifications by which these races were produced, having taken place under our own eyes as it were, we are satisfied that they are the consequence of what we call natural laws, modified and directed in these particular cases by man's agency. We have even gone further, having long admitted, without the slightest fear of producing a collision with religious faith, that variation has taken place among animals in a wild state, producing local races of more or less stable and permanent character, and brought about by the influence of food, climate, and other surrounding circumstances. The evidences of the Divine government of the world, and of the Christian faith, have been sufficient for us notwithstanding our knowledge that the individual was created according to law, and that the race or variety was also created according to law. In what way, then, can they be affected by the knowledge that the somewhat greater modifications, which we call species, were also created according to law? The difficulties, which to some minds seem insuperable, remain exactly as they were; the proofs, which to others are so convincing, are entirely unaffected by this widening of scientific knowledge. Even to what is to many the supreme difficulty of all, the origin of man, the same 
considerations are applicable. Believe everything you will about man in his highest intellectual and moral development, about the nature, origin, existence, and destiny of the human soul; you have long been able to reconcile all this with the knowledge of his individual material origin according to law, in no whit different in principle from that of the beasts of the field, passing through all the phases they go through, and existing long before possessing, except potentially, any of the special attributes of humanity. At what exact period, and by. what means, the great transformation takes place, no one can tell. If the most godlike of men have passed through the stages which physiologists recognise in human development without prejudice to the noblest, highest, most divine part of their nature, why should not the race of mankind, as a whole, have had a similar origin, followed by similar progress and development, equally without prejudice to its present condition and future destiny? Can it be of real consequence at the present time, either to our faith or our practice, whether the first man had such an extremely lowly beginning as the dust of the earth, in the literal sense of the words, or whether he was formed through the intervention of various progressive stages of animal life? The reign of order and law in the government of the world has been so far admitted that all these questions have really become questions of a little more or a little less order and law. Science may well be left to work out the details as it may; it has thrown some light, little enough at present, but ever increasing, and for which we should all be thankful, upon the processes or methods by which the world in which we dwell has been brought into its present condition. The wonder and mystery of creation remains as wonderful and mysterious as before. Of the origin of the whole, science tells us nothing. It is still as impossible as ever to conceive that such a world, governed by laws, the operation of which have led to such mighty results, and are attended by such future promise, could have originated without the intervention of some power external to itself. If the succession of small miracles, formerly supposed to regulate the operations of nature, no longer satisfies us, have we not substituted for them one of immeasurable greatness and grandeur? 


\section{CHAPTER VIII}

LATER WORK AT LINCOLN'S INN FIELDS

IN 1863 Professor Owen resigned the Hunterian Professorship at the Royal College of Surgeons, which he had held since he had relinquished the Conservatorship of the Museum two years previously. On Friday evening, April 25, Flower wrote to Huxley, with whom he was on terms of steady friendship, which lasted till the Professor's death :-

My DEAR Huxi.Ey - At a meeting of the Court of Examiners this evening, it was unanimously decided that " there's not a man in all Athens that can discharge Pyramus" (i.e. the Hunterian Professorship) but you. Will you therefore take steps to obtain the necessary qualifications? Perhaps you can come here some day soon and talk to the Secretary about what certificates will be required? The President told me that he should endeavour to make the examination itself as comfortable as possible for you under the circumstances, but the formalities must be complied with. You can come up the week after next, any evening that suits you best. I am exceedingly rejoiced myself at the prospect of the new "Hunterian Professor," though I don't know what our illustrious predecessor will say.

Huxley was elected to the post, which brought him and Flower into close professional as well as friendly relations for some years. 
In 1864 Flower was elected a Fellow of the Royal Society, on the Council of which he several times served, and of which he was Vice-President twenty years later. "My dear Darwin," Huxley wrote on January 18, I864, "I have had no news of you for a long time, but I reasonably hope you are better. Have you any objection to putting your name to Flower's certificate for the Royal Society herewith enclosed? It will please him much if you will; and I will go bail for his being a thoroughly good man in all senses of the word, which, as you know, is more than I would say for everybody." Five years later Huxley, whose tenure of the office of Hunterian Lecturer while Flower was "Conservator" of the Museum had increased the friendly regard and mutual respect of the two in no common degree, wrote to him from Jermyn Street, June 7 :-

\section{Private, Confidential, Particular.}

My DEAR Flower-I have written to Quain to tell him that I do not propose to be put in nomination for the Hunterian Chair this year. I really cannot stand it, with the British Association hanging over my head. So make thy shoulders ready for the gown, and practise the goose step in order to march properly behind the Mace, and I will come and hear your inaugural._Ever yours,

T. H. HuXley.

The choice of the Council fell on Flower, as Huxley had anticipated. What occurred is told in the following letter to his mother :-

Now I must tell you something about myself. You probably know that when the Hunterian Museum was placed by the Government in the care of the College of Surgeons, one of the 
conditions attached was that a course of lectures on Comparative Anatomy should be given annually, illustrated by the preparations. This was the origin of the professorship, which Owen held for more than twenty years, in addition to the Conservatorship of the Museum. It was afterwards thought that the two offices were incompatible; at all events it was thought advisable to separate them, that the Conservator might give his undivided attention to the Museum. So Huxley was appointed Professor, and has given the lectures ever since I have been Conservator. Now he finds that he can go on no longer, having so many other engagements, and has sent in his resignation. At the Council meeting last Thursday candidates had to be put in nomination, as the election takes place at the next meeting, July 7 . Before the meeting the President called on me to ask whether I would undertake the office if I were put in nomination? I told him that I was not particularly anxious to do it, but that I would leave it entirely in the hands of the Council, and reminded him of the former resolution, etc. Well, next day he told me that I had been proposed and seconded in words such that "my warmest friend, if he had been present, could not have wished anything more said," and that no one else was even thought of. So the appointment is virtually made, though it will have to be confirmed at the July meeting. The duty consists of giving eighteen lectures in the months of February and March, and the subject being a wide one, I can very much choose what branches of it I take up. The lectures each year have to be different, at least they must not be repeated for some time. I think it will do me a great deal of good on the whole, as I shall have to put my knowledge and ideas in a definite shape. . . . If I had got my book out first I should not have hesitated at all, but I hope to be able to work them somehow or other together.

The demands upon his time and brain were already becoming severe. Writing to his mother in April 1869, he says :-

We have now a little respite from the incessant occupation of last week, just enough, however, to have leisure to become aware 
of the increase of work of various sorts that keeps accumulating around. Life is a combat with a hydra-headed monster-when one head is disposed of two seem to spring up in its place. Not that the disposing of them is, as a general rule, by any means an unpleasant or painful process, rather the contrary. But there is so much of it. Now they are asking about that book of mine. Macmillan has just sent me an invitation to dine on May $\mathrm{I}$, and compare notes with the other authors of the series, and I have nothing satisfactory to report in the way of progress. What a contrast to the life Professor van Beneden leads at Louvain! A lecture from 8 till 9 in the morning, and after that nothing to do but what he likes; no society, no distractions. His ten days in London was a great change, and he enjoyed it much. . . . Above all, he was surprised at the cultivation and charm of English ladies, and to hear them talking about science and art and at the same time attending to their family and household affairs. But then he saw favourable specimens in Mrs. Smyth and her daughters. It was very curious. One day he asked me if I could tell him about an English lady who had published some drawings of small marine animals, which had interested him extremely, but of which he had not been able to find any further information. So I took him one evening to Inverness Road, where he found all the original drawings and specimens, which they have let him have to take back to Belgium to work at.

The drawings in question were by Ellen Toynbee, sister of Flower's wife.

His inaugural lecture at Lincoln's Inn Fields took place on February 16, 1870, before a distinguished audience. He declared that had John Hunter's papers been preserved they would probably have proved the most valuable contribution ever made by one man to the science of Comparative Anatomy. Passing to the present, he affirmed his belief that the Darwinian hypothesis was now firmly 
fixed as the basis of future research, and that science, which was the handmaid of truth, could lead to nothing opposed to the best and highest instincts of mankind. Owen and Huxley were both present among the audience. His first course of lectures (on the "Anatomy of the Mammalia") followed, and continued through February and March. These formed the substance of his Osteology of the Mammalia, published late in the year, and in a second and third edition in 1876 and (with the collaboration of Hans Gadow) in 1885. It was not every one who could have succeeded in interesting audiences used to Huxley's lectures. But Flower not only did this, but developed the subject-matter of the first course, for the use of future students, into a complete guide to the bony structure of the mammals, illustrated by more than a hundred original figures. The arrangement and treatment were so complete that almost any question as to the skeleton of any mammal could be readily answered from it. In the concluding chapter the correspondence between the bones of the hind and fore limbs was considered.

Dr. Philip Lutley Sclater, F.R.S., kindly writes in regard to this book:-

Among the publications of Sir William Flower, his well-known Introduction to the Osteology of the Mammalia is one of the most useful, and has been widely employed as a text-book. In I 870 Flower gave a course of lectures before the Royal College of Surgeons on this subject, and those who were fortunate enough to be able to attend them (of whom the writer of these lines was one) will not easily forget the clear and instructive manner in 
which they were delivered, and the excellent drawings with which they were illustrated. After the lectures were over they were re-written in a somewhat changed form, so that they might serve better as a "Handbook" for students, and were published by Macmillan \& Co. in September of the same year. The Handbook, which is of convenient size, and illustrated by drawings placed in the text, met with a very favourable reception from teachers and students of zoology, and attained a large circulation. A second edition was called for and published in 1876 , and a third edition appeared in 1885 , in preparing which Flower, being at that time overburdened with work, obtained the assistance of Dr. Hans Gadow, F.R.S., of the University of Cambridge.

As regards the general scheme of this excellent piece of work, it need only be said that, after a general chapter on the classification of mammals, the author discusses the skeleton and its component parts in separate essays, pointing out the modifications in the different organs which take place in the various members of the series, and concludes with a chapter on the correspondence between the bones of the anterior and posterior extremities, which has always been a favourite subject of discussion. The whole work, it may be truly said, although it is very difficult, if not impossible, to avoid technicalities in writings of this character, is compiled in plain and understandable language, and will no doubt long continue to serve the useful purpose for which it was intended.

The subjects chosen by Flower for his Hunterian lectures for the next twelve years illustrate the course of his own personal investigations in the field of zoology. It will be noticed that they all deal entirely or mainly with the history and structure of mammals, and that five are concerned with the natural history of the highest of all mammals, namely, man. In I87 I he lectured on the Teeth and Allied Organs of Mammalia, in 1872 on the Digestive Organs of the Vertebrata, in 1873 on 
the Osteology and Dentition of Extinct Mammalia, and in 1876 on the Relation of Extinct to Existing Mammals. From 1877 to i 880 he dealt with the Comparative Anatomy of Man. In I88I he lectured on the Anatomy, Physiology, and History of the Cetacea. In the following year he took for his subject the Horse and its Allies; and in the last course he endeavoured to classify man in a series of lectures on the Principal Types of the Human Species.

In 1879 he received the distinguished honour of being unanimously elected President of the Royal Zoological Society. The Marquis of Tweeddale, who had held the office, having died, the question of appointing his successor was not without difficulties. Hitherto the office had usually been conferred by the Fellows of the Society on one of their number distinguished, not only for his interest in the Society's work, but also for high rank. But on this occasion the tradition of electing a peer to be president was departed from, and Flower received the office by a unanimous vote. He was regularly re-elected for twenty-two years, and during that time never failed to attend and preside at the meetings, unless prevented by unavoidable circumstances of work or health.

His wife remembers how continually she had to decline invitations to dinner because it was a Tuesday, the evenings of the Society's scientific meetings; and however interesting the occasion promised to 
be, it was still the rule to decline, the first duty being to the Zoological Society.

As showing the interest which his lectures aroused among men of "all-round " accomplishments who were not specialists, we may take the following portion of his correspondence with the Duke of Argyll. They refer to various lectures and papers of Flower's, and are fair specimens of his epistolary style :-

The Duke of Argyll to Professor Flower

October $2 \mathbf{1}, \mathbf{1} 878$.

I think I heard you say that the skull of the Tasmanian is the only skull on which you could pronounce with certainty as to the race to which it belongs; that it is so separate from all others by marked characteristics that it can never be mistaken. On the other hand, I think I have heard you also say that there is no skull, however exceptional, which cannot be occasionally matched by individual skulls among other races.

May I ask whether this last generalisation holds good of the Tasmanian skull as well as of others? That is to say, whether skulls with all the characters of the Tasmanian (square orbits, etc.) do not occasionally occur among the higher races? Among the Australians especially I should suppose that, if anywhere, individual cases would occur of skulls of the Tasmanian type. The race which inhabited Tasmania must, almost certainly, have originally crossed from Australia. It would be very strange if they had left no trace behind them on the large island.

I think you read a paper on the subject at the late Belfast meeting. If you could send me a copy I should be very much obliged to you. 


\section{Professor Flower to the Duke of Argyll}

39 Lincoln's InN Fields, W.C.

October 26, 1878 .

The Tasmanian skull is by no means the only one which can be distinguished from all others. The Eskimo, for instance, is certainly quite as characteristic. I do not think that a genuine Eskimo skull could possibly be mistaken by any one conversant with the characters of the race for one of any other family of men. The same may almost be said of the Australian, the Andaman, and, in fact, of many other races which have retained their purity.

As in everything else of the kind, very much depends upon the skill and powers of observation of the person examining the skull-skill and powers which only become developed by long familiarity with the objects examined.

The possibility of finding a skull exactly similar to that of a typical Tasmanian among people of other races, I could no more believe in than I should in that of finding a man with the thick lips, woolly hair, and black skin of an African negro born in an English village of English parents! You might look through any number of European skulls and certainly would never find one which could be mistaken by a competent observer for either a Tasmanian, Australian, Eskimo, or Andaman, and I might even say Negro, American, Polynesian, Chinese, etc. I fancy such statements must have arisen among people who have only considered some few points, as the comparative length or roundness of the cranium, etc., and not the tout ensemble of the characters of skull and face.

It may have been said, for instance, that the Eskimo has a very long head (index $7 \mathrm{I}$ ), the Lapp a very short head (index 82 ); you may find among Europeans (a much mixed race) skulls as long as the former and others as short as the latter, therefore the character is of no value-this conclusion is a complete mistake, the European skull which may resemble the Eskimo in its length will differ from it in numbers of other points. We are still, however, very far from an exhaustive knowledge of these subjects. I am only a beginner myself at Craniology, but I am 
strongly impressed with the idea that race characteristics are as strongly indicated in the bones of the cranium, including those of the face (hitherto much neglected), as they are in the external features, colour, hair, proportion of limbs, stature, etc.; but at the same time none of the varieties amount to what, speaking zoologically, I should call "specific." A well-known advocate of the "polygenitic" view of man's origin cites the skull of a New Hebridean in his collection, declaring that such a skull has such strong specific characters as could by no possibility be found in an English graveyard. I perfectly admit the premises, but not the conclusion, illustrating my objection by saying that it would be equally impossible to find a cranium having the characters of a bulldog in the burying-ground of a kennel of foxhounds!

The relation of the Tasmanian to the Australian race is a great difficulty at present, involving the question of the importance of hair as a race characteristic ; by the hair the Tasmanians are allied to the Melanesians and Papuans, and separated from the Australians. These may have been the primitive inhabitants of the whole of Australia, and the Australians (from wherever derived) may have occupied that great continent at a subsequent date, driving out the woolly-haired people, who survive only in the islands, and of whom traces are still said to remain in some parts of Australia. But we have not yet the data to discuss this theory. Among collections of Australian skulls, we find some tending to the Tasmanian type, but whether these belonged to individuals having curling hair, and other Tasmanian characteristics, or even came from the localities where that race might have been supposed to linger, we unfortunately do not know.

As I hope, whenever opportunities permit, to continue to work at these questions, I shall be much pleased if at any time I can be of use to your Grace in regard to them.

The Duke of Argyll to Professor Flower

Argyll Lodge, Kensington, October 28, 1878 .

Many thanks for your very interesting letter, which will be of great use to me. I see in the paper you sent last week that 
craniologically the Tasmanian has many strong affinities to the Australian, such as to make it quite probable that the kinship is not distant. As regards woolly hair, I confess I have no belief in its even approaching a specific character.

But indeed, as regards the specific unity of the human race, tested by all zoological arguments universally admitted as applicable to other animals, the case seems to me so strong that the Polygenists have not a leg to stand upon.

You mention the native "dingo" or Australian dog. Can you tell me whether anything is known of its origin? There is no native $\operatorname{dog}$ in Australia; that is to say, no non-marsupial mammal in the native fauna of Australia, Man must have brought the "dingo" with him, as he naturally would do. I don't know whether the Tasmanian had any dog?

I am very sorry to hear that you are still so unwell. I hope I don't give you too much trouble in asking you these questions.

\section{Professor Flower to the Duke of Argyll}

39 Lincoln's InN Fields, W.C., October 29, 1878.

I think that there can be no doubt about the native dog or dingo having been introduced by man into Australia, although there is no direct evidence upon the point. Nearly all the islanders of the South Seas, including the New Zealanders, had their domestic dogs when first discovered by Europeans; but the Tasmanians had none. This seems proof of their long and complete isolation from the rest of mankind, especially as there was nothing, either in the climate or nature of the people, antagonistic to dogs; for when these animals were introduced by the English settlers they soon multiplied, and nearly all the wild natives, already before their extinction, had become possessed of and made companions of them.

The strongest, and in my mind fatal, objection to the polygenist view is that none of its advocates have been able to agree upon the number of species into which man should be divided. Some say two, some three, some twelve, some sixteen, some sixty. Surely if the divisions were so trenchant as they assert, 
there would by this time be some approach to a concord on the subject.

I have just received a quantity of skulls and bones of the Andaman islanders, a most singular race, combining woolly hair with round heads and other cranial characters not found in any other Ulotrichi. I want to work out their affinities, as I think they may throw some light upon the classification of man, or perhaps dispel some false light, which is the next best thing; but I am disabled at present, having had to undergo a surgical operation, and shall be confined to the house for about another week.

I shall always, now or afterwards, think myself fortunate if I can be of any use to you in your researches in these subjects, more especially as, if you will allow me to say so, I am very grateful to you for all that you have said and done of late in reference to public and international affairs. When this flood of feeling, which has taken possession of the public mind, has subsided, with what satisfaction will it be felt and recorded that there were voices, and those not of the least wise or able of our country, raised in protest and warning against national folly and injustice.

\section{Professor Flower to the Duke of Argyll}

LinColn's InN Fields, February I6, 1883.

I think there can be little doubt that the rudimentary pelvis and hind limbs of the whale are parts that are dwindling away in consequence of having lost their function. Recently Professor Struthers of Aberdeen has described very minutely these structures in a number of examples which he got the whalers to bring him from the Northern Seas, and he has shown not only three distinct bones, representing pelvis, femur, and tibia, with wellformed joints and ligaments connecting them, but, what is more remarkable, a complete set of muscles, the counterpart, in a reduced and functionless condition, of those found in mammals with perfect hind limbs. His observations are published in the Journal of Anatomy and Physiologv, I88I.

All this seems to confirm many other indications that the Cetacea were originally terrestrial mammals which have been 
specially modified and adapted for an aquatic life. The fore limbs in the same way retain all the elements of the typical mammalian limb, not only in the bones, but also in muscles no longer functional, and developed in different degrees in different species. The foetal teeth of the whalebone whales, the rudiments of a hairy covering, and especially the organ of smell, all point in the same direction. The latter is very conclusive; it is not, as in fishes, adapted to perceive odorous substances floating in the water, but, as in land mammals, is only acted upon by the air as it passes by in the process of respiration; but as in this form it can be of very little use to an animal passing its existence almost entirely under water, it has become quite rudimentary, and in many of the dolphins and porpoises all trace of it is lost.

Among the different groups of Cetacea there are various stages of perfection of the pelvic organs. In one, the Tlatamista of the Ganges, there appear to be none; in the common dolphin, porpoise, etc., there are only simple styliform pelvic bones, but no trace of anything that can be called a hind limb. Among the large whales all have the pelvic bone, some a mere rudimentary nodule of cartilage representing the femur, some with a larger bony femur, some with both femur and tibia, with muscles, etc., as just mentioned.

The seals afford no help to the origin of the whales; their resemblances are analogical; they have all complete hind limbs and pelvis (though small) as in ordinary mammals. They swim by their hind legs, the tail being rudimentary; the whales swim by the greatly developed tail, the hind limbs being rudimentary. I do not believe that a Cetacean can be a further stage of a seal, as some seem to fancy, because when an animal had obtained such a perfect adaptation to its mode of life as a seal has, by means of (its) hind limbs being so specially modified, it is difficult to imagine their function being transferred to the tail. On the other hand, it is far more likely that an aquatic animal with a large tail already of some use in swimming, like a beaver or an otter, might have this organ expanded and perfected, when the legs would gradually cease to be of use the more exclusively aquatic the animal became. There are several points about the anatomy of the Cetacea which make me think they are rather allied to the 
Ungulata than the Carnivora, and that there is some truth in the old expression - sea-hog or sea-pig, Meerschwein, Marsouinapplied to the porpoise itself, I believe derived from Porc-poisson.

Their origin is, however, at present a complete mystery, and palæontology throws very little light upon it. The earliest known Cetaceans, the Gengloda of the late Eocene, are still imperfectly known, although certainly in some points about the dentition and cranium more generalised mammals than any existing forms; of their limbs we know next to nothing. The Sirenia (Dugongs and Manatees) form a totally distinct type, with nothing to do with either Cetacea or seals, except in adaptations to similar conditions of life-the mere resemblance of a bat to a bird. Their pelvis is also very rudimentary, and no existing species has any trace of hind limb; the extinct Holitherum, however, had a little pelvis and small styliform femur. I cannot form the slightest guess at present as to what other mammals they are related to. Palæontology does not help us here either; but when we consider the enormous advances that have been made in this branch of the subject as regards certain groups - the Ungulata of North America, for instance-within so few years, we can hardly say what may not be still to be discovered.

I think that I have answered all your questions as fully as I am able.

\section{Professor Flower to the Duke of Argyll}

June 8, 1883 .

I think that I was able to answer satisfactorily the question you once asked me, as to whether the rudimentary hind limbs were disappearing or incipient structures; they must certainly be the former. Limbs always commence by their most distant or superficial parts appearing just as folds or outgrowths of skin - this is the only form in which they could be of any use to the animal-afterwards they get strengthened by the internal structures and connected with the skeleton. In all the higher vertebrates they are developed in this way.

In disappearing the process would naturally be the reverse. The outer part would go first, or when once so shrunken as to 
CHAP.

be of no inconvenience to the animal, one can imagine rudiments of the proximate bones remaining for a very long time after they had become functionless, as in the whalebone whales.

These animals are full of points of interest, and furnish more arguments than any I know for the theory of transmutation.

\section{The Duke of Argyll to Professor Flower}

$$
\text { June II, } 1883 \text {. }
$$

I am very glad if my questions have directed your attention with definite results to the curious problem as to the prospective or retrospective character of rudimentary organs in the Cetacea as well as in other animals.

I am not sure that I quite understand your argument. But it will be best understood by seeing specimens, and I should be very glad some of these days to attend at the Museum and see any that you could show me.

In the processes of ordinary generation it is quite clear that the future organs must be in the germ, and must in time have incipient parts, whether they are visible or not. Transmutation involves the supposition that the whole line of future development must be similarly present in all germs-potentially at least with beginnings of actual structure, visible at certain times. Aे priori, therefore, one would expect such structures to appear in any complete series of organisms. If they do not appear, I suppose we must take refuge in that convenient "bolt-hole"-the "Imperfection of the Record."

That all limbs should begin with integumentary foldings, unsupported by any internal structure, seems very strange.

\section{The Duke of Argyll to Professor Flower}

June 30,1883 .

I have read with great care your most interesting lecture, so far as published [the lecture on "Limbs"].

I see that the principle for which I am looking as probably to be found in Biology is virtually involved in a fact which has long been recognised in Comparative Anatomy, and which you specially dwell upon as exemplified in the whales. That fact 
being this : that in all cases of highly specialised organs they are nothing more than an abnormal development of rudimentary structures always to be found in the generalised forms. Thus you trace the baleen, which is a most peculiar specialisation, to a development of certain "papillæ" which are to be found in the palate-structure of all the mammalia.

I need not say that this (so far as it goes) agrees with my idea that, on the evolution hypothesis, we ought to find structures on the way to functional importance, as well as structures on the way to final disappearance and extinction. Of course mere papillæ are mere germs, but they are germs with a "potential" value, and are, as it were, the roots of growths which could not have arisen without the previous establishment of the roots.

Probably there may be other cases when the roots will be found "sprouting" and giving rise to growths which are of comparatively slight functional use. Such may be the case with those Cetacea which I saw, in which the baleen was present fairly developed, but still in a minor degree.

May I ask whether the palatal papillæ are really present in all mammalia?

Professor Flower to the Duke of Argyll

Royal College of Surgeons of England, LINCOLN'S INN FIELDS, W.C., July 2, 1883 .

I do not think that it would be correct to say that the "palatal papillæ " are really present in all mammalia, as the palate is sometimes quite smooth. But the tissues of which they are formed are there.

In the rough diagram I enclose the red part represents the vascular membrane covering the bone of the palate, corresponding to, and in fact continuous with, the true skin, derm or corium, which covers the external surface of the body. The blue is the non-vascular epithelial layer, corresponding to the epidermis of the surface, which is modified into nails, hair, horns, etc., in particular regions.

In No. I the surface is smooth. In No. 2 small ridges (there seen in section), as in the human palate, are shown. In No. 3 
the ridges are larger, as in the dog, pig, etc. In No. 4 they are still larger, and develop conical papillæ on their free surface, as in the ox and giraffe (the "forked" end of the lamina is only diagrammatical, as it is impossible in such a view to show a view of papillæ side by side along the edge). In No. 4 we see the evolution of whalebone in its simpler forms-the ridges or lamina longer, the papillæ greatly extended, and the epithelial covering "mere differentiations of a continuous but not very conspicuous epiplastic thickening, which is probably the rudiment of a lateral fin." In the chick "the limbs appear as outgrowths from a slightly marked lateral ridge which runs on the level of the lower end of the muscle plates for nearly the whole length of the trunk."

The progress of development of an organ before it becomes of actual use to its possessor always seems to me one of the great difficulties in endeavouring to account for such progress by the principle of natural selection alone; such rudimentary limbs, however, mere flaps of skin, would, especially when muscles are developed within them, soon aid in progression through the water, and then might become defined in form, and strengthened by the growth of supporting structures within, first as mere fin rays, afterwards extending inwards as the bones which connect the outer part of the limb to the axial skeleton. This is my idea of the process of growth or development of the limb of a vertebrate animal, and it is pretty well borne out by what we see in the adult condition of many fishes which possess the distant but not the proximate part of the member-the reverse condition to that of the whales.

\section{The Duke of Argyll to Professor Flower}

INVERARAY, January 13, 1884 .

I write a line to congratulate you on your removal to a wider sphere of usefulness, a change in which the public will gain more largely than yourself. ${ }^{1}$ I have been reading over again your lecture on whales. I recollect when I first asked you the question

1 His appointment as Director of the Natural History Museum. See next chapter. 
whether the pelvis was a relic or only a rudiment you replied that this was a question which nobody could answer.

You seem to be quite sure now, and I think you are very likely right. But I am not sure that I follow the argument that limbs growing from the inside are inconceivable. As a fact they may all arise externally. But the internal growth to meet the external excrescence, and to support it, is in itself quite as difficult to conceive as the opposite or reverse process. This is all a matter of evidence as to fact, and not a question of greater or less difficulty of conception. I do not know what amount of evidence you have that hind limbs do always begin in internal appendages. You can't get rid of the theoretical difficulty that every organ must begin before it is fit for use ; and this applies equally to all organs, whether they be internal or external. If all organic beings have been developed gradually, there must be innumerable specimens of incipient as well as of decaying structures. Yet they never seem to be recognised or pointed out.

\section{Professor Flower to the Duke of Argyll}

39 Lincoln's InN Fields, W.C., January 28, 1884 .

I will bear in mind your criticism about the limbs. There is still much to be done in the way of working out their embryology in detail. Balfour says, speaking of the elasmoid fishes, "The two pairs of limbs appear as being the nearest to the parent stock -the youngest because the least aberrant from the original mammalian type, so far as limbs are concerned. If so, how does this doctrine apply to the appearance and development of whalebone as opposed to teeth? Clearly as regards thein, the whalebone whales are the most aberrant, the most differentiated, from the original type. Whilst, as regards the limbs, they are the least differentiated, the least aberrant.

You showed me some whale skeletons in which the whalebone was combined with teeth in full functional use, some in which the whalebone was quite subordinate as regards use. Are we to conclude that these are on the road to be full whalebone 
whales, or are these again cases of aborted and dying-out remnants of growths which were once more fully developed?

As regards functional use, I can't believe that small fringes of whalebone are at all required for the capture of ordinary fish-prey. Whalebone is a marvellous adaptation for the capture of minute organisms, but for this alone; and therefore the half-whalebone whales look very much like creatures having a special development beginning before its utility, or at least its necessity, has actually arisen. Until we can come to some conclusion on these questions we may be quite sure, indeed, of the general facts of evolution, but we can know nothing of the tracks which it has followed. In marine animals, if anywhere, the record may be comparatively complete, and in the whales we may possibly recognise the lines the development has followed.

\section{The Duke of Argyll to Professor Flower}

August 7, 1887.

Can you tell me whether, anatomically, there is any physical cause why monkeys should not be able to utter articulate sounds as well as parrots?

You may have seen Max Muller's book on the Science of Thought. He makes speech the one great distinction between man and the beasts, and says that without speech thought is impossible. If by speech he means conversation, of course that involves thought. But I maintain that thought comes before speech-the latter being only the embodiment of thought.

But he has a passage indicating that physiologically speech is impossible to the Quadrumana from the absence of all adapted organs. I don't know how this is. I was struck lately with the human movements of a monkey's tongue and its "licking its lips" in expectancy of food. Some vocal cords it must have, though probably less complete than man's.

Professor Flower to the Duke of Argyll

Riederalp, August 14, I887.

Your letter of the 7 th has reached me here very lately, so I have not been able to answer it before. 
I quite agree with you that thought must come before speech, at least before anything like conversation. Knowing what slight modifications in structure are often associated with enormous differences in function and vice versa, it would be very rash to say that an ape's vocal organs (so closely resembling man's as they are) might not under the proper stimulus be developed or cultivated into producing articulate sounds. Some of the higher apes, especially the gibbons, have a loud and very human-like voice, and the remarkable chimpanzee now at the Zoological Gardens, called "Sally," does something that sounds very like talking.

But I have no doubt but that the question you put to me would be answered differently by different persons whose knowledge was based upon precisely the same data, according to the bias of the mind to see resemblances or differences.

This is at the bottom of the whole of the "Man and Ape" controversy, and we shall never get to the end of it.

\section{Professor Flower to the Duke of Argyll}

$$
\begin{gathered}
\text { British Museum (Natural History), } \\
\text { Cromwell Road, London, S.W., } \\
\text { October 6, } 1887 .
\end{gathered}
$$

The description which you have sent of the strange bird is so full and graphic that there can be no doubt about it. It is the roller, Coracias garrula. It is a bird of Eastern Europe, but many instances are recorded of its occurrence in Scotland, and it is included in all the lists of British birds.

Your specimen may be in immature plumage; the "chestnutred" back is quite right. The pictures of the bird in books are generally over-coloured.

\section{The Duke of Argyll to Professor Flower}

INVERARAY, ARgYlLSHIRE, September 26, 1888 .

I have just come home from a drive in which I have made a grand discovery - organic remains in one of the quartzite beds of this neighbourhood. 
For fifty years I have passed and repassed this rock and never seen its contents. Close to the road and to the shore, so that I have passed it on one side in boats and on the other side in carriages. So true is it that one can only see what the mind leads one to notice. My late cruise in the north, where a fere of the quartzites are fossiliferous, led me again to examine the few beds of similar material among our mica slates. A road surveyor had broken off some fresh surfaces to make "metal" for the road. I saw it freshly broken, and the very first fragment revealed what I take to be plant-remains-possibly fucoid-in red oxide of iron, beautifully contrasting with the pure white silicious grains of the rock.

The fossil form consists of small tubular branches, with berries or seed-vessels at frequent intervals, seeming to me to indicate higher vegetable forms than fucoids. The seed-vessels are on small stalks. I don't think I can be mistaken, for under a pocket-lens I can see vascular structure on the walls of the tubes, where they are broken so as to show the inside.

Will you send me some small example of the "Fucoid Bed" of the Sutherland quartzites for comparison. ${ }^{1} \quad$ These I have never seen, but I know the worm-casting fossils of Sutherland quartzite well. The "Fucoid Bed" I have never met with, and don't know its appearance.

\section{The Duke of Argyll to Professor Flower}

INVERARAy, ARgYLLSHIRE, September 28, I 888 .

I have had a careful examination of the rock whence I got the first specimen of plant-remains two days ago. The result is of great interest. The plants are only well seen on a few weathered surfaces where structure comes out clearly. But the clue, once given, leads farther. We recognise the ferruginous spots which mark the spore-cases, or capsules, all through the quartzite bed, and passing from the top of it into pure mica schists, where they are seen in quantity, spotting the rock with innumerable spots of red oxide of iron.

1 (We have no examples.-W.H.F.) 
This interpretation will, I suspect, hold good in many localities where the origin of such spots was unknown. I think the plant was a moss. But if so, very different from any existing moss, so far as I know. The flower, or what stands in the place of a flower, a sort of leafy or fibrous capping to the spore-vessel, is seen in only one specimen I have yet found. But the stalks, or branching stems, are all apparently tubular. In some cases where the tube has been opened by the rupture of the upper side, the internal wall exhibits a striated surface like a dried vascular tissue. I am setting about making a regular collection.

Tell Etteridge. Would he like to come down to see them? I should be delighted to see him. But I leave this to-morrow for a few days, returning here on Wednesday next. If he could come down to Greenock by the night train from London on Tuesday, he could catch the steamer Lord of the Isles, by which I return myself. It is the last day of that boat for the season, and takes us here at 2 P.M.

This discovery is an important one. It bears on a peculiar form of primeval vegetable life and on the phenomena of metamorphism, which are so obscure.

\section{Professor Flower to the Duke of Argyll}

\section{British Museum (Natural History), Cromwell Road, London, S.W., February' 2, 1893.}

In the Museum of the College of Surgeons is a beautiful set of models in wax of the electric organs of the torpedo, which were made by order of one of the Grand Dukes of Tuscany for Professor Owen while he was Conservator of the Museum, being, I believe, exact copies of those you saw at Florence. I do not know whether you have yet received Professor Ewart's memoir on the electric organs of the skates? It is just published in the Philosophical Transactions.

In Nature of January 19 there is an article by Gustav Fritsch of Berlin on the electric organs of various fishes. These all tend to show that these organs are modifications of some other structures which existed previously in the animal, but how 
the modification commenced is as difficult as ever to understand.

Romanes is still in Madeira. He is not able to do any work, but a letter from his wife this morning to mine says that he is greatly improving in health.

I hope that you read some account of the meeting on the 2 Ist for the Owen Memorial. It was generally considered very successful; the best report was in last week's Nature. 


\section{CHAPTER IX}

APPOINTMENT TO THE NATURAL HISTORY MUSEUM

At the close of the year 1883 Sir Richard Owen, being then in his eightieth year, placed his resignation of the post of Superintendent of the Zoological Departments in the hands of the Trustees of the British Museum, and retired to the pretty cottage near the Sheen Lodge in Richmond Park, lent him by the late Queen, where for nine years more he continued to enjoy the calm and beauty of the congenial surroundings of his new home, until he died, literally of old age, on December 18, I892.

The appointment of his successor lay, according to statute, not with the general body of the Trustees of the British Museum, but with three principal members of that eminent body, the Archbishop of Canterbury, the Lord Chancellor, and the Speaker of the House of Commons. Among the other Trustees of the institution were the King, who as Prince of Wales took a keen interest in the welfare of the great national institution in the control of which he was associated, the Duke of Argyll, and Lord Walsingham. The three chief 
Trustees were Archbishop Benson, Lord Selborne (Lord Chancellor), and the Speaker of the House of Commons, now Lord Peel.

There seems to have been little hesitation as to their choice, though Sir Edward Bond ${ }^{1}$ seems to have entertained some doubt as to whether Flower wished to leave the Hunterian Museum, and he was right, for Flower was much attached to it and to his home in Lincoln's Inn Fields; he also felt leaving his great friend Sir James Paget, who urged him to remain, even offering to get the salary increased if he would. Flower felt that the British Museum had the strongest claims. From his boyhood he had an enthusiasm for this national institution, so that when the opportunity came to serve it he had no hesitation in applying for the post. ${ }^{2}$ While expert opinion, including that of Sir E. Bond and of Huxley, was earnestly in Flower's favour, the prospects of his appointment soon took almost the form of certainty. On December 3, I883, Huxley wrote :-

1 The Chief Librarian of the British Museum.

2 Among "things not generally known" is the following. In I866 twenty-five of the most distinguished representatives of all branches of science in London presented a memorial to the Chancellor of the Exchequer, praying that "the administration of the Natural History Museum should be separated from that of the Library and Art Collections of the British Museum, and placed under one officer, who should be immediately responsible to one of the Queen's ministers." In other words, they desired to terminate the control of the Trustees of the British Museum. Among the memorialists were George Bentham, William Carpenter, Professor Huxley, Sir Joseph Hooker, Lord Lilford, Professor Alfred Newton, Professor Andrew Ramsay, Mr. Alfred Wallace, Lord Howard de Walden, and Canon Tristram. Flower, when invited to sign this document, declined. Eighteen years later he became the servant of the Trustees. 
"Privatissime."

MY DEAR FLOWER - I was very glad to get your letter, and now see my way more clearly.

I have just come from a meeting of the Finance Committee of the British Museum, and can report that affairs are marching. Owen has readily assented to the proposal of the Trustees, and the vacancy will soon be declared.

Next I broached the question of the house for the Superintendent, and this was so well received that I have no doubt that the standing committee to whom we report will urge strongly on the Treasury the propriety of giving one-that is, of building one.

They have already fought the battle for the keepers, and the Treasury obstinately refused; but I do not despair on that ground. It would be everything to get Childers' mind properly impressed on this subject, but unfortunately I have never met him, though I believe I know every other member of the Government.

Unfortunately I do not drink beer, or I would go so far as to bet you a pint that you are in office in three months.

The formal appointment as Director was not sanctioned until the close of June I884, some six months after Huxley wrote; but he did not "speak without the book," to quote one of his own phrases, as Flower actually began his work at the Natural History Museum on March I4, I884.

Leave for the change of title from Superintendent to Director was obtained from the Trustees at a meeting in March. But Treasury sanction had to be obtained not only for this, but for the increase of the stipend from $£ 800$ to $£ 1400$, at which it was ultimately fixed. It may be added that Sir Edward Bond was among the first to urge that the post should be properly paid, though a less zealous or less generous nature might have feared that the 
post might be in some measure a rival to his own.

The following letter from Sir Edward, then Chief Librarian of the British Museum, a post which was and is equivalent to that of head of the great national institution, was received on June 22, 1884 :-

Dear Professor Flower-I have the great pleasure of reporting that I obtained the Archbishop's signature to your appointment as Superintendent of the Natural History Museum this afternoon, and that I expect to have the addition of the Chancellor's name to-morrow. The appointment cannot be acted upon until Treasury sanction has been received for its being made, under Clause VII. of the Order of Council providing for the case, and I hope to obtain on Saturday morning instructions from the Trustees to apply for it.

I need hardly add that the completion of the appointment will be a matter of the utmost gratification to me personally, and I fully believe to all who take interest in the Museum.-Very truly yours,

EDw. A. Bond.

The proposal that the Director should have a house attached to the Museum was partly due to the advantage which every one had noted in the fact of. Flower's residence next door to his work in Lincoln's Inn Fields. He was able to step into the Museum at all hours, and often almost lived there. The idea was placed before the Government not by Mr. Childers but by Lord Sherbrooke, but was negatived by Mr. Gladstone, who, in an elaborate and curiously didactic letter, dated from his own official residence in Downing Street, proved convincingly the iniquity of granting official residences 
in general, and of attaching them to Museums in particular.

The post to which Flower was now appointed was one for which, both by instinct and training, he seems to have been intended by nature.

While the Hunterian Museum and the work there had primary and practical reference to man, to the study of whose form and the well-being of whose body it was destined by express intention to contribute, the scope of the Zoological Department of the British Museum was as wide as life itself. Neither was it limited to the collection and setting out of the forms of life of to-day or of the laws to which they conform, whether of plants or animals. The life of forgotten worlds and of extinct forms was also included, while the inorganic elements of the world's structure were represented in the portions devoted to mineralogy, which have attained to such remarkable development under the direction of the present Keeper of Mineralogy, Mr. L. Fletcher, F.R.S.

Writing to the Duke of Argyll just after his appointment on January 28, 1884, Flower says :-

I beg to thank you for your kind letter about the British Museum appointment. I shall be very sorry to leave this Museum (the Hunterian) where I have worked for twenty-two years, but the other is a very important post, as much of the position and progress of Natural History in this country may depend upon the good arrangement of that grand collection. It is therefore a great responsibility. It is, however, most gratifying to me to 
find that the appointment has been received with so much approbation by all who are interested in the subject.

The general approval to which he refers probably relates to the way in which his appointment was received by the public, which found unmistakable expression in the press. It was confidently stated that "no more judicious choice could have been made, nor one more popular with the public and men of science. Professor Flower has for over twenty years devoted himself to the promotion and extension of the unrivalled anatomical collection in Lincoln's Inn Fields, and this by his efforts has reached a condition of almost perfect efficiency. There is no doubt that now, when he has accepted the office at South Kensington, where his intellect will have much larger scope for exercise, he will do much to make the Department what it ought to be, the most renowned and popular in the world."

The Times concluded its leading article on the appointment by expressing an opinion that Flower would not find his Directorship "altogether a bed of roses." Such a hint was clearly not given without cause. The character and courtesy which at once disarmed opposition and replaced misgivings with confidence enabled Flower to dispel any feelings which might have conduced to bring about such a position as the Times feared might arise. But the previous history of the creation and working of the Zoological Department of the British Museum explains in a measure the words of the article. 
The collections of Natural History of the British Museum had been kept at Bloomsbury. Neither the specimens nor the accommodation for them were at all worthy of the National Museum. But the subject of Natural History had not, until the second quarter of the last century, taken the place either in the esteem of men of science or in the interest of the public which it was destined to occupy. "A scientific naturalist who lived in England in the second quarter of the last century may be accounted a fortunate man," says Mr. J. Willis Clark, an old and valued friend of Flower's, in his chapter on Richard Owen included in his recollections of Old Friends at Cambridge and Elsewhere. "On the one hand was the vast field of the universe, undivided, unallotted; on the other a public eager for instruction."

The man who came first upon the scene, and had the good fortune to be ready just when he was wanted, was Richard Owen. It is somewhat the fashion to disregard what Owen did in the light of what he did not do, and to allow his failure to appreciate the value of Darwin's discovery of the principles of evolution, and his intense absorption in his own personal position in the estimation of "a public to which he had long been accustomed to act as the leading and almost the sole exponent of zoology, to obscure one of his great services to the practical promotion of that study.

It has been said that appreciation is one of the 
greatest marks of intellect. In the case in question the appreciation of Owen, which first put him in a position to make his practical suggestions to those in authority, came from Lord Macaulay. In one of his letters he says, "I am extremely anxious that something should be done for Owen. I hardly know him to speak to. 'His pursuits are not mine, but his fame is spread over Europe. $\mathrm{He}$ is an honour to our country, and it is painful to me to think that a man of his merit should be approaching old age amid anxieties and distresses." The result was that Owen was appointed to a new post, created for him, in the British Museum at Bloomsbury. "He was to stand towards the collection of Natural History in the same relation that the librarian did towards the books and antiquities, and to be directly responsible, as he was, to the Trustees."

The appointment was made in 1856 .

Unfortunately, while what was desirable was quite clearly present to those who made the appointment, which gave Owen a salary of $£ 800$ a year, they entirely forgot one of the important details which alone could have ensured success. The new officer was given no control over his subordinate officers. They were practically independent, and desired to remain so. Owen, who had always been accustomed to work for his own hand with conspicuous success, was not equipped with the power necessary to deal with a situation which would have been difficult for any one to cope with. He there- 
fore accepted the position. So far as his place as Superintendent went his influence did not greatly alter the management within the Museum. But his position gave him the power of addressing the Trustees, and through them the Government.

He used this to bring about the separation of the Natural History Museum from the collections at Bloomsbury, and its establishment on its present basis at South Kensington. Two years before Owen's appointment, Dr. Gray, Keeper of Zoology, had requested that more accommodation should be given for his department, which resulted in a small extension of the galleries. In 1859 Owen, after carefully studying the subject, laid before the Trustees all the facts as to the overcrowding, the numbers of objects stowed away out of sight, and the probable rate at which these would increase, and stated that a space of ten acres ought to be acquired at once. More than this, he drew up a plan, which he sent in with the report, which showed how carefully he had thought out the form which the building of a Zoological Museum should take. His plan was comprehensive and logical, and far better than that devised by the architect later when effect was being given to his suggestions, of which only one, the Central Hall, is retained.

Owen's idea was to have a central hall, to contain what he termed an Index Museum, to show the type characters of the principal groups of animals.

This Central Hall did find expression in the 
building ultimately raised, though Sir William Flower used it not to show types of animals, but to illustrate the working of the leading laws of evolution, a change from the concrete to the abstract, and from mere facts to the expression of law in facts, which must be admitted to mark a higher ideal. But to return to Owen's conception of what the Museum should have been. Besides the hall, he proposed that it should contain a lecture theatre, to teach orally, a large gallery for physical ethnology, by which he meant a complete series of coloured casts of all races of men-an idea which suggests that Owen would like to have had them stuffed if it were permissible, and another large gallery for the whales and great Cetacea, which, as he justly said, could only be exhibited in a National Museum on account of their size.

But his most advanced proposal was one for showing the series of nature complete in time by abolishing the artificial distinction between living and extinct animals. The history and forms of neither can logically be studied apart. The separation into zoology and palæontology is purely arbitrary. Owen had once proposed that the series should be completely intermixed. ${ }^{1}$ His modified suggestion, due probably to the separation of the staff into departments, was to make the galleries in which the specimens were exhibited adjacent or continuous. The whole conception was novel and striking. 
Scientific men recognised its value. But at first it incurred criticism from most, and by some it was ridiculed. It was too far in advance of the time. Mr. Gregory, M.P. for Galway, got it referred to a select committee, when the proposal was debated in the House of Commons, regretting in reference to its author, "that a man whose name stood so high should connect himself with so foolish, crazy, and extravagant a scheme."

In Flower's memoir of Sir Richard Owen, published in the Proceedings of the Royal Society, he notes that the division of the Museum establishment into four distinct departments, each under its own head, left the Superintendent practically powerless. Besides this, Owen was in his seventy-seventh year when the Museum was opened to the public.

Owen's first idea had been that the land should be purchased near the British Museum in Bloomsbury. Later, convinced in part by the suggestions of others, he steadily advocated its removal to a fresh and distant site. Mr. Gladstone, then Chancellor of the Exchequer, gave the scheme his hearty support. On May I 2, I 862, he moved for leave to bring in a bill to effect the change. Unfortunately Mr. Disraeli saw in opposition to it a political move which might embarrass the other side, and obtained an adjournment of the proposal. But in 1863 Parliament voted the purchase of five acres in South Kensington, an area which Owen induced the Government to increase to eight acres. But 
besides the "teaching" or graphic exhibition he had also to consider the accumulation and arrangement of that enormous stock of reference specimens which are needed, not to teach the public, but for scientific ornithologists, entomologists, or other naturalists to study. The collections were very large and important, for Owen, while not trying to enforce his own ideas on those in control of the departments and sections as to arrangement, steadily aided and encouraged acquisitions by and from all sources which he could reach or influence. In addition to the Zoological departments, there were also housed in South Kensington the mineralogical, botanical, and geological collections from the British Museum. Among these were and are many separate collections made by men of mark. It may be remembered that when Darwin came back from his voyage on the Beagle he found that though others did not care for his collection, Owen and Lyell gave him every encouragement. Among the Zoological collections transferred to South Kensington were the magnificent series of birds' skins brought from the Malay Archipelago by Wallace after his sojourn there, with the accounts of which he has delighted untold numbers of readers. Gould's humming birds are still one of the attractions of the galleries. In the Botanical department was the herbarium of Sir Hans Sloane, containing 8000 specimens, the great botanical collection of Sir Joseph Banks, and William Wilson's herbarium of British 
and foreign specimens, containing the identical plants from which the original descriptions made by Linnæus, Amblett, Jagny, Brown, and Bentham were written. The description of the matter and material taken from Bloomsbury to South Kensington belongs rather to the history of the Museum than to that of Sir William Flower. But the immense task of transfer and re-arrangement was accomplished by the able staff of the Museum in far less time than might have been anticipated.

It was not until the spring of $\mathrm{I} 88 \mathrm{I}$ that the collections were so far arranged that the public were admitted to the building; and Owen himself resigned the post of Superintendent two years later. But with all its imperfections in detail, which are due to others, and with the absence of the lecture theatre and whale gallery, the Natural History Museum stands as a monument to Owen's foresight, and as a proof of the confidence placed in him by the practical minds of the Government of the day. ${ }^{1}$

1 The Cetacean Gallery was added later owing to Sir W. Flower's representations, though not on the scale which he or Owen desired. 


\section{CHAPTER X}

THE NATURAL HISTORY MUSEUM-continued

Flower began his duties at the Natural History Department of the British Museum in March I 884 as "Superintendent," but the change of title to that of Director was made shortly afterwards, on March 14. The Council of the Royal College of Surgeons had granted him the use of the house in Lincoln's Inn Fields until the following midsummer; and it was not until after the autumn holiday, which was spent in Scotland, that the Flowers occupied their new house at 26 Stanhope Gardens.

His official letter to the Council of the Royal College of Surgeons resigning his appointment as Conservator was read at a meeting on March I 3 , I 884. It was moved by Sir James Paget, seconded by $\mathrm{Mr}$. Erichsen, and resolved unanimously that

The Council hereby desire to express to Mr. William Henry Flower their deep regret at his resignation of the office of Conservator of the Museum of the College.

That they thank him for the admirable care, judgment, and zeal with which for twenty-two years he has fulfilled the various and responsible duties of that office. That they are glad to acknowledge that the great increase of the Museum during those 
years has been very largely due to his exertions, and to the influence which he has exercised, not only on all who have worked with him, but amongst all who have been desirous to promote the progress of anatomical science.

That they know that, whilst he has increased the value and usefulness of the Museum by enlarging it, by preserving it in perfect order, and by facilitating the study of its contents, he has also maintained the scientific repute of the College by the numerous works which have gained for him a distinguished place among the naturalists and biologists of the present time.

And that in thus placing on record their high appreciation of the services of Mr. Flower, the Council feel sure that they are expressing the opinion of all the Fellows and Members of the College, and that they will all unite with them in wishing him complete success and happiness in the important office to which he has been elected.

The new and greatly enlarged sphere opened to him by his acceptance of the Directorship of the Natural History Museum made an instant demand upon his thought and energy along so broad a front, that the difficulty of ever knowing where to begin might well have daunted him. By the change of title from Superintendent to Director, and by the enhancement of the salary to $£ \mathrm{I} 400$ a year, his position was made vastly stronger than was that of Owen. But he had to rely on his own good sense and tact, and upon the ability and willingness of the keepers of the various departments to recognise the merits of any measures proposed by him to ensure their fulfilment. He was fortunate both in his colleagues and in his own natural gifts.

Indeed, the description of an ideal librarian, that he "should possess the temper of a saint and the 
manners of an ambassador," was eminently true of Flower.

One of his most distinguished colleagues, Mr. G. A. Boulenger, F.R.S., says :-

His consideration for others and appreciation of their work and plans for work were almost superhuman. He gave all his time in the Museum to the furtherance of its daily activities. He was always accessible. Every one could walk in to see him, or could count upon having "next turn" if he were engaged; and though his purely administrative duties took up a great part of every day, with the correspondence, interviews, and receptions which it entailed, he found time to carry on a great and original series of expositions of natural laws and facts, all of which he planned and superintended, and some of which was the work of his own hands. ${ }^{1}$

The work by which, apart from his administrative success, he will be always known, was the arrangement of the cases which now stand in the Great

1 Lady Flower writes :- “ The British Museum had been of such paramount interest to my husband since he was a boy, that when actually appointed to this important post in it, he began his work with an enthusiasm that could not but affect others, and this enthusiasm was continued to the end. The advantage to him of his position as Chief seemed that he could work in the Museum longer than any one else. Often would he remain there after it was closed to the public, and after the staff and attendants had gone, in order to secure some uninterrupted hours for work, and then quietly let himself out with his master-key. In regard to zeal in performing routine work he quoted from an old book, "God is close to us in our daily life," and in the familiar homely places, the unremitting attention to simple and high sentiments in obscure duties - that is the maxim for us. I settled myself ever firmer in the creed that we should not postpone and refer and wish, but do broad justice where we are, accepting our actual companions and circumstances.' And in this spirit he worked, most anxious that all about him should have full justice. Few things distressed him more than disagreements; he always endeavoured to 'throw oil on the troubled waters,' and generally succeeded through the calmness of his own spirit. He knew nothing of professional jealousies, or what so often disturbs the minds of discoverers as to priority of discovery." 
Hall, the one feature in the building which survived from among the proposals of Owen. In it he, as we have said before, intended to place his "Index Museum." Flower at once determined to use it for a different purpose from that of the other parts of the building. But while so far accepting Owen's idea, he entirely changed the concept.

In his report to the Trustees, dated January I, I885, after referring to the progress made in the departments of Geology, Botany, and Mineralogy, in which the arrangement after the transfer from Bloomsbury was almost complete, and to the Zoological Department, the collections in which, being the last to be moved from Bloomsbury, were in a less forward state, Flower wrote :-

Of the Central Hall, which is more especially under the charge of the Director (himself), more must be said. In the original plan of the Museum it was designed for the purpose of exhibiting a collection of specimens ... which has been at various times styled an "index" collection and a "type" collection. Owing to the urgent requirements of other departments, little progress has been made in collecting and arranging specimens for this collection. A definite commencement has, however, now been made upon a systematic plan, the intention of which is to illustrate the leading points in the structure of each large group (such as those to which the term "class" is erroneously applied) by carefully selected and prepared specimens, accompanied by explanatory descriptions pointing out the typical form, with the most important deviations from it, and the terms by which these are known in current zoological literature.

The illustrations to such a series will be mostly of a different nature from those at present in the other parts of the Museum, as they will not merely be specimens but parts, the corresponding 
organs of different animals being brought into juxtaposition for comparison in a way which cannot be effected in the galleries, where the specimens are necessarily arranged in systematic zoological or botanical order.

In such a series the illustrations will naturally be derived equally from living and extinct forms.

With regard to botany it is obvious that such an introductory treatment will be equally applicable and instructive, as in zoology, and should be in sequence with it in any general exposition of the leading modifications of the organic world.

The Keeper of Mineralogy ${ }^{1}$ has already formed an admirably arranged collection introductory to the study of his departments, which, allowing for the great difference in the nature of the subjects, gives a good idea of what an introductory collection to the other departments may be. It is, however, arranged, not in the Central Hall, but in a part of the gallery devoted to minerals. The far superior illustrations of the specimens in their present position to that which they would occupy in the bays of the Central Hall, a matter which is of the utmost importance in the case of minerals, is a strong reason against any disturbance of the present arrangement.

Flower's idea was to illustrate natural laws and the facts of evolution on the lines which he had originated in Lincoln's Inn Fields, the adaptations of organs to function in all classes of animals, and to deal with every modification of form in logical series. He added to this later some striking examples of the leading facts of variation under domestication, protective coloration and form, and of the structural laws of plants.

Classification was also illustrated, and any striking

1 Mr. L. Fletcher, F.R.S. Visitors to the Museum will find this exquisitely illustrated concept of the underlying order in the mineral world developed and extended in the Mineralogical Gallery, where the beauty to be found in natural mineral products is also a most striking feature. 
if simple fact, if not generally known, was never omitted, as, for instance, by raising the feathers of the head to show that a bird has an external ear.

After the conception came the enormous practical difficulty of carrying it out, by obtaining the specimens, of selection, of continuity, and of setting the objects out in the best way, that the whole might be clear and unmistakable and tell its own story. This was his personal occupation for years. The results compel the admiration of every foreign zoologist who visits the Museum, and delight hundreds of thousands of his fellowcountrymen and country-women of all ages annually. They have been copied all over the world, and are still unequalled.

It should be mentioned that he himself designed the cases for the bays in the Great Hall. By I 886 he was able to report that the first bay, containing the series showing the osteology and dentition of the Mammalia, was practically complete. In the second bay the series showing the modifications of the outer covering, such as skin, hair, horns like those of the rhinoceros, nails, claws, and horny plates as in the armadillos, was also completed. It will be noticed that his promise to illustrate the characteristics of "classes" was faithfully observed. The two first bays gave the complete story of the inner and outer skeleton of the Class "Mammals," with their teeth, and showed also their order of classification. The next bay was devoted to the Class 
"Aves" or birds, the next to the Class "Fish," and the next to the Class "Reptiles."

By 1886 the cases showing the beaks, feathers, tails, and limbs of birds was nearly finished, and the bay devoted to fish was begun. On the opposite side of the hall a commencement was made of the exhibition of the morphological characters of the great groups of the vegetable kingdom.

In 1887 it was noted that the collections of zoology had increased in four years by 270,000 specimens. In that year the splendid collection of the metamorphosis of the British Lepidoptera formed by Lord Walsingham was presented by him to the Museum. The series introductory to the Mammalia in the Great Hall was increased by a complete set of the antlers of a stag, showing the horns which it had shed every year of its life; it was presented by Mr. W. H. St. Quintin. In the Bird series the anatomy of birds and the leading characteristics of the Class "Aves" were begun. In their completed form they occupy one bay of the hall, and are perhaps as good an example as could be found of Flower's "selective" methods of graphic exhibition. The problem was to give a connected idea of the general meaning of the word "bird," and of the kinds of birds and the organs of birds, so that a person, even coming from another planet, might learn as much about them as possible in a small space and in a short time.

At the back of the bay, and in the centre, is a 
large label-"Aves." Below this are three of the most typical yet most dissimilar birds. An enormous albatross, typical of flight, spreads its wings from side to side of the bay. An apteryx, flightless, and adapted only for running on the ground, stands on one side ; and a penguin, adapted only for swimming with legs and wings-mainly living in the waterillustrates the other extreme. In a case on the left are the skeletons and parts of skeletons of the typical birds; also the eggs of birds, and a complete series of the development of a number of chicks, all of one hatch, at different ages. Heads, beaks, feathers, down, wings, ears occupy another case, the series of feathers and feather structure being of exquisite beauty. In another case are the organs, nerves, muscles, and the modifications of feet for seizing, swimming, scratching, perching, or climbing.

The introductory collection to the "fish" was carried forward and that to the "insects" begun in this year, and a start was made with the striking cases in the central part of the hall illustrating general laws, such as protective mimicry, variation under domestication, and conformity to environment.

The case in which are the hybrids between the carrion crow and hooded crow and those showing gradation between two different forms of goldfinch were formed in this year, as were those showing what selective breeding has done in producing many marked breeds of pigeons from the common "blue rock." 
The rapid progress and vitality of the Museum began to attract the gifts of collectors on a great scale, while the excellent understanding between the Director and the keepers of different departments, and the personal share taken by the former in the elaboration of the Central Hall, convinced every one interested in zoology that the national collection was in competent hands, and encouraged donations. In the single year referred to, Lord Walsingham, besides his collection of mounted larvæ, pupæ, and perfect examples of British Lepidoptera, presented the whole of his collection of Macro-Lepidoptera made during his travels in California and Oregon in I87I and 1872 ; Messrs. Godman and Salvin presented nearly 4000 specimens of American birds; and Mr. Wardlaw Ramsay deposited, under certain conditions, the collection of bird skins, mainly formed by the Marquis of Tweeddale, Flower's predecessor as President of the Zoological Society, consisting of some 40,000 bird skins, and particularly rich in the birds of the Philippines, Andaman Islands, and Malay Peninsula, in which the collections of the Museum were deficient. As an example of the different personalities interested, it may be noted that donations came from Emin Pasha, then in Central Africa, and from Mr. Ruskin, who presented to the Mineralogical Department the Colenso Diamond and the Edwardes Ruby. Ruskin was keenly interested in the work done in the Mineralogical Department, 
where a case of all the various beautiful modifications of silica or "flint," from a rough flint stone from the road-side to the most exquisite agates, arranged by him, is still to be seen.

In r 888 Flower completed the case illustrating albinism in the Great Hall, and began that showing the phenomena of melanism; and Mr. F. G. Godman presented to the Museum a collection of 11,000 North American birds, all carefully named by leading American ornithologists. In 1889 the case illustrating melanism was completed, and the bay containing the introductory collection to the class "Reptiles" was filled and fully labelled.

In 1890 the set of cases exemplifying general laws was increased by that illustrating variation in a single species according to age, sex, and season in the ruff, the males losing the ruff and becoming like the females in winter plumage, though they differ in size. In the lower part of the case the birds are shown in breeding plumage, when the females gain richer colours, and the males assume the "ruff" from which the birds are named. They also differ in plumage so much that of the twenty-three birds shown no two are alike. In the same year the Booth collection of British birds, stuffed and mounted in the most realistic and natural surroundings, was offered to the Museum. It so happened that the beautiful series of birds and their nests, originated and arranged on a similar principle by the learned Keeper of Zoology, Dr. Günther, F.R.S., for so 
many years a principal figure at the Museum, was then rapidly increasing in numbers at South Kensington, and it was decided that Mr. Booth's birds should remain at Brighton. Flower went down and opened the institution in the Dyke Road, which is now among the greatest attractions of "London by the Sea."

Continuing his graphic method in the Great Hall, the case of animals which undergo the change to white in Arctic climates as a form of protection was set up in $189 \mathrm{I}$. In the same year a collection of 24,000 birds' eggs was catalogued and arranged by Mr. Seebohm. Next in order of time to the arrangement of the Arctic animals in the hall followed the well-known case showing the skeletons of man and horse standing side by side, with all the corresponding bones labelled and shown. Flower hoped that among other things this case might be useful to artists who painted horses or their riders.

In 1895 the large case numbered I I, showing the orders and sub-orders of mammals, the prevailing types and their geographical distribution, was begun and carried forward, and the examples of protective mimicry among insects, which have delighted and astonished tens of thousands of visitors since, were begun. These examples, selected from the most striking, beautiful, and almost miraculous instances found by recent discoverers, made perhaps more impression on the ordinary intelligent public than anything yet shown in the Museum, and still 
year by year these examples grow, though the marvel remains a marvel still. The final results are obvious. But how the adaptation came about is still a mystery, nor is there one single example of mimicry on the way to completion. Each species and each instance might have been metamorphosed in an instant of time for anything that has been discovered to the contrary.

In another department, botany, then under the charge of Mr. Carruthers, F.R.S., now under Mr. George Murray, there was secured for the Museum what may be termed the ultimate perfection of vegetable growth, so far as age and size condition perfection - the section of the gigantic Sequoia, one of a group of trees of such vast age that certain trees might well have been flourishing and shedding their seeds before the birth of Christ. The case showing the conformity of desert animals to their surroundings was completed later, and another showing the different types of molluscs.

In I 895 , on the retirement of Dr. Günther under the age regulations, Flower took over the whole duties of Keeper of Zoology, without payment. He at once began the work, from which many a younger man might have shrunk, of the complete rearrangement, classification, and labelling of both the birds and mammals. In addition each group was assigned to its particular habitat by an ingenious use of small maps, in which the range of the animal on the earth was shown in scarlet paint on a white outline map. 
The type characters of each order and family were also carefully explained in print and illustrated by specimens. These two great undertakings, going on side by side, and added to all his administrative and social duties, taxed his brain and health severely, in spite of the unfailing assistance which he received from the Museum staff, and more especially from Dr. Bowdler Sharpe and Mr. W. Ogilvie Grant in the complete reorganisation and classification of the birds, and by Mr. G. A. Boulenger, Mr. Oldfield Thomas, Dr. Woodward, Mr. Jeffrey Bell, and indeed by all those on the staff in other departments. Volunteer help was also forthcoming. It was stated in the Report of I 896 that 33,000 more persons had visited the Museum than in the previous year.

A provisional whale room to accommodate the collection of Cetacea, which Flower had always deemed could only be properly housed in the national collection, was built. An example of the importance of detail in museum exhibition occurs in a change made in the next year, 1897 , which involved an alteration in the mounting of all the specimens of birds and of many others. Hitherto these had been placed on stands of pale polished sycamore. Flower thought that these were ineffective, unnatural, and ugly, and consulted the President of the Royal Academy, Sir Frederick Leighton, as to what improvements could be made. In accordance with his suggestion the stands were 
made of dull wood stained a dark brown. A change of this kind, though apparently trifling, effects an improvement in the appearance of whole departments. It is also costly, and involved an enormous amount of work. The opportunity of withdrawing badly-stuffed specimens and of mounting others on natural wood with the bark on was not neglected.

A great change was also begun, on logical lines, in the Mammalian galleries. Hitherto the stuffed skins had been placed in one gallery and the skeletons in another. They were now placed side by side in the same galleries.

In I 897 great progress had been made with the reorganisation of the birds. The great gallery on the ground floor, to the left of the main entrance, was well on its way towards completion, and all the specimens placed in systematic order, beginning with the bower birds on the left, and ending with the ostriches on the right; while down the middle and in some of the bays were cases illustrating the nesting habits of British birds. In every one of these the surroundings are either exactly those of nature, or the most careful artificial imitations-the same rocks, sticks, flowers, grasses, reeds, or heather.

In 1898 the rearrangements of the mammals on Flower's system was nearly completed for the classes Chiroptera (bats), Edentata, and Primates. Money was also forthcoming for good stuffing, such as Flower had long been anxious to get.

This year saw the addition of Sir Richard 
Owen's statue to the Central Hall, when Flower took occasion to refer in eulogistic terms to some new lights rather favouring Owen's contention in the almost forgotten controversy about the brains of men and apes.

As the Director had never ceased to be solicitous that the public in general should have every chance of seeing the collections, the question of Sunday opening was one which he often brought before those responsible for the Museum.

In 1885 a motion was carried in the House of Lords that the Museum should be open on Sunday, but this view failed to commend itself to the House of Commons at the time.

In 1889 an offer of $\measuredangle 500$ towards the expenses of Sunday opening was made by the National Sunday League. At a general meeting of the Trustees in February 1890 it was resolved that the Trustees "hesitate under present circumstances to take the responsibility of opening the Museum on Sunday without the concurrence of the Government."

But in 1896 the House of Commons passed a resolution that the Museum should be opened on Sundays, and the doors were opened for the first time on Sunday afternoon, May i7, I896. Thus the privilege which Flower had always been anxious to give his busy friends of going round the Museum on the day of rest was now extended to every one in the country. Archbishop Benson, then the principal 
Trustee, always steadily supported this extension, as did the Dean of Windsor, Randall Davidson, now Archbishop of Canterbury. The change was greatly furthered by the entirely voluntary services of the staff, who took it in turn to be on duty. 


\section{CHAPTER XI}

THE NATURAL HISTORY MUSEUM-continued

Probably Flower found a certain degree of relaxation in planning and sometimes in executing the work in the Central Hall. His sense of beauty and his correct taste lent to the exposition of the individual objects as well as to the series both character and refinement. Occasionally he would reserve some particularly choice portion for his own hand. The writer once visited him on a morning in which he had found leisure to indulge in this form of pleasure. He thought that the series from the plumage of the peacock illustrating Darwin's chapter on the development and gradation of ornament needed renewal, and was undertaking the work himself, with the accurate knowledge of the markings and position of every feather on the peacock's back and train which a fly-tyer has of the place of the few special feathers in a bird's skin which he may need for his flies. He had taken a fine skin of a wild jungle peacock in order to have the very best plumage, and with his steel tweezers had taken out each pair of feathers, as suited the 
illustration, and was laying them side by side in two rows on a mahogany board, trying or rejecting different "links" to see which fitted best. "I think that a feather is almost the most beautiful thing in the world," he said, "and these are almost the most beautiful feathers." $\mathrm{He}$ would try the effect of position half a dozen times over when placing a specimen on the walls, thinking no detail insignificant. There is a fine tiger's head and claws, illustrating, or rather as a comment on, the teeth and claw series, in one of the alcoves. Sir William tried the paws in various positions and altered the length of the portion of forearm attached more than once before he was satisfied. His personality made friends, not only for himself, but for the national work which he was carrying out, among all classes, from the Trustees and Ministers who controlled the Museum or the funds which enhanced its efficiency to the travellers, explorers, or collectors who could aid in its enrichment. Among his friends was Captain David Gray of Peterhead, one of the most successful captains of whaling expeditions of the day. He was known as the "King of the Whalers," and was one of the last of the successful British whaling captains. Gray was greatly interested in the natural history of the whale generally, and much pleased that a naturalist and anatomist of Sir William's eminence should have devoted so much time to the subject. He deplored that there was 
not a specimen of a right whale in the Museum, and promised that if he could he would get one for Sir William. It so happened that on his very next voyage Gray's ship had the good-fortune to harpoon and capture the very largest right whale which he had ever seen. The "fish" was fastened to the vessel by chains, the blubber stripped off, and everything was in train for taking off the flesh underneath and securing the skeleton, when another whale was seen to blow. The crew, who had a right to a share in the profits and were not enthusiastic naturalists, insisted on dropping the flensed body of the whale and going after the fresh one, and Captain Gray, with the greatest chagrin, saw the unique specimen sink to the bottom of the Arctic Ocean. When he came back he was urgent that Flower should ask for a sum from the Treasury to buy a really good whale. "Why," he said, "you have just paid $£ 70,000$ for a Raphael! I can tell you that a right whale, just killed, and with all the whalebone in his mouth, is a finer picture than Raphael ever painted." When in I 895 Sir William himself became "Keeper" of Zoology, one of his first new departures was to cause to be executed in papier mache, according to a plan which he had long entertained, a complete series of life-size models of the Cetacea, but in which the skeleton is retained, while the body is represented in half-section in a composition exactly resembling the flesh and skin, showing the animals in a section cut horizontally, 
so that from the side a correct idea of their form and dimensions could be obtained without unduly crowding the gallery in which they were placed.

Six months after his appointment as Director, Flower assisted at the ceremony of installing the fine statue of Charles Darwin, by Sir Edgar Boehm, on the grand staircase, from which his pondering face now looks down on the Great Hall, in which Flower was later to give the most graphic exposition of his interpretation of the laws of living nature.

Flower as Director, with the executive committee, received the Prince of Wales and the other distinguished visitors at the entrance. The Prince and the President of the Royal Society stood on either side of the statue, which Professor Huxley then unveiled, and as chairman of the committee formally presented it to the Trustees. ${ }^{1}$ In his speech, though holding that Darwin no more needed a statue to perpetuate his memory than did Copernicus or Harvey, he affirmed that its presence would remind every student who entered the doors opposite of an idea according to which they might shape their lives, if they wished to use the opportunities offered by the Museum to the best account.

During the earlier years of his Directorship Flower was steadily engaged in four principal lines of activity, to which must be added the calls made upon his time as President of the Zoological

1 The Archbishop of Canterbury, Dr. Benson, as principal Trustee, receiving it. 
Society. He was administering the Museum generally and developing his synoptic series in the Great Hall. He was steadily forwarding the interests of the Zoological Society and stimulating interest in the Anthropological Society and its work. A Fellow of the former Society says: "Sir William Flower made an ideal President. His stately presence, tall figure, and fine head seemed naturally to fit him for the great carved oak presidential chair, whence he really 'presided' over the meetings-whether the afternoon meetings of the council or the fuller evening meetings of the Society generally. He listened attentively to all the papers read (as proved by his after-remarks on them), even when, as occasionally must be the case in any scientific society, they were dull or involved. Also he was quick to observe if the audience were getting bored, when he would suggest to the reader to omit some of the lists of names and numbers or unnecessary details, still with such courtesy and gentleness that even the author could not feel hurt; whilst in the general discussions that followed Flower not only guided them to the most important parts of the papers, and called upon those Fellows most qualified to speak on the various subjects, but also showed the greatest tact, as well as common sense and decision, in suppressing any ill-feeling or personalities, which sometimes arise in the heat of discussion." He was also popularising the Museum and interest in zoology on the part of all classes; 
and lastly, he was pursuing with an energy which is very remarkable, considering all the various calls on his time and thought, his own researches into the history and structure of certain animals, notably the horse and the whale. The writer of the obituary notice, published in the year-book of the Royal Society (No. 5, I90I), says: "While maintaining the high scientific reputation of the National Museum, he continued to popularise the institution and science by taking parties of working men round the Museum on Saturdays, and occasionally a distinguished visitor like Dr. Nansen or Professor Virchoff would join the group. Also on Sundays he would take a few busy men, whose occupations prevented their being able to come on week-days, himself unlocking the doors, so that no 'Sunday labour' was involved. In this way nearly all the Judges were enabled to see the Museum quietly on a Sunday afternoon, the venerable Lord Hannen specially saying what delightful 'refreshment' it gave him after a hard week in the Law Courts! Many ambassadors and foreign ministers, also artists, members of Parliament, and distinguished officers of the Army and Navy, were glad to avail themselves of this privilege, Flower himself explaining the Museum and showing the latest additions; and afterwards they would come on to tea with Lady Flower in Stanhope Gardens. He received many members of the Royal Family, who honoured the Museum with their presence, 
in this quiet manner; also statesmen, as the Right Hon. W. H. Smith, Mr. Joseph Chamberlain, W. E. Gladstone, Mr. Hugh Childers, Mr. Anthony Mundella, Lord George Hamilton, Lord Northbrooke, Lord Kimberley, Lord Northcote, Lord Stanhope, his lamented brother the Rt. Hon. Edward Stanhope, Admiral Prince Victor of Hohenlohe, and many others."

Among Sir William's publications in the years from 1883 to 1885 were his notes on the Evolution of the Cetacea in 1883 , notes on the Nerves of Two Genera of the Delphinidæ in 1884 , notes on the Teeth of a Young Capybara in 1884 , Observations on the Osteology of the Natives of the Andaman Islands in 1884, and notes on Skulls of the Bottlenosed Whale, an essay on the Size of Teeth as a Character of Race, on the Classification of the Varieties of the Human Species, a list of the Cetacea in the Zoological Department of the British Museum, and a most interesting lecture, given at the Royal Institution, on the Wings of Birds.

In May I885 Flower was elected a Trustee of the Hunterian Museum. It will be remembered that he was also President of the Zoological Society. His administrative work at the Museum was also in this period not only a source of daily care, but was weighted with the responsibility of his very considerable schemes for the development of the Great Hall. Yet to these duties he added a very large amount of other and exacting public and scientific 
work. In June 1885 he distributed prizes in Birmingham Town Hall to the school children for kindness to animals. In October he lectured on "Varieties of Man" in the Free Library at Bethnal Green, and in November at Wellington College to the boys on "Birds which cannot fly." His second boy, now Captain Stanley Flower, Director of the Zoological Gardens at Gezireh, was at school there, and his youngest, Victor, was at a preparatory school near, and able to meet his father and mother at the station, while both were in the audience with their mother. The Wellington boys greatly approved of the lecture, and were good enough to extend their complimentary cheers not only to Flower, but to those of his family in the audience. By a curious prophecy, Dr. Wickham, the then headmaster, said half in joke that the elder boy, who had already won the Pender Prize for the best essay on Natural History, would perhaps succeed his father. As head of the Egyptian Zoological Gardens and Director of the Wild Animal Department of the Soudan, he in a measure fulfilled this prediction.

In the winter of 1885 Flower lectured at the London Institution on "Horses of the Past and Present." The history of the horse was one of the Mammalia of which he made a special study, and in which, by his lectures and writings, he steadily interested the public. He traced the descent of the modern horse, which he held to be the most 
interesting branch of the whole family. It had been continually changing while its relations stood still. It had increased in bulk, and in the length of its neck, until it was difficult to find anything now more perfect than its organisation. It had grown in size, for there were extinct relations no bigger than a hare. Its neck had grown longer, it had dropped its toes, lengthened its legs, changed its teeth, and from being one of a group of marsh-living slow animals had become the best adapted of all creatures for swiftness and for living on hard ground and on hard fare.

In the following year he gave a similar lecture at the same place on "Cattle, Past and Present," and at the Royal Institution another on the "Wings of Birds." In June 1886 he lectured at the Zoological Gardens on the "Pigs and their Allies"; and in the autumn at Onslow College on "Fins, Wings, and Hands," a lecture which, further elaborated, he delivered in the June following at the London Institution. His autumn holiday was spent partly in Switzerland with his wife and daughters Vera and Geraldine, and partly in a visit to Lord and Lady Wharncliffe at Wortley. In 1887 the first General Guide to the Natural History Museum was issued. Special guides in the departments of zoology, mineralogy, and geology had been obtainable before. But this, though marked "under revision," was practically the foundation of the present General Guide, in which the account of the 
history of the New Museum, of the building, and of the general scheme is contained. But the chief interest of the first General Guide was the progress which it marks in the expression of Flower's plans for the Great Hall. The "Index Museum" was rapidly becoming an "introductory series." Although Flower had only been Director for three years, the details of the scheme were steadily being filled in, and the London public was beginning to look forward with increasing pleasure to the next stage of growth in the cases.

In the same year we find him lecturing at Sion College on the structure of whales in reference to the doctrine of evolution, opening the Chelsea Industrial Exhibition, lecturing to the Essex Field Club, to the Kensington Clergy Club, and to the Middlesborough Natural History Society.

This was part of his general policy of widening the area of interest in Natural History among all classes.

The year i 887 was the Jubilee of Queen Victoria. On June 16 he acted as host, in his position as President of the Zoological Society, to the guests of the Fellows at a Jubilee garden party held in the Gardens. The invitations were issued by the President and Council, and between 1500 and 2000 guests were present. The Gardens were looking their best ; there was a large and beautifullydecorated marquee for the reception of the visitors and for the formal meeting of the Fellows, which 
formed part of the function, and the lawns were like a glimpse of Goodwood or Ascot. After the formal part of the meeting was finished Flower thanked the young Maharajah of Kuch Bahar, who was present with his brother, for the gift of a fine Indian rhinoceros, and presented him with the silver medal of the Society as a mark of their appreciation of his thoughtfulness.

He then read a complete summary of the history of the Zoological Society from its foundation in 1828. This summary, which is published in the Essays on Museums, was based on a perusal of the complete set of the old annual reports. Any one who reads these through, as the present writer has had occasion to do, will find that nothing of note or interest is omitted in this by no means long address, which dealt with the foundation and growth of the Society, its early ideals and objects, its efforts at acclimatisation, its publications, and the story of the animals in the menagerie and their treatment. He concluded by saying, "We have a responsibility to our captive animals, brought from their native wilds to minister to our pleasure and instruction, beyond that of merely supplying them with food and shelter. The more their comfort can be studied, the roomier their place of captivity, the more they are surrounded by conditions reproducing those of their native haunts, the happier they will be, and the more enjoyment and instruction we shall obtain when looking at them." 
The era of zoological parks, such as the 250 acres included in the new gardens at New York, had not yet then begun. But the present tendency of menagerie management is entirely in the direction recommended.

On June 2 I Flower received a letter from Lord Salisbury stating that he had "great pleasure in informing him that Her Majesty has been pleased on this occasion to confer on him the honour of Companion of the Bath in recognition of his distinguished services to science." On the news of this Huxley wrote :-

My DEAR Flower-I am very glad to see the C.B. in the Times this morning. There should have been a $\mathrm{K}$ before it, but the $\mathrm{K}$ is to Kome.

With our united kind regards and congratulations to Mrs. Flower and yourself, ever yours very truly,

T. H. HuXley.

In this year he was elected an Honorary Member of the Academy of Science of New York, of the Zoological Society of Amsterdam, and of the Imperial Society of the Naturalists of Moscow.

His chief public function was the opening, on June 30,1888 , of what has recently proved to be one of the most useful institutions of its kind in the country, the Marine Biological Laboratory at Plymouth. The uses to which such an institution could be put, both for science and business, were clear from the success of the fine Marine Laboratory of the kind presided over by Dr. Dohrn at Naples. 
To establish one in this country had long been an object with Professor Huxley and other biologists. Professor Edwin Ray Lankester, who had acted as Honorary Secretary of the Marine Biological Association of which Huxley was President, had displayed the greatest energy in recommending the project to public notice, as well as in commending it to scientific men.

When we consider that before it was in working order Parliament was asked to stop certain modes of fishing alleged to destroy spawn by dragging nets on the bottom, and that the staff of the Marine Biological Laboratory has since proved that the spawn of every food fish but the herring floats on the top of the sea, "the difficulty of approaching practical men" and asking for support may seem rather strange; but the difficulty was found in 1888 . On the other hand, the leaders of science worked hard; the Fishmongers Company gave $£ 2000$ and acted as hosts at the opening at Plymouth; Government guaranteed $£ 500$ for five years; and the Institution, though with a small income, started fairly. If it now needed further justification, it might be found in the fact that the Government have just established another on the east coast, dealing primarily with the food fishes of the North Sea. Huxley was too unwell to preside, and in his absence Flower took his place, and as VicePresident of the Marine Biological Association delivered the opening address. After pointing out 
that Professor Huxley was the pioneer in urging support for the study of marine life, and regretting the illness which caused his absence, he referred to the enormous importance of the subject both to science and economics in a country which has 2000 miles of coast, measuring the actual contact of land and sea in its various windings and bays. $\mathrm{He}$ explained the objects of the Laboratory, and described in some detail what had been done elsewhere, closing with an earnest hope that the expectations entertained of its future usefulness would not be disappointed. ${ }^{1}$

This hope has been more than realised. At the time of writing, the new North Sea Marine Laboratory, working in conjunction with experts in Holland, has already made quite unexpected discoveries as to the life and migrations of plaice and other food fishes in the North Sea, and is engaged in a form of "fiscal inquiry" devoid of controversy and full of promise. The publications of the Marine Biological Association at Plymouth have steadily increased in interest and value; and the movement, which had and has among its chief supporters Professor E. Ray Lankester, who was Honorary Secretary to the Association in its early stages, has more than justified the support given to it.

1 One of his last public functions was to open the Marine Laboratory at St. Andrews, presided over by his friend Professor William M'Intosh, F.R.S. 


\section{CHAPTER XII}

STUDIES OF WHALES AND WHALE FISHERIES

Among the most interesting of Flower's writings are a long series of original papers, essays, and notes on the numerous Cetacea of the world, both living and extinct. His study of the largest but least-known animals in the world began, very early, and he never missed an opportunity, whether at home or abroad, of seeing their bodies, skeletons, or, if possible, the living animal. Lady Flower says that he was always so delighted when he heard of a fresh specimen, that on his coming into the room one day looking particularly pleased she said, "You must have heard of another whale!" He had.

While he was at the Museum of the Royal College of Surgeons he worked for the medical profession and for the general public. But he would have been more than human had he not had private leanings in a particular zoological direction. His old friend, Mr. J. W. Clark, Registrary of the University of Cambridge, says, "What first induced him to take up the study of the Cetacea need not be investigated at this distance of time. Possibly he adopted the pursuit I66 
by inheritance from the founder of the Museum, John Hunter, who had written on the subject, and enriched his collections with such specimens as he was able at that day to collect ; possibly from a feeling that the subject had been neglected and needed thorough investigation; possibly also from the accidental circumstance that a correspondent, Mr. W. L. Crowther, of Hobart Town, Tasmania, presented in successive years a series of rare skeletons to the Museum. Whatever cause may have suggested the study, Flower made it completely his own, as the long series of papers contributed by him to the Proceedings and Transactions of the Zoological Society amply testifies. ${ }^{1}$ Of these, that on the Osteology of the Sperm Whale, which he was enabled to write through the liberality of $\mathrm{Mr}$. Crowther in sending a skeleton to the College of Surgeons, is undoubtedly among the most important, having regard to the abnormal characteristics of the animal; but future zoologists will thank him for those in which he describes new or little-known animals, as well as those in which he introduces a more intelligent classification, sweeping away, as he proceeds, a large number of hastily-determined species. The skeleton of the sperm whale arrived from Tasmania in 1865 , but it could not be exhibited in the Museum until 1868. This important acquisition, however, was only the first of a series. In 1866 a skeleton of the Greenland right whale

1 See the complete list in Appendix III. 
arrived from Greenland; in 1867 a complete narwhal skeleton; in 1868 the hitherto unknown Chinese dolphin ( $D$. sinensis); in 1872 a specimen of Berardius, an extremely rare whale from New Zealand, belonging to the family of the Ziphioids; and in 1874 a dolphin of the Ganges."

Opportunities for original study were naturally intermittent for any one who could not devote some years to whaling voyages. But Flower never lost a chance of seeing for himself the bodies or skeletons of the various Cetacea, whether stranded on the coast or in foreign museums. The results were seen in their most complete form in his essays on Whales and Whale Fisheries, originally given in the form of a lecture delivered at the Royal Colonial Institution in 1895, and reprinted with his Essays on Museums. In it he gave a full account not only of the wonderful structure of the various whales and of their habits as they roam the ocean or keep to the ice-fringe, according to their species, but also traced the scene of the whale fishery from its ancient field in the Bay of Biscay gradually northward as the whales were killed off and new grounds had to be found.

Before referring further to these chapters we may perhaps, with the advantage of looking back through Flower's skeleton diaries, which he kept without a break from 1853 till his death in 1899 , follow his own "whaling excursions" and see how exact knowledge on such a difficult subject may be quietly 
accumulated by taking opportunities as they occur, until the person interested finds that he, almost unconsciously, knows more of the matter than any one else. His first hunting ground was Rosherville. "To Rosherville Gardens with Dr. Murie to see the skeleton of the whale" is the entry under date November 14, 1863. In the next year a whale was reported to have been stranded on the Norfolk coast, and Flower went to see and measure it. He took with him Mr. James Flower, Articulator at the Hunterian Museum, and visited Norwich, where, in regular East Anglian fashion, they drove by dogcart to Cromer, as no railway then existed there. They looked up the gamekeeper at North Repps, and arranged operations for the next day. It appeared that the whale had been stranded some time before and buried in the sand. All the next day was spent in digging up the skeleton, which proved to be that of a lesser fin whale, 25 feet long. It had been cast ashore in November 1862, and buried by order of Mr. Gurney, as sand was a good preservative and kept the bones all together.

Flower caused the whole skeleton to be recovered, packed it up, and sent it to the Royal College of Surgeons, where it now is. Many years later, when he was advocating a different form of burial than in closed coffins, he referred to his experience in digging up the whale. In 1875 he wrote to the Times that as the public would not be likely to favour cremation, there was much to be said for 
Mr. Seymour Hayden's proposal that the bodies of the dead should be committed to the earth in wicker coffins.

"I need not shock your readers (he wrote in the Times) by attempting to describe the condition of bodies which have lain for years in a more or less perfectly closed coffin, but on the other hand I can affirm from considerable experience that such is the disinfecting power of earth that the necessary changes in the dissolution of the human body occur under its influence in the least offensive and injurious manner. Decay in earth, in fact, is quite a different matter from decay in water or air. Not many years ago it was my duty to superintend digging up the body of a whale which had been buried for two years in a sandy soil on the Norfolk coast. So far from the process being, as I anticipated from my experience of much more recent whales' carcasses, very unpleasant, the bones were found nearly clean, and quite odourless."

Three years after that in which he visited North Repps he secured for the Hunterian Museum the skeleton of a right whale from Copenhagen. In the September following he visited the Museum at Leyden and Utrecht to measure whales' skeletons, and also went to Louvain "to retake" notes he had lost on the same subject. Later he communicated the results of these visits to the Zoological Society by reading a paper on the Skeletons of Whales in the Principal Museums of Holland and Belgium, with descriptions of two species apparently new to science.

In the following June he went to Burton Constable, on the Yorkshire coast, near Hull, where a 
sperm whale had been stranded some time before on the foreshore of Sir Clifford Constable's property.

Writing to his mother, June 15,1865 , he said :-

My Yorkshire expedition was very successful. I did all I wanted and the weather was magnificent, luckily for me, as the Burton Constable whale was in the open air, and a shower of rain would have greatly interfered with my proceedings. . . . It was very pleasant, sitting among the beautiful trees of the park, drawing and measuring the great whale's skeleton, with the birds singing all around, and the red deer looking on with much surprise, and the full moon rising up while the sun went down. There was a starling's nest with five young ones comfortably lodged in the whale's brain cavity.

In July 1875 a grampus was caught at Sidlesbarn, near Chichester, and taken alive to the Brighton Aquarium, where it lived only a few hours. Flower, "the most eminent living authority on the Cetacea," to quote a contemporary notice, examined and measured it, and also identified the species.

In 1877 a white whale was brought alive to the Westminster Aquarium, but it also died.

Referring to this loss, Frank Buckland paid a tribute to Flower's ungrudging willingness to teach all and sundry what he knew :-

I was aware (he wrote) that had the whale not died, Professor Flower would probably have consented to give a lecture to working people on the structure and movements of the whale, with the living illustration before him, as he sometimes explains to parties of working men the specimens in the Museum of the Royal College of Surgeons. To listen to our greatest authority 
on the whales and seals discoursing in his pleasant gentle style and clear language on subjects with which he is so completely conversant is an intellectual treat which the most erudite zoologist may well enjoy; and as I looked on the dead whale's body I could not but feel that the public as well as the proprietors had sustained a double loss.

In a comprehensive though necessarily condensed review of Sir William's work contributed to Nature, Professor E. Ray Lankester, his successor, says :-

After the deaths of P. J. van Beneden and Jervais he was only rivalled in his knowledge of whales by Sir William Turner of Edinburgh. It was a special satisfaction to him to have been able to complete the admirable exhibition of whales at the Natural History Museum before his retirement-an exhibition which is not only unequalled, but is not even attempted in Europe or America.

In two lectures given, the one at the Royal Institution in 1883 , and the other at the Royal Colonial Institution in 1895 , he summed up the results of his long and patient attention to this subject in a form which, though necessarily popular, is perhaps the most instructive material dealing with the structure and history of the whale and the story of the whale fisheries. ${ }^{1}$ That read at the Colonial Institute described not only the whale, but gave the history of the British and Colonial whale fisheries, ancient and modern, with the records of which he was very familiar. It is a curious story, then for the first time brought

1 They are reprinted in Flower's Essays on Museums (Macmillan). 
together. The earliest known regular whale fishery had for quarry a race of whales now absolutely destroyed, which were found at no great distance from our home waters. Its headquarters were in the Basque towns of France and Spain, Bayonne, Biarritz, Fuenterrabia, St. Sebastian, and many smaller ports. The prey were the Atlantic right whales, which then frequented the Bay of Biscay. First the Basques caught them by putting out in boats from the shore, and later, growing bolder, followed them in ships across the Atlantic to the Bermudas, Newfoundland, and Iceland.

Queen Elizabeth and all her court depended upon the Basque fishermen for the most prominent characteristics of their costume. The supply was, however, diminishing, when the attempt to discover the north - east route to China, about the close of the sixteenth century, led to the opening up of the sea between Greenland and Spitzbergen and the discovery of the Arctic right whale, an animal up to that time practically unknown to man. This being much more valuable, both on account of the larger quantity and finer quality of the whalebone it produced, and also the larger amount of its oil, for many years attracted the principal attention of the whaling ships of Europe. The English entered into the business at a very early period, but being unacquainted with the methods of catching whales, engaged Basque harpooners for all their early voyages, and closely followed their methods. The very word "harpoon" is said to be Basque. The Dutch also took the fishing up on a very extensive scale, and established a permanent settlement on the northern shore of Spitzbergen, which they named "Smeeremberg," and which was the rendezvous of the whaling fleet in summer, and to which the blubber was brought for boiling. In its most flourishing period the Dutch whale fishing employed as many as 260 ships and 14,000 men. When, however, whales 
became scarcer in the neighbourhood of the coast, and the ships had to seek them further in the open sea, it was found more economical to bring the blubber to Holland, and Smeeremberg was deserted.

The great war at the end of the last century, in which England kept possession of the North Sea, put an end to the whale fishery, not only of Holland, but of France and of all other countries which had engaged in it, and henceforth we maintained a monopoly of the trade. From the year 1732 to 1824 our Government paid bounties amounting altogether, it is calculated,

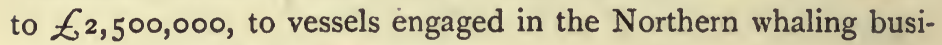
ness, to encourage the enterprise.

The ships at first sailed from London, then Hull, Yarmouth, and Whitby entered the field. In 1819 as many as sixty-five ships sailed from Hull. Since 1836 no ship has gone from London, and now Dundee and Peterhead are the only ports in the British Islands which keep up the Northern whale fishing, though on a much more limited scale then formerly.

The fishery between Greenland and Spitzbergen, which in the last century proved so productive, is almost played out, but that of Davis Straits and Lancaster Sound is still remunerative owing to the very high price that whalebone has lately been fetching. At the beginning of the century the average value was from $£ 70$ to $£ 80$ per ton, but a few years ago a sale was effected at the enormous sum of $£_{26} 65^{\circ}$ per ton; this is the highest price which has ever been given for it, and recently it has somewhat declined.

He showed that the trade which inspired the Cruise of the "Cachalot" was modern compared with the right whale fishery, although individual sperm whales approaching near the shore, especially in the neighbourhood of the right whale fisheries, had often fallen a prey to man. The systematic capture of this species began about the end of the seventeenth century from the Atlantic coasts of 
North America, especially of the part then called New England, at first only from the shore, but afterwards in sea-going vessels from New Bedford and other ports, which gradually extended their voyages into the Indian and Pacific Oceans.

From the year 1775 vessels engaged in the trade (assisted by Government bounties) regularly left the mouth of the Thames for the South Seas, making voyages of three or four years' duration; but since 1853 the business has been abandoned by the English, and what little remains of it has reverted almost entirely into the hands of the Americans. Sperm oil has fallen so greatly in price that its production is now hardly a remunerative undertaking, and it has found a rival in all the qualities which render it of special value in the oil of an allied but much smaller species, the bottlenose whale (Hyperodon), which has consequently become the object of a regular fishery in the North Sea, especially to the Norwegians.

The extraordinary fact of the absolute and complete destruction of at least two species of right whale by the reckless greed of the whalers was first made public by Flower, who may properly be regarded as almost the discoverer of the Basque whales as a separate species. Of these (the North Atlantic right whale) he says :-

It is a singular fact that the existence of the species was quite overlooked by naturalists until lately. All accounts of it which are to be found in the numerous records of European whale fishing 
have been attributed to the Greenland whale, which was supposed by Cuvier, for instance, to have had formerly a much wider distribution than now, and to have been driven by the persecution of man to its present circumpolar haunts. To the two Danish naturalists Eschricht and Reinhardt is due the credit of having proved its existence as a distinct species, from a careful comparison of numerous historical notices of its structure, distribution, and habits, and although they were at one time disposed to think that the species had become extinct, they were able to show that this was not the case, an actual specimen having been captured in the harbour of San Sebastian in January r 854, the skeleton of which Eschricht was fortunate enough to secure for the Copenhagen Museum. More recently, specimens have been captured on the Spanish coast, the Mediterranean, North America, and Norway. A skeleton has fortunately been secured for the British Museum, the exhibition of which is only delayed for want of a proper room in which it can be mounted. ${ }^{1}$ In the North Pacific a very similar, if not identical, whale is regularly hunted by the Japanese, who tow the carcasses ashore for the purpose of stripping the blubber and extracting the whalebone.

In the tropical seas right whales, according to Captain Waring's whale charts, are seldom if ever seen. But when the temperate waters of the Southern Ocean were explored, there the right whales were found in abundance, just as they were in those of the North Atlantic.

It is an astonishing and deplorable fact that every single individual of these southern right whales, so far as can be ascertained, has been destroyed. That this should be possible when they had the whole ocean to roam seems almost incredible.

1 It is now in the whale room. 
But it came about from the habits of the whales themselves. Shortly before the birth of the young whale the mother always goes to land, to some favourite spot by the shore, where the calf is born. The North Atlantic right whales came to the Bay of Biscay for the purpose, and that one of the few survivors should have entered the ancient haunt in the harbour of San Sebastian for this purpose so late as 1854 , after nine centuries of persecution, is evidence of the strength of this instinct. In the Southern Ocean also the whales came to certain spots, soon well known to the whalers, to give birth to their young. Among these places were the bays by the Cape of Good Hope (Vaalfisch Bay among them), and South Australia and New Zealand. As there was no close time for whales, and every cow and calf was killed, Sir William Flower noted that "the result has been to the southern right whale what it was to its Atlantic ally after its persecution by the Basques, although it was brought about in a much shorter time. To destroy it in its last remaining breeding-places was to destroy it everywhere. Although we have at present unfortunately very little accurate information about its breeding haunts, there is every reason to believe that the Antarctic right whales retire in the Antarctic winter nearer to the South Pole. Sir James Ross in 1840 , in lat. $64^{\circ}$ nearly due south of New Zealand, and again in 1842 , in nearly the same latitude south of the Falkland Islands, found 
right whales very abundant in the month of December. On the strength of this observation it has been thought that a whale corresponding to the Arctic right whale might be found in the Antarctic seas. Two years ago (1896) some ships sailed from Dundee in the hope of meeting it, but were completely disappointed. No trace of such whales were found; for doubtless Sir James Ross had only come across the winter haunts of the same which were then undergoing the process of ruthless extermination in their breeding-places on the Australian and New Zealand coasts."

Since then other expeditions to the Antarctic Ocean have ascertained that not a single one of these right whales survives. At the other Pole the whales, instead of coming ashore to breed, have their calves by the edge of the ice, under which they retreat when attacked, and have thus managed to survive.

Among the details of the story of the British whale fishery, Flower traced it all round our southern and eastern coasts by the remains of whales found often at the most insignificant seaside villages.

The great jaw-bones, which remained after the whalebone was taken out, were used as gate-posts, arches to garden walks, or parts of arbours. These still remain in such places as Leigh, and Gravesend, Yarmouth, Wells-next-the-Sea, Whitby, and other ports farther north. The present writer was once in the street of the little village of Cley, in Norfolk, 
near a famous alighting-place of migrant birds, when an ancient inhabitant drew attention to a curious row of posts, with chains fastened to them, in front of . one of the larger houses, which posts he declared were "all boon." They were sawed-up lengths of whales' jaw-bones. 


\section{CHAPTER XIII}

\section{ESSAYS ON MUSEUMS}

IN 1889 Flower was elected President of the Zoological Society for the eleventh successive year, a fact which he notes with satisfaction in his diary. His chief work outside the Museum in this year was his Presidential address at the meeting of the British Association at Newcastle on September 4. He took for his subject "Museum Organisation," following, as he reminded the audience, the advice of $\mathrm{Mr}$. Spottiswoode, one of his predecessors in the Presidential chair, that the holder of the office "would generally do better by giving utterance to what has already become part of his own thought than by gathering matter outside of its habitual range for a special occasion."

Flower said that museums from one or other point of view had "occupied his time and attention almost from the earliest period of his recollection," and proceeded to convince his hearers of this fact by a retrospect of Natural History Museums in the past, a theory of what they should be at present, 
and an opinion as to what they could or could not do to advance knowledge.

In the historical part of the address he stated that though the first "museum" was founded by Ptolemy Soter at Alexandria about the year 300 B.C., it was really an academy. The first Natural History Museum was the Temple at Carthage, where Hanno hung up the skins of the gorillas which he brought home from the West Coast of Africa. The earliest printed catalogue of a museum is that of Samuel Quellenberg, a physician of Amsterdam, published in 1568 in Munich; but in the same year Conrad Gesner published a catalogue of the collection of Johann Ventmann, a physician of Torgau, in Saxony, consisting of about 1600 objects, chiefly minerals, shells, and marine animals. Shortly afterwards the Emperor Rudolph II. began to accumulate the treasures which proved the beginning of the great Museum of Vienna. The first miscellaneous museum collection, largely of objects of Natural History, was made by the two John Tradescants, father and son. The son published in 1656 a catalogue of this "Collection of Rarities," preserved at South Lambeth, near London. The first division was devoted to "Some Kindes of Birds, their Egges, Beaks, Feathers, Claws, and Spurres." Among them were "Divers sorts of Egges, one given for a Dragon's Egge," "Easter Egges of the Patriarch of Jerusalem," "Two feathers of the Phœnix tayle," and "the 
Claw of the bird Rock, who, as authors report, is able to trusse an Elephant." Among "Whole birds" is the famous Dodo from the Isle of Mauritius ; "it is not able to flie, being so big." "This," said Flower, "is the identical specimen, the head and foot of which have passed through the Ashmolean collection into the University Museum of Oxford."

The formation of Natural History Museums was a "ruling passion" with several kings and queens of Sweden, which fact, probably quite unknown to most people, was of the greatest aid to Linnæus in his early studies.

The proper organisation of Natural History Museums was the main theme of the address, rather than of museums in general. Flower emphasised the need for their division into two departments-one for research, the other for the instruction of the public.

The first must be as complete as possible, with an immense number of specimens. In the second the numbers of specimens should be strictly limited. "The specimens kept for research, for the advancement of knowledge, for careful investigations in structure and development, or for showing the minute distinctions which must be studied in working out problems connected with variations of species according to age, sex, season, or locality, for fixing the limits of geographical distribution, or determining range in geological time, must not 
only be exceedingly numerous (so numerous, indeed, that it is almost impossible to put a limit to what may be required), but they must also be kept under such conditions as to admit of ready and close examination and comparison. . . .

"Collections of this kind must, in fact, be treated as books in a library, and be used only for consultation and reference by those who are able to read and appreciate their contents. To demand, as has been ignorantly done, that all the specimens belonging to our National Museums, for instance, should be displayed in cases in the public galleries, would be equivalent to asking that every book in a library, instead of being shut up and arranged on shelves for consultation when required, should have every page framed and glazed and hung on the walls. ... .

"In the arrangement of collections designed for research, the preservation of the objects from dust, light, and damp; their absolutely correct identification and record of every circumstance which can be known of their history ; their classification and storage in such a manner that each one can be found without difficulty or loss of time, and that they should be made to occupy as small a space as is compatible with their requirements, both on account of expense as well as of convenience of access, must all be principal aims. They should be kept in rooms provided with suitable tables, and a good light for their examination, and within reach of the 
necessary books of reference on the particular subjects which the specimens illustrate. Also the rooms should be so placed that the officers of the Museum, without too great hindrance to their own work, can be at hand for occasional assistance and supervision of the students."

Passing from the general to the particular, it may be remarked that at the Natural History Museum all these research collections are entirely in the hands and under the control of the keepers of the different departments, and of the eminent specialists who assist them. It has been noted previously that Flower, on the retirement of Dr. Günther, became Keeper of Zoology; he had then under his general control not only the whole of the divisions of this subject, such as entomology, ornithology, and the mammalia in the "research" collection, but also undertook the immense task of rearrangement of the general and exhibited collections in the galleries, according to his conception of how this should be done.

His general idea on the subject of the second part of a Natural History Museum, that devoted to instruction of the public, was that, unlike the research departments, "the number of the specimens must be strictly limited, according to the nature of the subject to be illustrated and the space available. None must be placed too high or too low for ready examination. There must be no crowding of specimens one behind the other, every one being 
perfectly and distinctly seen, with a clear space round it. Every specimen exhibited should be good of its kind, and all available skill and care should be spent upon its preservation, and on rendering it suitable for teaching the lesson it is intended to convey." Flower may very possibly have had in his mind at this time the exquisite specimens which adorn the public galleries of Mineralogy at the Museum.

The "instructional " arrangement of the minerals, which so impressed Flower by its symmetry and logical order that he referred to it as a type of what he wished done in the exposition of system in the organic world, is adorned by the very finest specimens which the Museum possesses, and many of them the most beautiful which have ever been found on the earth's surface or in the dark unfathomed caves beneath it. The finest emerald in the Museum, partly bedded in the rock in which it lay, the most resplendent masses of amethysts, of garnets, of rubellite or felspar, are matched and even eclipsed in beauty, and greatly surpassed in size, by other natural objects of such colour, shape, and variety as the imagination, not fed by facts, could never dream of, from the mines of the Andes, or of Alaska, the precipices of the Alps, the caverns of Cumberland, or the mountains of Styria. But once found, these beauties of the mineral world frequently need no human treatment. It is otherwise with the examples of birds, beasts, and fishes. 
The beautiful specimens of bird-stuffing seen in the series of British birds and their nests, begun under Dr. Albert Günther's auspices at the Natural History Museum, only drew attention to the failure to obtain anything like an approach either to the truth or the beauty of nature in the main galleries. It is this which Flower had in mind at Newcastle when he went on to say, "Here I cannot refrain from saying a word on the sadly neglected art of taxidermy, which continues to fill our museums with wretched and repulsive caricatures of mammals and birds, out of all natural proportions, shrunken here and bloated there, and in attitudes absolutely impossible for the creature to have assumed when alive. Happily there may be seen occasionally, especially where amateurs of artistic taste and good knowledge of natural history have devoted themselves to the subject, examples enough to show that an animal can be converted after death, by a proper application of taxidermy, into a real life-like representation of the original, perfect in form, proportions, and attitude, and almost if not quite as valuable for conveying information on these points as the living creature itself. The fact is, that taxidermy is an art resembling that of the painter, or rather of the sculptor. It requires natural genius as well as cultivation, and it can never be permanently improved until we have abandoned the present conventional low standard and low payments for 'bird-stuffing,' which are utterly inadequate to 
induce any man of capacity to devote himself to it as a profession." 1

In concluding his remarks on his own Museum, Flower drew attention to the illustration of the double treatment of the research and the public division of a subject in the Botanical Department of the Natural History Museum. The general public are not such frequent visitors to this as to other parts of the Museum. But any one who sees its arrangement, which was begun under Mr. Carruthers after the removal from Bloomsbury, and continued under Mr. George Murray, will agree with Flower that as an example of good museum arrangement it is a model of what can be achieved. The public can learn with the least possible trouble, while the specialist in every department finds his own subject fully illustrated and the specimens ready to his hand.

The conclusions quoted above represent the main body of Flower's general convictions as to the management of museums, of which he, according to Professor Virchow, was "the Prince of Directors." They are elaborated elsewhere, in every Zoological Museum in Europe and America, but the substance does not alter.

There remained the consideration not of matters but of men; of the kind of initiative and control

1 The bird-stuffing which made most impression on Flower, as directed by an amateur, was that in Mr. Booth's collection presented to Brighton. The lifelike taxidermy of Mr. Rowland Ward and of Mr. Pickhardt at the Museum might in justice to them be "signed" with the artists' names. 
needful to obtain success. Part of what Flower said in this address, in which he summed up so many of his convictions, was quoted by the Archbishop of Canterbury at the unveiling of the memorial bust $^{1}$ in the Great Hall of the Museum on July 25, 1903. The following extract gives not only the quotation but its context :-

What a museum really depends on for its success is not its building, not its cases, not even its specimens, but on its curator. He and his staff are the life and soul of the institution upon whom its whole value depends, and yet in many-I may say most - of our museums they are the last to be thought of. The care, the preservation, the naming of the specimens are often left to voluntary effort, often excellent for special collections and for a limited time, but never to be depended upon as a permanent arrangement; or a grievously under-salaried, and consequently under-educated, official is expected to keep in order, clean and dust, arrange, name and display collections varying in extent over almost every branch of human learning, from the contents of an ancient British barrow to the last-discovered bird of paradise from New Guinea. . . A museum is like a living organism. It requires continual and tender care. It must grow or it will perish; and the cost and labour required to maintain it in a state of vitality is not yet by any means realised or provided for either in our great national establishments or in our smaller local institutions.

In the course of his Directorship even the Treasury was so far impressed by the work done at the Museum that Flower's representations as to the under-payment of the staff there were not heard with deaf ears. He had the great satisfaction of knowing that his assistants' good work was so far

1 By Thomas Brock, R.A. 
encouraged that each and all of them received an increase of salary. He himself was the only exception, probably for the sole reason that he never made any personal request of that nature.

$\mathrm{He}$ entertained very strong feelings on the inadequacy of the pay accorded to scientific men. The fact of his being in easy circumstances himself instead of making him indifferent only increased his sympathy for those engaged in the same pursuits who were not, and who were so ill paid as to be unable to educate their children properly, or to maintain reasonable comfort at home. He wrote emphatically on this subject in Nature, and also took every opportunity of bringing the question before those in authority at the Museum. He also urged, and obtained from the Zoological Society, an increase of the stipend of their Secretary, pointing out that if a body of scientific men did not set the example of paying their servants properly, other bodies could not be expected to act more liberally.

His views on local museums, field-club museums, and school museums are particularly valuable as showing both their proper limitations and their great possible use. Now that what is termed "nature study" is happily very likely to become a permanent "side subject" of education in our schools, his remarks on the aid and encouragement given by making good and suitable collections for school field-clubs and museums are likely to be re-read with special interest. 


\section{CHAPTER XIV}

\section{ANTHROPOLOGY}

From the time when Flower was appointed Conservator of the Hunterian Museum he had always taken a keen interest in Anthropology-the natural history of man. As the primitive races were certain to die out, he held that it was our duty to posterity to accumulate all the facts about them within our reach. The English in particular owed this to the world, as we had "disestablished and disendowed" more savage tribes than any other nation. Without attempting more than a retrospect of his services to this branch of science, we may here bring together some of the leading facts in order of time.

His nightly labours in measuring the skulls in the collection at the Hunterian Museum have already been referred to by his eldest daughter, Mrs. Shann.

"In I 864, when he was appointed, the skeletons numbered only 28 and the skulls 242 . When he left the Hunterian Museum the collection of materials for studying the physical character of the races of men consisted of 89 skeletons and 
I 380 skulls, exclusive of the Davis collection. A great deficiency was thus supplied, and increased opportunities for the study of osteological variations in man was thus afforded, for he never let slip an opportunity of acquiring small private collections of specimens. The greatness of the task which he set himself is shown by the fact that his osteological catalogue contained a list of I 300 skulls, of each of which he had carefully verified the measurements" (Lancet).

It was also mainly due to him that the College of Surgeons was induced to buy the splendid craniological series collected and scientifically catalogued by Dr. Barnard Davis. In I 878 , when the British Association met at Dublin, with Professor Huxley in the chair of the Anthropological Department, Flower read a paper on the Methods and Results of Measurements of Crania. Professor Huxley introduced a personal element into the discussion following it, by saying that he was so much struck by Flower's remark, that if he could get his family to consent to the arrangement, he could have his skull for the collection, adding that it would be found to be a very good example of the cranium of the average peace-loving Englishman!

For many years Flower steadily advocated the interests of what he thought was a much-neglected science, endeavouring, when opportunity occurred, to explain its object and to popularise it in the best sense. 
In doing this he was clearly abreast of even specialist thought on this subject. The date of the standard works on Anthropology fall almost without exception within the period of Flower's active life. Dr. Tylor's Researches into the Early History of Mankind was published in 1865 , his Primitive Culture and Anthropology in $187 \mathrm{I}$ and $188 \mathrm{I}$. The volumes of Wartz's Anthropologie der Naturvolken appeared between 1859 and 1865 . The Zeitschrift fiir Ethnologie was produced in 1868 , and the Revue de IAnthropologie in I 869.

The Anthropological Society was founded in I 863 , but it was not until I 87 I that it amalgamated with an older body, the Ethnological Society, under the rather cumbrous title of the Anthropological Institute of Great Britain and Ireland. Flower complained twenty-three years later of the "singular want of interest taken by the outside world in its proceedings," and at the British Association Meeting at York in $188 \mathrm{I}$, and at Oxford in August I894, he defined the scope and aims of the science, and urged its study. At the York meeting, after deploring the death of Professor Rolleston, who had been keenly interested in the subject, he proceeded as President of the Department, which had first been instituted under the Presidency of Dr. Tylor at the meeting at Montreal in $187 \mathrm{I}$, to draw the attention of his audience to Dr. Tylor's Anthropology, the first work published in England under that title, and then proceeded to lay before 
the audience the interest and importance of the subject as he conceived it.

Taking Lord Beaconsfield's estimate of the value of "race" as a social factor, he urged that race problems could not be understood unless the history of man were better known from the study of true relationship.

It is to the want of appreciation of the importance "of natural descent from a common ancestry" that many of the inconsistencies and shortcomings of government are due, especially the great inconsistency between a favourite English theory and a too common English practice-the former being that all men are morally and intellectually alike; the latter being that all are inferior to himself in all respects, - both propositions being egregiously fallacious. The study of race is at a low ebb indeed when we hear the same contemptuous epithet of "nigger" applied indiscriminately abroad by Englishmen to the black of the west coast of Africa, the Kaffirs of Natal, the Lascars of Bombay, the Hindoos of Calcutta, the Aborigines of Australia, and even the Maoris of New Zealand.

This appeal was intended to introduce the natural answer, which was that there were no means in England for the study of the history of the races of mankind, though in Paris in the Musée d'Histoire Naturelle, man, as a zoological subject, had a fine gallery allotted to him, abounding in illustrated matter, besides which there was a vigorous Society of Anthropology.

$\mathrm{He}$ also mentioned the curious fact that in Paris there was also what was termed the "School" of Anthropology, supported partly by private subscrip- 
tions and partly by the Municipality of Paris and of the Departments of the Seine. The "school" had laboratories and a staff of professors, who lectured on the very various branches of study into which the science is divided, treating it not only from the biological and anatomical point of view, but also dealing with ethnology, manners, customs, prehistoric man, and sociology. To these laboratories all the persons of outlandish nationalities dying in the Paris hospitals are brought and dissected, that any physical peculiarities may be duly noted and recorded.

In order that travellers may make the best of such opportunities for obtaining human specimens as chance may throw in their way, they can go to the "school" and receive instructions how to preserve such examples so as to be scientifically useful.

The possibilities of a natural classification of the races of man seemed to Flower remote.

The difficulties in the way of applying zoological principles to the classification of men are vastly greater than in the case of most animals, the problem being one of much greater complexity. When groups of animals become so far differentiated from each other as to represent separate species, they remain isolated; they may break up into further subdivisions-in fact it is only by further subdivisions that a new species is formed. But it is of the very essence of species that they cannot recombine, and so give rise to new forms. With the varieties of man it is otherwise. They have never so far separated as to answer to the definition of species. All races are fertile one with another, though perhaps in different degrees. Hence new 
varieties have constantly been formed, not only by segmentation, as it were, of a portion of the old stocks, but also by various combinations of those already established. . . . Without entering into the difficult question of the method of man's first appearance upon the world, we must assume for it a vast antiquity, at all events as measured by our historical standard. Of this there is now ample proof. During the long period when he existed in a savage state - a time to which the dawn of historical time was as yesterday - he was influenced by the working of those natural laws which have produced the variations seen in other regions of organic nature. The first men may very probably have been all alike; but when spread over the face of the earth, and made subject to very diverse external conditions of climate, food competition with members of his own species or with wild animals, racial differences began slowly to be developed. . . . Geographical position must have been one of the main factors in determining the formation and permanence of races. Groups of men isolated from their fellows for long periods, such as those living on small islands, to which their ancestors may accidentally have drifted, would naturally, in course of time, develop a new set of features, of skull, of complexion, or of hair. A slight set in one direction in any of their characters would constantly tend to intensify itself, and so new races would be formed ; . . . the longer a race thus formed remained isolated, the more strongly impressed would its characteristics become.

After expressing a hope that the Trustees of the British Museum would see their way to provide accommodation for anthropological collections in their new Museum, he concluded by urging his hearers to support the Institute.

Thirteen years later, at Oxford, General Pitt Rivers presented to the University his splendid collection illustrating the arts and customs of primitive people. Only two years after the York meeting 
one "Readership" in Anthropology was established at Oxford, and Dr. Tylor's lectures there, and the course given by Mr. Henry Balfour at Cambridge, on the Arts of Mankind and their Evolution, and by Professor A. Thomson on Physical Anthropology, were attracting attention. The organisation of the Ashmolean Museum under Mr. Arthur Evans had some bearing upon branches of the subject, the Indian Institute was encouraging interest in the races of our Eastern Empire, and the study of Comparative Physiology was becoming to some extent linked up with it. At Cambridge an Ethnological and Ethnographical Museum was being formed in I 884, of which Baron Anatole von Hugel was the first curator. In I 894 Anthropology was part of the examination subject for those taking up anatomy in the second part of the Natural Science Tripos. In an address at the Oxford meeting of the British Association in that year, Flower referred to the above facts as examples of the progress being made, and also cited the attention paid to the subject in Scotch universities. He touched on the value of systematic teaching of the "science of measurement," or Anthropometry, as a possible aid to the inquiry as to the laws of growth, of heredity, of comparative capacity of individuals in a community, and of the effects of different kinds of education and occupation, worked out first by $M$. Que in Belgium, and by Mr. Francis Galton, Dr. Roberts, and others in this country. He claimed 
the method of identification perfected by Berthillon in France as a proof of the practical usefulness of work originally begun solely from love of science. By the Berthillon system exact measurements are taken between certain well-known and fixed points of the bony framework of the body which are known not to change under different conditions of life. To this means of identification, which the British Government adopted, there was added, in consequence of a report of a committee appointed in 1893 by $\mathrm{Mr}$. Asquith, the ingenious method of personal identification by finger-marks, first used in India by Sir William Herschel, but later elaborated in this country by Mr. Francis Galton, who at his sole cost, in I888, opened and carried on the Anthropometric Laboratory at South Kensington.

Flower's own views on a possible classification of the human species are set out in his Essays on Museums, in a chapter elaborated from an address given at the anniversary meeting of the Anthropological Institute, January 27,1885 . It may be found exemplified, so far as craniology can illustrate it, in the upper gallery of the British Museum.

Linnæus sketched out four primitive types of man, the European, Asiatic, African, and American. Blumenbach added a fifth, the Malay. Cuvier suppressed the last two and reduced them to three.

After a perfectly independent study of the subject, I cannot resist the conclusion, so often arrived at by various anthropologists, and so often abandoned for some complex system, that the primitive man, whoever he may have been, has in the 
CHAP.

course of ages divaricated into three extreme types, represented by the Caucasian of Europe, the Ethiopian of Africa, and the Mongolian of Asia, and that all individuals of the species can be arranged round these types, or somewhere in order between them.

The appeal which he made to travellers to acquire material for the study of the natural history of man carried far.

Among others to whom he imparted his enthusiasm at a distance was Emin Pasha. Emin was by instinct a naturalist and collector. Before the fall of Khartoum he was in command of the Wadelai province in Central Africa, with practically a free hand to indulge these tastes as well as to govern and collect revenue. Like Sir Harry Johnston in Uganda, he also found himself in a peculiarly favourable position for studying the primitive races of Central Africa, and especially the branch of the pigmy tribes called the Akkas. He had met these pigmies living, and retained one as a servant. $\mathrm{He}$ also watched the spots where they buried their dead, and obtained two skeletons. In September 1887, after the fall of Khartoum, English public opinion was greatly agitated as to the fate of Emin Pasha and his troops: It was expected that the Mahdi would advance and crush him, while the increasing hostility of the Zanzibar Arabs and slave-traders made communication from the east coast very difficult. When, therefore, it was heard that a chest had arrived from Emin at Zanzibar, and was on its 
way to its consignee, the Director of the Natural History Museum, it was fully expected that some account of the military position, and perhaps an estimate of the time which his ammunition would last and of the spirits of his troops, would accompany the package. There was in it absolutely no personal news whatever. The letter and the contents of the chest were just what might reach the table of some learned society in London from a correspondent on the fringe of civilisation, who hoped to interest, and expected in the course of time to be back at his club, and able to give a lecture on his travels.

The box was an ordinary seaman's chest. The covering letter was exquisitely written on the very best foreign notepaper, divided into squares by the water-mark; and, as Flower said at the time, the only thing which seemed to cause Emin any anxiety was the doubt whether his contribution would or would not entitle him to be made an honorary fellow of the Anthropological Society.

\section{WadelaI, September 4, I 887 .}

DEAR Sir-Your very welcome note of Nov. 23 , I 886, reached me here safely. As by the papers I had learnt of your new appointment, $I$ have addressed the boxes which $I$ forwarded to you to the Consul-General, requesting him to send them to the British Museum of Natural History. By Mr. Mackay I was informed of his having started the said boxes from Uganda on the Igth March. They should, therefore, by this time have arrived at, and perhaps started from Zanzibar. On April 17 I wrote another letter, with four boxes of different objects to you, 
but owing to the war between Uganda and Unyoro two boxes were returned to me, and are still here. As towards the end of this month I despatch a caravan to Uganda, I hope to be able to send them by this occasion, together with the boxes of specimens which I collected during a short stay at the western shore of Lake Albert. There are some new species of birds which may prove acceptable to your collections. I have somewhat neglected to collect mammalia, for the reason of deficiency of books. By this post I entreated my friend Dr. Felkin to get me a good work treating of mammalia only. If, therefore, he begs your advice about the choice of the wished-for book, please give him the necessary directions. Remember, however, that the book is wanted for determination. Collecting without an approach to determinate is half-hearted work. For the first time I shall send some lepidoptera.

I have some good skulls for you ready-Lango, Wadi, and Turi, but I dare not send them now. The King of Uganda is in strained relations with Mr. Mackay, to whom I send my boxes; and if by chance they did open a box, and found these skulls, we should be accused of witchcraft, and of plotting against the life of the king. I may, therefore, be forced to expect Mr. Stanley's arrival; but if by chance an opening offers itself, I shall certainly send the skulls also. In my antecedent letter I begged of you to tell me whatever I could do for you and your collaborators. The English have proved so generous in my people's behalf, that I should like to contribute at least to your public collections. You write so many delightful things (vide "Osteology of Mammalia," etc), why not remember and gratify me with a copy? Believe you that we Africans have lost all appreciation of science?

Dispose of my services, and believe me to be, dear sir, yours very faithfully,

Dr. Emin Pasha.

Prof. W. H. Flower, LL.D., F.R.S.,

Director of the British Museum of Natural History.

Flower read a paper on these Akka skeletons before the Anthropological Institute in February 
I 888, which was published in the August number of the Journal. He also incorporated part of these remarks in a very interesting chapter on the Pigmy Races of Men in the second part of his Collected Essays. In this he traced in a connected form the whole history of the pigmies, as known in legend and to science from Homer to Haliburton, who recently discovered a race of dwarfs in Mount Atlas. Of a more popular character was his essay on "Fashion in Deformity," in which he applied his general knowledge of the induced deformities of all races, from the highest to the lowest, and left his readers to draw their own conclusions as to the advisability of letting nature alone.

After his death the Athencum of July 22, I899, contained a short supplementary notice referring to his share in advancing the zoological study of man. It is not much more than a catalogue, but may serve as a guide to other papers for which space does not allow even an abstract.

The death of Sir William Flower is so great a loss to Anthropology that it is fitting that the general tribute to his services to science, which has already been offered by the Athencum, should be supplemented by a notice in this column (Anthropological Notes). He had already made important contributions to anthropological research when he joined the Anthropological Institution in $1877 . \mathrm{He}$ at once became an active member, taking part in its discussions, serving on the council, and contributing to the Journal. He gave the Institution the benefits of his unrivalled knowledge by verifying the contents of its museum. 
After referring to the various activities mentioned in previous pages and noting his papers on the natives of the Andaman Islands, the writer adds :-

All those who have been his colleagues in the council of the Institute will recall the memory of his zeal in their service, his ready help when occasion called for it, and his wise counsel, which was available alike to the body at large and to the individual student.

Writing on July 16, 1903, Mr. Francis Galton says :-

Though our lines of study lay for the most part in different directions, and the statistical interests common to us both led to scientific opposition as regards the validity of methods, . . . I should like to take this opportunity of speaking most emphatically and most affectionately of his kindliness and courtesy. They were combined with sound judgment, strong common sense, and wide knowledge. He made one of the best of chairmen, and was, I think, more universally beloved by his contemporaries than almost any other scientific man whom $I$ have known. 
SPEAking at the unveiling of the late Director's bust at the Natural History Museum, the Archbishop of Canterbury said that among the qualities which he most admired in him were his enthusiasm for his work, and the way in which he contrived to interest others in the subject without ever boring them. Those who either accompanied him round his Museum by invitation on Sundays, or whom he met 'in the building, and who found before they were quite aware of it that he was gently making himself their guide, will heartily assent to this view. His Sunday gatherings there, before it was opened to the public, were particularly pleasant as social meetings and useful to the Museum, for the varied and very distinguished company who came to them spread interest in what was going on in circles whence effective help or support was frequently forthcoming for useful projects connected with Natural History. At the same time he was equally keen on interesting the working men and the leaders of democratic 
opinion in the same way, and enlisted their goodwill without difficulty. One day he appeared with Mr. John Burns, M.P., in Mr. Fagan, the Secretary's office, and, after introductions, said, "I met Mr. Burns going round the building, and thought he wanted a guide; so I ventured to propose myself; and I am glad to say that he expresses himself very well satisfied with what he has seen."

Among the visitors whom Flower more particularly enjoyed taking round his Museum was Lord Tennyson, who spent a morning with him alone on July I4, I 892. They were old acquaintances, from meeting in Dean Stanley's house at Westminster. On July 23, I892, Flower went down to stay at Aldworth, meeting the Duke of Argyll, who was also to be a guest there, at Waterloo, whence they travelled down to Surrey together. Flower wrote an account of this visit in his wife's note-book.

After a very lovely drive of nearly two miles from the station, mostly over wild common land and through deep lanes with woods on each side, we arrived at Aldworth. It is a handsome stone house, in the English style, built about twenty years ago by Lord Tennyson, Mr. James Knowles, now editor of the Nineteenth Century, being the architect. It stands close to the edge of the steep greensand escarpment, which runs nearly due east and west through all this part of the country, and immediately to the south is a steep drop of several hundred feet, and then a level plain, bounded nearly twenty miles off by the range of downs between Worthing and Portsmouth, giving a magnificent view. The ridge, and the whole slope below, is covered by an old wood, in a clearing in which the house was 
built, and through which walks were made in various directions, some of which lead down through the steep paths to a little farm at the bottom, which is part of the property. The house thus perfectly carries out one of the owner's principal objects in coming here in summer from the Isle of Wight-freedom from the intrusion of unwelcome strangers. The only approach is by a private road across the common, and then through the Aldworth woods and lodge, and neither house nor garden can be seen from anywhere.

The poet met us at the hall door, attired in his cloak and broad-brimmed felt hat. $\mathrm{He}$ had just been walking in the garden, and gave us a friendly welcome. Of course he was greatly pleased to see so old a friend as the Duke of Argyll, who had visited him annually for so many years except this last; so they had not met for two years, and had very much to say to each other upon almost every subject, especially recent politics. Mr. and Mrs. Hallam Tennyson appeared about the same time, and we were taken into the drawing-room to see Lady Tennyson, who was lying on a sofa. She was very sweet and kind in manner, but very frail-looking. They told me that she had not walked for thirty years. We then went out into the garden (it was a beautiful summer evening). The natural character of the old rough wood of oak and hazel has been completely changed round the house, and a great many conifers of various kinds planted, now fine, healthy, well-grown trees, in all of which Tennyson takes much pleasure and pride; and having planted them himself when he first came to the place, he is evidently much pleased to have them admired. They seemed to have grown much too luxuriantly in places, blocking out the splendid view. But, of course, I did not say so, as this could easily be remedied if necessary. . . . I was agreeably surprised to see Lady Tennyson walk in with the Duke. She sat through dinner, but retired very early upstairs, and we did not.see her again during the evening. Tennyson also retired soon after dinner to his library upstairs (between which and the garden he spends most of his time), and as the Duke also went early to his room, I was left alone with $\mathrm{Mr}$. and Mrs. Hallam. The latter soon took me off to his private room at the top of the 
house, where he smoked, and we had a long talk before we went to bed. Tennyson never comes down to breakfast with his family, but takes it in his library to avoid fatigue and to get more time to himself. But he gets up early, and while I was dressing I saw him pacing about the garden, stick in hand, and with cloak and broad-brimmed hat on. ... After our return from church at Haslemere we found the Poet Laureate, the Duke, and Hallam sitting in a summer arbour near the entrance to the grounds, talking most interestingly of poetry and of various criticisms on his (Tennyson's) writings, about which he seemed very sensitive, and asked our opinion as to whether they were just. The Duke talked much about birds, taking minute notice of every one he saw. Observation of natural objects around him is evidently a keen source of interest to him, and he has considerable general knowledge of such subjects. Tennyson also talked of natural history; the former geological changes of the world and the succession and extinction of animal life and evolution have a great fascination for him. He was very anxious for my opinions as to these questions, and their relation to belief in God's creation of, and providence in, ruling the world. These questions are touched upon in the new poems (not then published), which he showed us, and read some of (this was in the afternoon). He spoke very severely of those who tried to shake religious faith in others by irreverent treatment of sacred subjects, especially referring to some recent utterances of our friend —. But the subject which they both (the poet and the Duke) seemed to feel most keenly, and to which they constantly referred, was the political decadence of Mr. Gladstone, and the state he was bringing the country into by his action. They had evidently both been greatly attached to him in former times, and therefore felt the change which had come over him more acutely.

After luncheon the poet retired upstairs, and Hallam showed us a very fine phonograph which Edison had sent as a present to them, and from which he reproduced in a wonderful echo of the poet's voice several of the shorter poems, "The Splendour falls on Castle Walls" and "The Charge of the Light Brigade."

Later in the afternoon we found Lord and Lady Tennyson in 
the garden (she in a recumbent couch on wheels). He read some of his new poems, and then I ventured to ask whether he would not read one of his old ones. I suggested the "Ode on the Death of the Duke of Wellington," and he seemed pleased at the choice, and said he would read it after dinner. I told him that I had often read it to my children, whose first ideas of the Duke of Wellington had been derived from it, which also pleased him. He said, "I hope you pronounce it properly - all the vowels broad and long (larmentartion)." He had reproved the Duke in the morning for speaking of a "knŏll" instead of knōll, and said you would not say " tŏll " a bell. He thought the mincing way of shortening vowels was spoiling the language. But I must say the opposite extreme which he adopts, combined with his deep rough voice and Lincolnshire (?) accent, though interesting, was not really pleasing. He was very severe upon the impertinent intrusion into his private life of modern interviewers and newspaper writers.

Although generally rather severe and depressed, complaining of old age and weakness and of the political and social state of the country, he was often jocose in a grim way. The Duke was upon some particular diet, involving occasional drinking of a cup of hot water. When at tea Tennyson offered him some, and the Duke said, "Not yet; my man will bring it when the proper time comes"; to which Tennyson replied, "Oh, I see, he always keeps you in hot water."

Speaking of the Duke of Wellington, I asked him if he had known him personally, and he said that he had never met him but once, at an evening party, and that the host offered to introduce him, but that he declined, being, he said, very shy, and thinking that the Duke could not know who he was. Thereupon the Duke of Argyll gave several interesting reminiscences of Wellington, one of which may be worth setting down. A man in the Indian Civil Service had some grievance against the Company, having been, he alleged, wrongly deprived of an appointment, and was trying to get compensation. His case was brought to the notice of the Duke of Argyll, then very young in politics, and he promised to bring it before Parliament; but in order to get more support he went to the Duke of Wellington and laid all 
the circumstances before him. The Duke listened, and asked what he proposed to do. He said, "To ask a question in the House." "Well, and when your question is answered, what next?" "Well," the Duke of Argyll replied, hesitating, "that, I suppose, will depend upon circumstances," or something to that effect. Whereupon the Duke of Wellington said, "Let me give you a piece of advice, which I have always acted upon through my life. Never take any step without having clearly in your mind what, if it should succeed, the next step should be."

I expressed my admiration for the house and surroundings to Lady Tennyson, but she said it was not nearly as charming as Farringford, which she looked upon as really her home. She always longed for the time for going back there, and most kindly said, "I do hope you will come and see us there; I should like you to know the place." Hallam told me they were literally driven out of the Isle of Wight during the tourist season by the intrusion of strangers, who insisted on coming into the garden, walking up and looking in at the windows, and if they were stopped from doing this, standing round the gates, or climbing up trees with opera-glasses and telescopes to catch a glimpse of the poet. When they go out for a walk or a drive they crowd round them in a manner unpleasant for any one, but especially for one so peculiarly sensitive to such treatment as Tennyson. After dinner we all went up into the poet's library, a large corner room looking to the south-west and commanding a fine view. Then came the promised reading of the "Duke of Wellington." 1 He reclined sideways on the sofa, holding the book up in his hand, near his face, with a lamp behind. As he had been talking much during the day, and was suffering somewhat from a cough, Hallam begged him not to read, and I felt that I ought not to press him, as it was evidently an effort. But he was resolute, saying that he had promised me to do it, and so he would, and he read it all through, while the Duke and I listened with the deepest attention.

Hallam left the room because, he said afterwards, it was

1 It may be remembered that one of Flower's pleasures in life had been reading Tennyson's poetry to his family in the evening. Hence his peculiar enjoyment of the scene he describes. 
painful to him to see his father making such an exertion; but it was satisfactory to find that he was none the worse for it, and continued to talk afterwards with the greatest animation. One interesting circumstance connected with this reading was that when he came to the line

Who never sold the truth to serve the hour,

he paused, looked up, and said, "As I am afraid Mr. Gladstone is doing now."

The Duke and I had agreed to go by the same train to London the next morning, which involved our starting soon after breakfast, to which, as before mentioned, Lord Tennyson does not come. But we were both asked to go up in turn to see him in his library. We had a little interesting conversation, and he bade me a kind farewell, expressing a hope that I would come again to Aldworth. But three months afterwards I was one of the great procession of mourners in Westminster Abbey on Wednesday the $\mathrm{x} 2$ th of October. 


\section{CHAPTER XVI}

LATER DAYS AT THE NATURAL HISTORY MUSEUM

IN I 889 Flower achieved a typical year's work and activity. Besides his daily occupation at the Museum he lectured before various societies, and spent an Easter holiday in Cornwall, where, finding some unrecorded remains of whales at Penzance, he carefully examined them, found out their species, and fully described them for the local museum. He was elected President of the Zoological Society for the eleventh time. In addition to all his regular work a large correspondence, both at home and abroad, made increasing demands on his time and energy. Part was due to his position, and he was always ready to comply with legitimate desires for knowledge. But it was scarcely fair that many people should write to ask him for information which they could have found for themselves if they took the trouble to consult an encyclopædia. Many parents also sought his advice about the education of their children. He had to disappoint some mothers who brought boys who "had a taste for natural history," which often meant only that they were fond of catching butterflies, 
and wanted to leave school to obtain situations in the Museum. He used to astonish the parents greatly by recommending them to send them back to school to study Greek and Latin, after which they might be qualified to pass on later to the study of natural history. He spent August with his family in Switzerland, staying chiefly in the higher and lonelier parts, especially at the little Riederalp hotel, between the Eggischorn and the Bel Alp, exploring the magnificent Aletsch glacier. Nature had formed an ice grotto that summer on the glacier, which they frequently visited, and which was described in the words of their sixteen-year-old boy Stanley, who wrote home :-

We have seen the wonderful natural grotto, the most utterly and inexpressibly lovely and delicately beautiful yet awe-inspiring spectacle that I have ever seen. The blues and greens of the transparent ice, the pink light from the outer air falling on the waterfall, and the purple dimness in the spray and inner recesses of the vast cavern, combined with the majestic roar of the great cataract tumbling wildly into the abyss beneath, and the fantastic pillars sculptured by Nature's hand upon the ice, produces a scene the very ideal of beauty.

He was President of the British Association in September, staying with Lord Armstrong during the meeting, which was held at Newcastle. The substance of his presidential address has been dealt with in the chapter on "Anthropology." He was made a D.C.L. of Durham University, and then, after a series of visits, including one to the Duke of Northumberland at Alnwick Castle and another to 
the Earl of Tankerville at Chillingham, ended the summer by taking his youngest boy, Victor, to Winchester. In 1890 he began one of his most popular series of lectures, those on Saturday afternoons at the Royal Institution. The subject was the "Natural History of the Horse and its Extinct Allies." These were very largely attended. The treatment of the subject was new to his hearers, while his great knowledge of the present structure of the horse and of its evolution was very welcome to all classes and sexes interested in riding, driving, training, and breeding all kinds from "Shires" to Shetland ponies.

On April 30 the Civil Service dinner was held, at which Lord Wolseley was in the chair and Flower Vice-chairman. Flower responded for the Civil Service in one of the brightest speeches which he ever made, and before a highly critical audience. He declared that he was "almost the youngest member of the Service there, having been only appointed six years, but that he brought to it the proverbial zeal of those converted late in life. Instead of devoting his time to the study of mammals and the craniology of Andaman Islanders, he had found a far higher vocation, the study of man in his highest development, whose habits and idiosyncrasies had to be studied, whether engaged as colleagues at the Natural History Museum or in the Dread Department (i.e. the Treasury), the name of which must not pass his lips, which 
sat in judgment on them all, and gave or withheld the means of encouragement to all." He particularly referred to the measure for retirement being brought forward, "under the provisions of which, at an age when bishops are appointed to rule great dioceses, and at which politicians were spoken of as rising men, the knowledge and experience of a civil servant will no longer be at the service of his country." In November he attended the public transfer of the Booth collection of birds to the Corporation of Brighton. In the following year he published his Introduction to the Study of Mammals, Living and Extinct, in which he was assisted by Mr. Lydekker.

His eldest son Arthur, who was educated at Winchester and Oxford, in accordance with his father's views on the subject of the best general education, and had taken up the profession of an architect, was, to his father's great pleasure, married on the 24th of June 1892 to Alberta Maitland Chambers, youngest daughter of Dr. Thomas King Chambers, and a god-daughter of the King.

In 1892 he brought together his lectures on the horse in a book entitled The Horse, a Study in Natural History (Kegan Paul), published as part of the "Modern Science Series." It was a subject which appealed to every class of reader, scientific or otherwise. It was the first of the series, and dealt with the history of the animal "as it appears 
in the modern and now generally accepted doctrines of Natural History." In the first part of the book he traced the history of the group now represented by the tapirs, rhinoceroses, and horses step by step, as shown in the fragments preserved from former ages, farther and farther back into time, these differences continually becoming less marked, and ultimately blending together, if not into one common ancestor, at all events into forms so closely alike in all essentials that no reasonable doubt can be held as to their common origin. The second part of the book is devoted to the anatomy of the horse and its nature and habits. In his second chapter he was at pains to add :-

Those who have the care of horses in a domesticated state may learn a practical lesson from what has been here said as to their habits in a state of nature. All existing species of the family are dwellers in dry, open, and generally elevated plains. None are inhabitants of gloomy forests or reeking marshes. Fresh air, dryness, and light are essential to their well-being. Darkness and damp, which some animals delight and thrive in, are utterly uncongenial to horses. The neglect of this consideration, so frequently seen in the construction and management of stables, is not only unkind to the animals, but very costly to their owners.

He noted that in Egypt there was no trace of the domestication of the horse before I900 B.C., long after the ass had become a servant of man in the valley of the Nile. Bailey's Magazine, a periodical devoted almost entirely to hunting, riding, and driving, in a review of the book on practical modern lines, says : "Especially would we commend 
to horse-owners the page (I4I) dealing with the anatomy of the horse's head and neck. After explaining how the heavy head is supported by very slight muscular exertion, the author says: "Probably if those who have to do with the harnessing of horses were better acquainted with this admirable, natural, mechanical apparatus for holding up the head in a natural and unstrained position, they would think it less necessary to supplement the cervical ligament by an external contrivance for effecting the same object, called the 'bearing rein,' which, however, not being elastic, never allows the head, even momentarily, to be altered in position."

Thus Sir William was able to support on scientific grounds the views so strongly held and advocated by his father, Mr. Edward Fordham Flower, in the later years of his life. None of the Flower family ever allowed the use of bearing reins, either those settled at Stratford, the inmates of whose stables were well known throughout the county, or Sir William or his father in London.

On August 28, 1892, Flower received an intimation that he was created a Knight Commander of the Bath. The letter was written by Lord Salisbury, and ran as follows :-

MY DEAR SIR-I have much pleasure in informing you that the Queen has been pleased to direct that you should be appointed a Knight Commander of the Order of the Bath, in recognition of the valuable services which you have rendered during your tenure of the post which you so worthily occupy.

I need hardly say that it is a matter of great satisfaction to 
me to be the instrument of conveying to you Her Majesty's gracious command.--Believe me, yours very faithfully,

Salisbury.

That autumn Flower was summoned to Windsor Castle, where Queen Victoria graciously presented to him the insignia of the Bath.

The recurrence of the London season always brought extra work by multiplying engagements. Flower was the reverse of a recluse, and greatly enjoyed congenial society, sometimes saying laughingly to his wife that "he was glad he was not a genius, as he was sure that she would not have found a genius pleasant to live with." $\mathrm{He}$ was much in society, besides attending the functions of the various learned bodies with which he was associated. He did not care for the heated atmosphere of large and late evening parties, but found garden-parties more to his taste, especially those held among the historical associations of Lambeth Palace, or among the trees and flowers of Syon House and Osterley, while in London itself he had the privilege of attending the gardenparties of Her Majesty at Buckingham Palace, and of the Prince of Wales at Marlborough -House. But undoubtedly the most interesting of all these social experiences was when Flower and his wife and daughter were invited to Balmoral Castle, and enjoyed the privilege of private conversation with Her Majesty the Queen in September I894. Lady Flower writes: "Although my husband was 
so tall and the Queen so short, he said that Her Majesty had such dignity of carriage that he was not conscious of her being below the ordinary height, and was principally impressed by the beauty of her clear voice, and by the degree in which her appearance excelled her portraits, she having such a well-shaped handsome nose, as well as such blue eyes. The Queen proved her 'Royal memory' indeed in remembering all about our friendship with the Dean of Westminster and Lady Augusta Stanley, and graciously inquiring after our children, who had been christened by him, and showing such kindness generally as to remove all formality and give the real pleasures of conversation. Her Majesty also said with how much pleasure she heard of the progress of the Museum from various members of her family, and only lamented that increasing lameness must prevent her from visiting it herself. But it is sad to look back on that most interesting dinner-party of twelve and remember how many are already gone. On each side of the Queen sat Prince Henry of Battenberg, looking well and handsome in Highland costume, and Prince Christian Victor of Schleswig-Holstein, just returned from his Indian campaign, of which he spoke with much animation and enthusiasm. Both young Princes have since died in the service of their country, as well as our beloved Queen herself, "full of years and honours.'" 


\section{Lady Flower says :-}

One beautiful summer day was greatly enjoyed by my husband, when H.R.H. Princess Louise (then Marchioness of Lorne) was so kind as to show Windsor Castle to us. The art treasures were thus seen under peculiar advantages, the Princess herself having such artistic tastes and powers, and describing pictures, sculpture, miniatures, historic rooms with intimate knowledge of all, both artistic and historical. The views from the windows were as lovely as anything, and H.R.H. even led us out of a window on to a roof, whence there was a magnificent viewWindsor Park in all the freshness of its foliage, with blue distances beyond, as well as the interest near at hand of Eton College.

In 1894 Flower was elected a member of "The Club," a social institution of an interesting kind. It was founded in 1764 by Sir Joshua Reynolds and Dr. Samuel Johnson, and among its original members were Charles James Fox, David Garrick, Richard Brinsley Sheridan, and Edward Gibbon, and Adam Smith. Flower was elected at the same time as Lord Lansdowne and Lord Davey. Among a long list of distinguished members at the time were Lords Rosebery, Kelvin, Coleridge, Acton, the Marquis of Salisbury, the Marquis of Dufferin, the Duc d'Aumale, Mr. Gladstone, Professor Huxley, Lord Leighton, Lord Wolseley, the Bishop of Oxford, Mr. W. H. Lecky, Viscount Goschen, Sir Robert Herbert, Sir Alfred Lyall, Sir Donald M. Wallace. The Right Hon. Sir Mountstuart E. Grant Duff was Treasurer. 


\section{CHAPTER XVII}

\section{LAST YEARS AT THE MUSEUM}

Mr. Charles Fagan, the Secretary of the Natural History Museum, was naturally in receipt of many private letters from his chief when the latter was away on his holidays. Most of these are of a personal character, or are concerned with official matters on which it would possibly not be desirable to publish his opinion. But the following, selected from a number which $\mathrm{Mr}$. Fagan has kindly placed at my disposal for use in this Memoir, will give an idea of some of the matters which daily engaged the Director's attention at the Museum or when he was away for his holidays :-

York, August 26, 1894. 2

MY DEAR FAGAN - . . . I was very pleased to find ready to take up a piece of work in the Hall, and told him I would give him all facilities in the way of specimens or materials, but that I could not apply again to the Treasury for any overtime allowance. About this, however, he made no difficulty, and if he

1 In this year a notice of his late friend Sir Victor Brooke's researches in natural history was contributed by him to Sir Leslie, then Mr. Leslie Stephen's Life of Sir Victor Brooke. 
continues to carry it out as he proposes, I feel sure it will be a good thing and do him credit. I shall be glad to have all the specimens he requires ordered from Naples.

Writing from Avonbank, Stratford-on-Avon, on April 9, I896, he says :-

I am glad to see those cuttings. That from the Times, which I had already seen, is far the best; and I like the notice in the Daily Neres of Waterhouse's Life Histories of Insects, which are some of the best things that have been added of late to the public exhibition, and will become still more valuable as the series increases. . . . What you tell me of your Italian friend is very interesting, and I am glad you have written to Salvadori about him. If he really stuffed that elephant, he must have some genius for the work that we should do well to develop.

\section{On August 7 of the same year he wrote :-}

My DEAR FAGAN-I have this afternoon received your letter

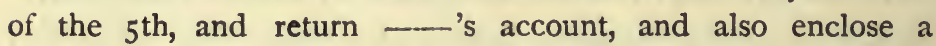
Spanish letter about our publication, which you will probably be able to make out and have attended to. I am not surprised that the Office of Works declined to cut the terra-cotta skirting, as the case can easily be adapted to fit the recess. As to the ducks, ${ }^{1}$ - made a great mistake, for I had particularly asked Lord Walsingham to send some on the Ist and I $5^{\text {th }}$ of August and the ist September. But one came shortly before I started, and coming at an irregular time, and being an old female, I did not want it stuffed (I mean mounted by Pickhardt), so gave it to - to eat. But I did not mean this to apply to future consignments! If not given for mounting, the skins should be kept. Thanks for the Daily Telegraph with its account of the Museum. I saw the number of visitors in the Times, but had forgotten that there were so many last August, and thought they must have made a mistake. I am glad that the Sunday visitors keep up in numbers. 
He writes from St. Antönien, Switzerland :-

We have been here just a fortnight, and have had our first really fine day. If it goes on like it is now, we shall soon forget all we have been through, and thoroughly enjoy the place, for it is ' most beautifully situated, with charming walks all round, and quite comfortable enough within for all practical purposes; all new and clean, though plain, and the living is substantial and abundant, and we are all getting well and strong. The principal difficulty about the place, and what keeps it still in a primitive condition (especially as to prices), is the difficulty of getting to and from the station, 5 miles off. . . Whenever the sun has shone insects have been abundant, and I have nearly filled the collecting box Austen provided me with. Will you send me out another by return of post, if possible, and ask to have put inside two or three small setting boards, suitable for diptera and beetles, and also some more cardboard discs, for I have come to the end of those I brought out, and I want them all to be alike? I have plenty of pins and everything else required.

I suppose you have seen Mr. -'s speech about our salaries, full of all the fallacies and ignorances of the subject usually shown, and which has unfortunately not been answered. But it gives a good opening for returning to the attack, which must be taken up seriously before the estimates are sent in. . . . But I must not go on about things which I ought (for a short time) to put off my mind. It was reading __'s speech in the Times that set me on. . . .

In January 1897, when the state of Flower's health was becoming serious, he wrote from Marazion :-

My DEAR FAGAN - I received the enclosed this morning from Sir Edward Thompson, who asked me to send it on to you. As far as I can make out, it corroborates your original idea that we are to have no reductions, ${ }^{1}$ and that the Treasury have therefore been very liberal to us. . . . It is satisfactory that our Purchase Grant

1 In the grant for the Museum. 
is assured for five years, though, judging by past experience, there is not much chance of our "building up a fund." Sir Edward writes very kindly to me, strongly urging me not to think of returning for the Trustees' meeting of the 27 th of February, and offering to take the business of the meeting himself. I must wait a little before I can decide. Of course, I very much want to be back, and yet, on the other hand, I am not getting on quite so fast as I hoped.

It is pleasant, though rather pathetic, to note how frequently in those last letters he wishes that he could be back in his beloved Museum, if only for a few hours :-

I wish that I were going home, and was able to walk into the Museum, but I am afraid it will require this other month (March 1897) before it will be safe to do so; and then I shall have to begin by degrees before falling into my regular work.

And again :-

I often wish to know something of all that is being said and done in the Museum, but I find it necessary for my peace of mind and health to think as little as possible of it at present.

I suppose you have been able to pay for the pedestal [of the Owen statue] this year? [The sculptor] will want the rest of his money, but until I can get at work winding up the accounts, which I must do soon after my return, I cannot say exactly what it will be. Should he say anything about wishing payment I could send him a cheque from my own bank, though it may make a little confusion.

Artists who are kept waiting for payment for work done will appreciate this last considerate offer.

In February 1898, though able to go to the Museum, he was evidently very unwell :-

I had a good day at the Museum yesterday (he says on February 18), but stayed too long in the Entomological and 
Taxidermist Departments downstairs. Consequently I had a bad night, and am not good for much to-day. It is very provoking, for I am afraid I ought not to come back till Monday.

It happened much as I expected when I saw that an exChancellor of the Exchequer was at the meeting on Saturdaycould not stand the Treasury letter, and insisted on declining to comply with their reduction. It will not lead to any good, I am afraid.

The appointment of his son, Captain Stanley Flower, to the management of the Zoological Gardens at Cairo gave him great pleasure :-

I enclose a letter from Stanley (he writes on August 27,1898 ) about a box which must now be on its way to the Museum. When it arrives will you please have its contents distributed according to the list enclosed. I mentioned to you before I left that he might be leaving Bangkok soon, and now I am glad to hear that he has received the appointment of Superintendent of the Zoological Gardens at Cairo, one which is entirely to his taste, and which will be a far more agreeable and healthy place of residence for himself and his family. $\mathrm{He}$ is to be there in October. The Zoological Congress seems to have been well attended; judging from the newspaper reports, most of the foreign nations are well represented. I hope that the London part will be successfully carried out, and that the Museum will be appreciated.

In October I 898, after the Director had sent in his resignation, he wrote among the last letters of this correspondence :-

My DEAR FAGAN - Your letter of the Ist gives me real pleasure. I will keep it among other valued testimonies that my life during the last fourteen years has not been spent altogether in vain. The constant help you have given me throughout is one of the most agreeable memories connected 
with those years. You know how much I wish I could have done more, both for. the Museum and for all belonging to it. But it has not been granted to me, and I must be thankful for the measure of health and strength which is left.

Though the work entailed at the Museum by his undertaking the keepership of Zoology made great demands on his thought and time, Flower received ample public recognition of his efforts, while his private life was singularly happy. $\mathrm{He}$ was elected an honorary member of nearly every learned society abroad connected with Zoology. $\mathrm{He}$ was already an honorary LL.D. of Edinburgh and of Cambridge. In 1895 he received the honorary degree of D.C.L. at Oxford. In September 1895 , at the International Congress of Zoologists at Leyden, he was elected President for next year's Congress. The University of Utrecht made him Doctor in Botany and Zoology, honoris causa, in the same year. He was elected a Life Trustee of Shakespeare's birthplace by the people of Stratford-on-Avon. In 1897 he was elected "Associé de l'Academie Royale des Sciences, des Lettres, et des Beaux-Arts" of Belgium, the only other British Associates being Lord Kelvin, Sir J. Hooker, and Sir Archibald Geikie. In 1898 he received through the German Embassy in London from the German Emperor the Royal Prussian Order of Merit, "für die Wissenschaften und Künste," which the Queen granted him permission to wear.

But Flower's constitution, though his fine appear- 
ance did not show it, was already beginning to feel the effects of strenuous work and responsibility. In I 897 he notes in his skeleton diary, "I began the year in my serious illness, not having been out of the house since December 10." Lady Flower has described in the final chapter the way in which he maintained his interest in his work and administrative duties under the heavy disadvantage of rapidly failing health. But on June I I, I898, his resignation of the office of Director of the Natural History Museum was received by the Trustees, to date from the 3oth September following. The Trustees received this communication with the greatest regret. The following letter was directed to be sent to Sir William, and signed by the chairman of the meeting, Viscount Dillon.

Dear Sir William Flower-With profound regret the Trustees accept the resignation of the Directorship of the Natural History Museum, which, owing to failure of health, you have unhappily been compelled to submit to them. They had hoped that the remaining term of years which you might have spent in their service would have enabled you to perfect the arrangement of the collections so admirably planned and so systematically developed by you during your fourteen years of office, and they cannot but regard your retirement at this moment as a real misfortune to the Museum. They wish to record their high appreciation of your services. The rare combination of wide scientific knowledge with marked administrative ability and sympathetic appreciation of the requirements of the uninstructed public has carried you through a most difficult task. Under your hands the Natural History collections of the British Museum have fallen into the lines of an orderly and instructive arrangement, which no one, whether man of science or ordinary visitor, 
can examine without admiration. To you, as a worthy successor of Sir Richard Owen, will attach the honour of having organised a museum of Natural History which now occupies a pre-eminent position among all Museums of the civilised world.

For these devoted services the Trustees thank you. In your retirement you carry with you their lasting gratitude and sincere good wishes.-Believe me, dear Sir William Flower, yours very truly,

Dillon. 


\section{CHAPTER XVIII}

HIS LAST YEARS

BY LADY FLOWER.

THE latter part of life is often spoken of as "going down hill," but with Sir William Flower it was more like the sun setting after a beautiful day; for all that had distinguished his life in its rise and progress shone forth even more towards its close, just as the sunset brings out lovely colours, lights, and shades unnoticed before, till we feel almost as if this earth were being transfigured into heaven.

His devotion to duty, his love of work, his keen interest in science, in politics, in fact in all things, both public and private, that bore upon the progress and good of mankind, his own patience under trials, his consideration for others, his love of his family, were only intensified as his physical strength declined. The sufferings of illness were to him "crosses" to be borne with resignation and cheerfulness. When in 1897 the doctors first told him of serious mischief threatened by his heart, he said to his wife that he "only hoped that it would not make him irritable or troublesome to others." His aspiration was fulfilled, it never did. 
Already in 1896 the strain of work had begun to tell on his health, and as mountain air had hitherto done him good, a journey to Switzerland was again undertaken, though this time only to quiet unfrequented parts. He was much interested in collecting Natural History specimens for the Museum, and as keenly alive to the beauties of Nature as ever; but walking up-hill brought on breathlessness and palpitation of the heart, so that he was glad to return quietly home.

$\mathrm{He}$ had to relinquish what used to give him great pleasure, visiting interesting friends in beautiful country places, as when both stayed with Earl Cawdor in his picturesque old Scotch home, Cawdor Castle, with the Duke and Duchess of Northumberland in Alnwick Castle, with Mr. Webb in Byron's old home, Newstead Abbey, with Lord and Lady Tankerville at Chillingham, where he was presented with one of the famous "wild cattle" for the Museum, with Lord and Lady Tollemache in the moated Helmingham Hall, and other places of historic interest; but this autumn we only paid short visits at short distances from London, just for the refreshment of a country Sunday after the week's work. Thus we first went to Lord Avebury (then Sir John Lubbock) in Kent, and another week to Sir Trevor Lawrence to see his wonderful orchids in Surrey. But although enjoying these visits as much as ever, he was no better in health and becoming alarmingly thin, till, whilst on a short 
visit (for the Museum work had been hitherto steadily carried on between whiles) to Sir Henry Smyth at St. John's Lodge in Buckinghamshire, severe signs of heart trouble came on, and he hastened home to London, where Sir Richard Douglas Powell and his skilful doctor and friend, Mr. Kingston Barton, ordered complete rest for the time, and the Trustees of the British Museum were most considerate and kind in according leave of absence for as long as his health required it.

In January 1897 he sought quiet sea air in accepting Lady Warington Smyth's kind loan of her sea-side cottage at Marazion in Cornwall, where St. Michael's Mount is always an object of great beauty and interest, and Lord St. Levan kindly arranged for his boatmen to carry Sir William up the rocky ascent.

Afterwards he went to Colonel and Mrs. Biddulph in Ireland, where he obtained so much benefit from the pure air and peaceful quiet that hopes of his recovery were entertained, and, returning to London in the spring, he recommenced work in the Museum. Indeed, considering the dangerous illness which he had passed through, it was wonderful to see the quick step and animated gestures with which he would point out new specimens or explain improvements which he hoped to make. He never spared himself in going up and down stairs in that great building, or in working for it at home, even when a palpitation of 
heart necessitated his lying down for some hours. His friends urged his resigning the post in order to take complete rest, but the doctors did not consider it necessary so long as he gave up social engagements, and thus could have quiet evenings. His great interest in every department of the Museum, as well as in every man in it, seemed to work like a tonic on his health in enabling him to carry on his duties, assisted most loyally by the staff, one of whom said that "an hour of Sir William Flower was of more value to the Museum than a whole day from any one else." Thus encouraged, he struggled on and completed the "Whale Room," which he had ardently longed to add to the Museum. The Cetacea, necessarily unseen in the ocean, were now for the first time displayed in a manner that all could see and understand-by help of the labels, over which he took the greatest care and trouble, composing them even when awake at night, reading to his wife what he had written in pencil in the intervals of pain, so anxious was he to stimulate the interest of the public and to convey as much information as possible, consistent with the brevity necessary for printed labels. Thus the collection grew, even whilst its originator's strength declined, reminding one pathetically of Michael Angelo's lines,

The more the marble wastes,

The more the statue grows.

And this was still more true of his character. $\mathrm{He}$ 
never dwelt on his sufferings and privations, but often spoke with gratitude of the "mercies and blessings which had made his life so happy," and of having "been spared the pang of ever losing a child or grandchild," to the unspeakable comfort of his otherwise broken-hearted companion.

Preparations for the meeting of the Trustees became now trying work, yet he was always relieved afterwards, finding such appreciation of all the good work done in the Museum; and the King, then Prince of Wales (the Queen's Trustee), would often stay on afterwards alone with Sir William Flower to see more of the Museum, showing his personal interest in its welfare. On March $3^{\mathrm{I}}$ he attended the levée for the first time since his illness, and he was touched by the kindly welcome he received; indeed he laughingly remarked afterwards that the "Royal touch" that used to have such healing virtue was still efficacious, as he was none the worse for the fatigue, and at work again in the Museum next day. On the 3 Ist of May he received through the German Embassy, from the Emperor of Germany, the distinguished order "Pour le Mérite," founded by Frederick the Great, which explains its French title. This honour was all the more welcome as the only other Englishmen then having it were his friends Lord Kelvin, Lord Lister, and Sir John Murray for science, and Bishop Stubbs of Oxford for history. A letter from Lord Salisbury soon followed conveying the Queen's 
gracious permission for Sir William Flower to wear the insignia of the order.

This spring he was re-elected President of the Zoological Society for the twentieth year; he had often desired to resign, but the Council would not hear of it, a mark of consideration which touched him deeply.

However, in June he made the most important resignation, that of the directorship of the Natural History Museum. This was a severe wrench, for he loved the Museum and all its interests keenly, but as the palpitations of the heart increased in frequency and in duration he feared not being able to do full justice in his work, and so sent in his resignation to the Trustees, though he still continued to work there whenever health allowed.

On June I 5 he was able to show the new Whale Room to Lord Kelvin and a party of friends, who were all astonished and delighted with this original display of the Cetacea "in their habit as they lived," with thëir actual skeletons as well, thus preserving exactly their dimensions as well as other characteristics. Again on July I he conducted friends over the Museum. A pathetic interest is attached to this meeting as the last of the kind, after many years, in which these gatherings had been one of his special pleasures in life. Those present were the Minister for the Netherlands, Baron Van Goltstein, the Danish Minister, M. de Bille, Lord Ludlow and Lady Hanham, the Mar- 
quise de San Carlos, Sir Francis and Lady Jeune, Sir Clement and Lady Markham, Lady Morris, Lady Jane Taylor, and Mrs. Holman Hunt. He always undertook any amount of trouble to enable people to enter into the beauties, and also to understand the reasons for the number of specimens in the national collections. His singularly pleasant voice and readiness to answer questions greatly facilitated this, whilst his own strong interest in the subject made it attractive to others. As Mrs. Vaughan remarked in the College of Surgeons Museum, "Professor Flower always handles bones as if he loved them."

His family dissuaded him from undertaking more of this extra work, as prolonged standing and continuous talking brought on palpitation. Still he continued his duties in the Museum whenever physically able, and was always glad to welcome Mr. Charles Edward Fagan, the able and valued secretary of the Museum, and any others of the staff, for desired consultation in his house, Stanhope Gardens, conveniently near the Museum.

With his friend Sir Edward Maunde Thompson his relations were always most cordial, they both having the interests of the British Museum so much at heart; and when his illness increased, no one could have been more kind and considerate than the Chief Librarian in doing all he could to spare Sir William effort and exhaustion in the "Trustee meetings," whether at Bloomsbury or 
the Cromwell Road, and in softening the final separation.

The manner in which the Trustees received his resignation could not but be very gratifying to him and his family. Besides the official acknowledgment of his services, already noticed, many private letters reached him, among others from the King and the Archbishop of Canterbury, expressed so warmly that, in his sensitive condition, they brought tears of gratitude to his eyes. The King (then Prince of Wales) wrote that, "both on private and public grounds, it is a matter of deep and sincere regret that you felt yourself obliged to resign your post;" whilst others of the Trustees wrote with deep appreciation of all that he had done for the Museum, both by work and personal influence.

That summer of 1898 was spent again in Ireland, under the hospitable roof of his son-in-law and daughter in King's County, and he became so much better with the rest and open air that it was arranged that he should winter on the Riviera, so as to be able to continue living in the open air in a sunnier climate. My husband had long wished to visit that beautiful country, but had hitherto always been too busily engaged in London to absent himself in the winter; and although now not equal to making all the necessary arrangements, our daughter Geraldine proved invaluable and as competent as any courier, as well as a gentle companion, always contented, and always making the best of 
things, whilst the young Augusta ("Star"), born twenty-one years after her eldest brother, added much gaiety and brightness to the travellers. He stayed first at Cannes, but San Remo was our headquarters. A letter thence to our eldest daughter, Mrs. H. C. Shann, shows how much he enjoyed the place and surroundings, and how keenly alive he remained all through his illness to general interests.

Hotel Royal, San Remo, January 3, 1899.

My DEAREST MARY-Here I am sitting by the wide-open window, with a brilliant hot sun shining in, its power greatly increased by the dazzling reflection from a wide expanse of sea which our high-up rooms command. It really seems as if winter (two days of overcast and windy weather) was over and full summer set in again, but of course we cannot altogether expect this, and know that when the sun goes down into the sea amid gloriously coloured clouds, as is usually the case, a keen, crisp feeling (which I like, though it does not suit the pulmonary weak people) will pervade the air. That it never can be really cold here (however much people complain of it) is proved by the wonderful out-of-doors vegetation, trees, shrubs, and flowers, and fruit, the beauty of which is quite beyond my expectation. I should explain that this is due, at all events at the time of year, to the careful gardening, so much having been done of late years to introduce so many kinds of exotic plants, palms, india-rubber trees, pepper trees, eucalyptus, mimosa, aloes, yuccas, pricklypears, oranges, lemons, and numbers of others, the names of which I do not know at present, which must have greatly changed and beautified the place to what it was thirty years ago. The gardens round some of the hotels and private villas are like visions of Paradise. I have many letters to thank you for, especially the last long one of Christmas Day with the "Holy Family" almanac. It is pleasant to hear of all the kind and useful presents you have had, and of all your Christmas doings, 
very different to ours, as you will see in the San Remo journal which Star is sending. Your little Vera's robin is adorning the mantelpiece of my room, please tell her and thank her, and give my love to all four children, as well as to $\mathrm{Hal}$ and your dear self, and with all good wishes for a prosperous year in every way from mother and the sisters here, your ever very loving father,

W. H. FlOWER.

His two youngest daughters were with him on the Riviera, and his youngest son part of the time, so that with constant letters from the elder married children, it was altogether a happy winter, especially with his intense satisfaction in Lord Cromer's appointment of his second son, Stanley, ${ }^{1}$ to the Directorship of the Government Zoological Gardens at Giza, and the energy with which he set to work amid grave difficulties. Stanley had before been "seconded" from the Northumberland Fusiliers for special scientific work at Bangkok, but found that leaving Siam for Egypt was like passing from darkness to light. His father kept some of the letters on this subject under his pillow for re-reading in the wakeful watches of the night caused by illness. Still, with the light of morning always came the beautiful effects of the orange-coloured sunrise over the dark blue waters of the Mediterranean; then followed a day of flowers, hedges of roses in full bloom at Christmas, drives to the many interesting places along that historic coast, and inland through the soft green olive-woods (well described

1 So named after his godparents, the Dean of Westminster and Lady Augusta Stanley. 
by E. B. Browning as "the mystic floating grey"), contrasting with the yellow oranges and lemons, to the wonderfully picturesque old towns, and villages, and churches, returning to the exquisite sunsets over the sea, visible at this time of year from the same balcony as the rising. Then in the evening there was sometimes conversation with friends and acquaintances in the hotel, sometimes music, but generally reading by the little wood fire in our own rooms, which gave much quiet enjoyment. Yet his last happy day was approaching, the last one entirely free from pain. It was the $14^{\text {th }}$ of March that we drove to Ventimiglia to carry out his long-desired wish of visiting Sir Thomas and Lady Hanbury in their world-famed garden "La Mortola." Everything was as beautiful as could possibly be, the weather perfect, the magnificently cultivated garden, backed by wild olive-clad hills, with fine ranges of mountains beyond, whilst promontories running out into the Mediterranean on either side of the garden added to the interest of the scene, and the brilliant sun shining on the exquisitely picturesque boats and sails, and brought out opalescent colours in the waves which fell with soothing sound on the beach below where we stood. Still it is the garden itself which is unique; in that climate where everything can grow, the owner yet employs thirty-five gardeners to have perfection, and above all, being himself an enthusiastic botanist and horticulturist, he has made this spot of earth more 
lovely than words can describe; and Sir Thomas told us that it was "the day of the year when there were more flowers than at any other time." He explained most interestingly all we wished to know about the exotic trees and flowers, hospitably entertained us in the old "Palazza," and was so considerate as to have some of his gardeners ready to carry Sir William Flower in a chair up the steep paths of the garden to his carriage. We had a cheerful drive along the Corniche Road back to San Remo, and next morning he said that not only did he not feel fatigued but "better for knowing La Mortola," so that it gave hope again of ultimate recovery. Yet on the evening of that very day a sudden fainting came on, and for many anxious nights and days he was dangerously ill; but Dr. Michael Foster ${ }^{1}$ was unremitting in his attentions, and gradually the precious health was so far restored that my husband was able to undertake the journey to England (accompanied by Mr. H. C. Shann of York), by way of Milan and the Italian Lakes, another long-cherished wish; and the loveliness of Lago Maggiore in the sweet spring days of April induced a prolonged stay at Stresa, though increasing palpitations of the heart and consequent breathlessness became very alarming. One night he awoke feeling so weak, that with his own medical knowledge he thought "failure of the heart" was imminent; but even then preserving his usual calm and his usual

1 Son of Sir Michael Foster, Treasurer of the Royal Society. 
consideration for others, he would not wake his wife, who had been up several nights tending him, but opened his Prayer-book and left it open at the "Nunc Dimittis"-

Lord, now lettest Thou Thy servant depart in peace,

thinking, as he afterwards told her, that should she find that he had passed away in the night, these words might be comforting. $\mathrm{He}$ also drew her attention to words that he said expressed his feelings, "Love cannot end at death. It must last for ever and ever. It must grow better, and purer, and stronger, until at last it is perfect in heaven."

$\mathrm{He}$ came home by short stages, resting at Lucerne, Basle, and Brussels, and although weak and suffering he kept marvellously cheerful through the long railway journeys, quite interested in passing from Italian sunshine and the songs of nightingales through the St. Gothard tunnel, and finding large flakes of snow falling over the already snow-laden pine trees of Switzerland. He constantly recalled incidents of his early travels for the amusement of his children, as well as historical incidents of what were for so many centuries the battle-fields of Europe in France, Germany, and the Netherlands.

Finally he reached Stanhope Gardens on the 8th of May, and enjoyed a brief space of joy and hope in the quiet and comfort of home. But the palpitations still continuing, the doctors urged complete rest for the patient, and that he should not see any one 
beyond the members of the family in the house. No words can sufficiently express the devotion and skill with which Mr. J. Kingston Barton, with the sympathetic assistance of Dr. White Cooper, attended Sir William, warding off danger, alleviating pain, suiting the treatment to the daily varying phases of the illness, and, notwithstanding its increasing gravity, keeping up hope through all the trying days and nights, whilst Sir Richard DouglasPowell generously gave the advantage of his great experience and knowledge in frequent consultation.

Happily the love of reading which had characterised him all through life continued, so that he would often comfort those about him by saying, "I am glad of leisure to read" this or that book; "you can go out feeling that you are leaving me perfectly comfortable," and more of such reassuring words. He liked to have the Times every morning, and the Spectator and Nature every week; whilst even in his last month on earth he read through the whole thick volume of the Life of Lord Cromer, making comments on it to his wife, or if she were absent from the room, putting in a marker to anything specially interesting. He also read Froude's Story of the Armada, and the Cruise of the "Cachalot," by Frank T. Bullen, drawing attention to parts about whales that interested him, and greatly admiring the graphic description of the effect of the sublime words of the Church of England Burial Service, even read by 
and among rough sailors in a "Burial at Sea." He enjoyed having poetry read aloud, especially favourite pieces from Tennyson, and even in the last week, when feeling too weak for exertion, he asked for some of "the familiar lines of :Scott." At night he was always glad to hear Bishop Ken's old "Evening Hymn," Newman's "Lead, kindly Light," "At even ere the sun was set," and specially the "Abide with me, fast falls the eventide." 1

But these last days are too sacred to be fully described, only it is a duty, however difficult, to lift the veil sQ far that those who "come after" may benefit by such an example, as well as right, in justice to the constancy of his character, to record how steadfast he continued through all trials, so that even the sick chamber was illumined by love and faith to the end. "The interior beauty of a soul through habitual kindliness of thought is greater than words can tell. To such a man life is a perpetual bright evening, with all things calm, fragrant, and restful. The dust of life is laid, and its fever cool. All sounds are softer, as is the way of evening, and all sights are fairer."

His friend, the Rev. Gerald Blunt (Rector of Chelsea) came to read the "Visitation of the Sick," and when leaving the room he exclaimed, "I never knew before how beautiful Sir William is"; and so he was, the noble head lying back on the pillows,

1 One of his most frequent visitors was Lord Eustace Cecil, who never failed to raise his spirits by his congenial conversation. 
the picturesque white hair contrasting with the fine dark blue-grey eyes, and such a benevolent and peaceful expression. Periods of unconsciousness supervened, and the doctors warned the anxious watchers that he might thus pass away; but on the 29 th of June, after eleven hours of complete unconsciousness, the spirit seemed to return to give consolation to those left behind, for suddenly his eyes opened, and in a perfectly clear and distinct voice he spoke to his wife with wonderful words of loving farewell, and then added, "Wish our dear children good-bye for me; give my love to them all," and he repeated their names, remembering exactly who were away in their married homes and who were in the house, and then emphatically concluded with, "Remember, the same God, the same Saviour, the same heaven in which to meet again."

Almost the last words he heard on earth were those of the $23^{\text {rd Psalm; }}$ and when his wife came to "Though I walk through the valley of the shadow of death, I will fear no evil: for Thou art with me; Thy rod and Thy staff comfort me," she was almost startled by the vehemence with which he exclaimed, "It is so, it is so," and he spoke of the "support of the everlasting arms."

On Saturday, the Ist of July, the doctors announced that the precious patient was sinking; but it was all as he had often expressed the wish that it should be, his wife beside him, also his son Victor and his 
two youngest daughters, Geraldine and Augusta, when perfectly peacefully his "spirit passed to God who gave it." There are many names for death, and one is Life.

There was a "Memorial Service" in St. Luke's Church, Chelsea, conducted by the Dean of Westminster and the rector of the parish. Lovely flowers were sent from far and near, and the church was filled with relations and friends, including many old servants who had come long distances to show their respect to a beloved master; whilst Science and Art were fully represented by public bodies and institutions, and many distinguished men, including his friend, the veteran Sir Joseph Hooker.

He had served his country in his life, and so he did also in his death, for being thoroughly convinced that "cremation" is a duty we owe to our fellow-men as conducive to the public health, he left clearly-written directions that his body should be cremated at Woking, and his ashes afterwards laid, with the Church of England service, at the village of Stone in Buckinghamshire (where in 1858 his marriage had taken place), in his own words, " beside the church where our life together began."

Blessed are the pure in heart, for they shall see God. 



\section{APPENDIX I}

\section{NOTES ON THE MEDICAL ARRANGEMENTS OF THE BRITISH ARMY IN THE CRIMEA}

\section{(September I4 to December 12, 1854)}

WE landed in the Crimea on the 14th September 1854 . The Regiment (63rd) was then about 970 strong. The medical establishment consisted of a surgeon and three assistant surgeons, and hospital-sergeant and three or four orderlies. Two panniers contained all the medicines, instruments, and surgical appliances. These were carried by a pony, brought from Varna for the purpose. This was the only means of transport provided, except that a bell-tent for the hospital of each regiment was carried by the waggons attached to the headquarters of the division. Except for two nights, there were no other tents for a period of three weeks. The regimental medicine-chests, hospital bedding, and other stores were left on board ship, and were not landed during the time I remained in the Crimea.

The panniers were fitted up in England, and every regiment was furnished with similar ones. They contained a supply of medicines, etc., that might have lasted a healthy regiment two or three weeks, but a sickly one scarcely so many days. I believe they were only intended for ready use on the field or on the march, for which they were well adapted, but not to take the place of the regular medicine-chests.

There were ten stretchers, which had to be carried by the band in addition to their instruments, in consequence of which many were lost on the way. No means were provided for conveying sick on the march. Two of the ambulance waggons were 
landed, but I believe they were shipped again, as I saw or heard nothing of them again till some time after we reached Balaclava.

Just before we marched the surgeon procured, with great difficulty, and by mere chance, an araba waggon, which was of some assistance. On the second day's march we fell in with some commissariat waggons of another division that had missed their way, and we pressed them into our service; there were six or seven, mostly empty. These were barely sufficient for carrying our sick, and we lost them after the battle of Alma, and then were reduced to the original waggon.

At the end of every day's march those men who were unable to proceed were sent on board ship. During the march those who could not get on-and we had no means of carrying-were left on the way, with their arms, ammunition, etc. The prevalent diseases from which the men suffered were cholera and diarrhœa; the latter often lasted but a few hours, but quite disabled them from marching under the heavy weight they had to carry. If they could have been conveyed in waggons for a short time, most of them would have been well and able to walk again. The numbers sent on board ship during the march must have been very great, and as most of them were affected only temporarily, if they could have been brought on, the strength of the army would not have been so much diminished. We thus sent away twenty or thirty daily. Before we left the Alma we sent upwards of sixty at one time to the ships. We had great difficulty in getting these conveyed down to the sea. It was only by great exertions on the part of the surgeon that he procured some waggons from a commissariat officer, who afterwards said that he got into a scrape for lending them. If he had not done so, we must have left them all behind.

The men complained much of not having their knapsacks; the packs they had to carry, consisting of a pair of boots, etc., wrapped in the blanket, were most inconvenient.

A great number of wounded men and officers were on the field the morning after the battle of Alma, and many were not removed or attended to till quite late in the day.

I should think that if all the surgeons and assistant-surgeons 


\section{APPENDIX I}

of the regiments not engaged in action were employed, there must have been sufficient medical attendance.

The great difficulty seemed to be the want of transport. The araba waggons of the country were a miserable means of conveyance for sick and wounded; inconvenient to sit or lie in, jolting, and very slow.

The sailors rendered great service in carrying the wounded down to the beach, in hammocks slung on oars. A few ambulance waggons would have been an immense assistance, and saved very much suffering, as we afterwards found at Inkerman.

The French arrangements for carrying the sick and their field hospitals were far superior to ours.

When we had been about a fortnight before Sebastopol the ambulance waggons were landed. There were two attached to each division (an insufficient number). They were rather too heavy for the country, but did good service till about the middle of November, when the mules died. After then we had to depend on the commissariat waggons and the French mules to take our sick down to Balaclava. (The 9 th of December was the first day on which I saw the latter so employed.)

The number of men sent down was not dependent on the number of cases that required removal, but on the means of transport. The staff-surgeon of the division would say that so many men could be taken on such a day, and so we had to pick out the worst cases.

During the time we were on the heights before Sebastopol we had a marquee, also a number of bell-tents; these afforded very insufficient shelter, as it was impossible to keep the doors closed or the edge of the canvas close to the ground. The rain came through them. Though my tent was a new one, the rain always came through the side on which the wind blew. The bottom of the tents was covered with mud, nearly ankle-deep in some. The men had nothing to lie on or cover them but the blanket and great-coat ; these were in a very filthy and dilapidated condition, and generally wet through, as the men usually came to hospital directly after a night's work in the trenches, and there was no means of drying or cleaning them. The men lay on the 
ground as closely packed together as possible. In spite of the free ventilation, the smell in the tents was generally most disgusting. There was no attempt at cleanliness of any sort. The orderlies did their best, but they were quite insufficient in number, strength, or energy. Most of them either became sick or died, and we were obliged to obtain others, quite inexperienced or unfitted for the work.

The men in hospital were generally supplied with fresh meat, but very rarely with vegetables. The supply of provision to the men (of the 4th Division) up to the I6th of November was very regular, consisting of biscuit, fresh meat two or three times a week; salt pork and beef on the other days; green coffee; occasionally tea and rice; sugar and rum. After the 16 th the supply was very irregular, the meat almost always salt, and sometimes none issued for two days together; the biscuit was the only thing to depend upon, and that was wanting on one occasion. As the officers could obtain supplies from Balaclava, they did not feel this so much as the men. Fresh vegetables were served out once-a few onions and a small cabbage between half a dozen men. There was no insufficiency of lint, bandages, and surgical appliances, but of medicines I may say we never had an adequate supply - sometimes we were in total want of some of the most useful. We had to send down to Balaclava for them, and generally would get but half or quarter the quantity put on the requisition, and sometimes none at all.

The great causes of sickness at this period were overwork, insufficiency of diet, and exposure to weather without change of clothing; the men never took their clothes off, and were frequently wet through from one week's end to another. The overwork from which the men suffered was partly caused by a fallacy in the daily returns. At the morning inspection the surgeon sent in the number of men unfit for duty; the remainder were all supposed to be fit; but many were in the trenches or away on duty in the morning, and reported themselves sick when they came home, and others fell sick in the course of the day, so when the time came for going to the trenches in the evening, the number of able men was much less than was calculated on, and consequently the duty fell more heavily on them; for every 
man that fell sick after the morning report another had to suffer.

The regulations respecting sick officers who required removal from the camp were latterly very stringent, and, as they were carried out, often injurious. On the and December the surgeon of my regiment recommended me for a fortnight's leave to Balaclava; this order had to be countersigned by the StaffSurgeon of the Division, the Commanding Officer of the Regiment, the General of the Division, and the Adjutant-General at Headquarters. During this process it was probably lost, as it never came back to me. I have heard of several similar instances.

The state of the sick on board the transports from Balaclava to Scutari was very bad-crowded, lying on the bare deck, with only their old clothes and blankets, covered with vermin and filth. The orderlies were all weakly men or convalescents, and were by no means equal to the work. After they arrived at Scutari there was great delay in getting them into hospital.

When I visited the hospital at Scutari in the beginning of January, the wards were crowded but clean, the patients appeared comfortable, and the clothing, bedding, and diet looked good. Whether this was the work of Miss Nightingale and the Times Commissioner or of the Government officials, I cannot say.

Chloroform was always given in the severe operations in the $6_{3}$ rd, and invariably with good result.

The total number of deaths in the British Army were, according to the Adjutant-General, 25,000, and according to the Medical Department, I9,000. 


\section{APPENDIX II}

\section{HUNTERIAN LECTURES}

Delivered at the Royal College of Surgeons

\begin{tabular}{|c|c|c|}
\hline Date. & $\begin{array}{l}\text { Number } \\
\text { of } \\
\text { Lectures. }\end{array}$ & Subject. \\
\hline 1870 & 18 & $\begin{array}{l}\text { Comparative Anatomy ; introductory to the } \\
\text { Study of the Anatomy of the Class Mam- } \\
\text { malia. }\end{array}$ \\
\hline 1871 & 18 & $\begin{array}{l}\text { Comparative Anatomy; on the Characters, } \\
\text { Structure, Functions, and Modifications of } \\
\text { the Teeth and Allied Organs in the } \\
\text { Mammalia. }\end{array}$ \\
\hline 1872 & 18 & $\begin{array}{l}\text { Comparative Anatomy; on the Modifica- } \\
\text { tions of the Organs of Digestion in the } \\
\text { Vertebrata. }\end{array}$ \\
\hline 1873 & 18 & $\begin{array}{l}\text { Comparative Anatomy ; on the Osteology } \\
\text { and Dentition of Extinct Mammalia. }\end{array}$ \\
\hline 1876 & 9 & Relation of Extinct to Existing Mammalia. \\
\hline 1877 & 9 & Comparative Anatomy of Man. \\
\hline 1878 & 9 & Do. do. do. \\
\hline 1879 & 9 & Do. do. do. \\
\hline 1880 & 9 & Do. do. do. \\
\hline 1881 & 9 & $\begin{array}{l}\text { Anatomy, Physiology, and Zoology of the } \\
\text { Cetacea. }\end{array}$ \\
\hline 1882 & 9 & $\begin{array}{l}\text { Anatomy, Physiology, and Zoology of the } \\
\text { Edentata. }\end{array}$ \\
\hline 1883 & 9 & Anatomy of the Horse and its Allies. \\
\hline 1884 & 9 & Principal Types of the Human Species. \\
\hline
\end{tabular}




\section{APPENDIX III}

\section{LIST OF PUBLISHED WRITINGS}

COMPILED BY Mr. Victor A. FLOWER

Notes on the Dissection of a Species of Galago. Zool. Soc. Proc. xx. I852, pp. 73-75.

On a Case of Perforating Ulcer of the Esophagus, which caused Death by penetrating the Aorta (1853). Medico-Chirurgical Transactions, vol. xxxvi. p. 353 .

Encysted Coagulum in the Arachnoid Cavity (in Diseases of the Nervous System). Trans. Pathological Society, vol. vii. p. 6.

Fibrinous Coagulum, obstructing the Left Common Iliac Artery and causing Gangrene of the Leg. Trans. Pathological Society, vol. vii. p. 175 .

On a Cast showing a Rupture of the Ligamentum Patellæ, subsequent to Fracture of the Patella. Trans. Pathological Society, vol. vii. p. 315.

Cysto-Myeloid Tumour of the Upper Head of the Tibia (with Messrs. Shaw and Sibley). Trans. Pathological Society, vol. vii. p. 318.

On Extensive Osseous Deposit in the Dura Mater. Trans. Pathological Society, vol. viii. p. 26.

On an Epithelial Tumour in the Sheath of the Sciatic Nerve. Trans. Pathological Society, vol. ix. p. Ir.

On Acute Periostitis of the Tibia with Necrosis of the Entire Shaft of the Bone, following Strumous Disease of the Ankle-Joint. Trans. Pathological Society, vol. x. p. 2 I 4.

On Epithelial Cancer occurring in the Cicatrix of a Burn on the Arm. Trans. Pathological Society, vol. x. p. 253. 
On Colloid Cancer from the Calf of the Leg. Trans. Pathological Society, vol. x. p. 256.

The Importance of a Knowledge of the Elements of Practical Surgery to Naval and Military Officers. Journal of the Royal United Service Institution, vol. cxi. London, I 859.

On Sanguineous Cyst from the Shoulder. Trans. Pathological Society, vol. xi. p. 237.

On the Structure of the Gizzard of the Nicobar Pigeon and other Granivorous Birds. Zool. Soc. Proc. xxviii. 1860, pp. 330-334. Injuries of the Upper Extremity, in Holmes' System of Surgery. London, 1860.

On Dislocations of the Shoulder-Joint. Trans. Pathologica Society, London, vol. xii. $186 \mathrm{r}$.

Tabular Statement of the Specimens of Complete Dislocation of the Humerus preserved in the Anatomical Museums of London. Trans. Pathological Society, vol. xii. p. 189.

Diagrams of the Nerves of the Human Body. Folio, London, I861. Observations of the Posterior Lobes of the Cerebrum of the Quadrumana, with a Description of the Brain of a Galago. Roy. Soc. Proc. xi. 1860-1862, pp. 376-38r, 508 ; Phil. Trans. I 862, pp. I 85-201.

Notes on the Anatomy of Pithecia Monachus, Geoff. Zool. Soc. Proc. 1862, pp. 326-333.

Our Feet and their Coverings. A Review reprinted from the Medico-Chirurgical Review of July 1862 , London, 1862.

On the Brain of the Siamang (Hylobatus syndactylis, Raffles). Nat. Hist. Review, I863, pp. 279-287.

On the Brain of the Javan Loris (Stenops javenicus, Illig.) (1862). Zool. Soc. Trans. v. 1866, pp. I03-111.

A Supplement to the Catalogue of the Pathological Series in the Museum of the College of Surgeons. 1863.

Note on the Number of the Cervical Vertebræ in the Sirenia. Nat. Hist. Review, I 864, pp. 259-264.

On the Optic Lobes of the Brain of the Echidna. Zool. Soc. Proc. I 864, pp. 18-20.

On a Lesser Fin-Whale (Balænoptera rostrata, Fabr.) recently stranded on the Norfolk Coast. Zool. Soc. Proc. 1864, pp. $252-258$. 
On the Brain of the Red Howling Monkey (Mycetes seniculus, Linn.). Zool. Soc. Proc. 1864, pp. 335-338.

Notes on the Skeletons of Whales in the Principal Museums of Holland and Belgium, with descriptions of two species apparently new to Science (Sibbaldius schlegelii and Physalius latirostris). Zool. Soc. Proc. 1864, pp. 384-420.

On a New Species of Grampus (Orca meridionalis) from Tasmania. Zool. Soc. Proc. 1864, pp. 420-426.

On the Commissures of the Cerebral Hemispheres of the Marsupialia and Monotremata, as compared with those of the Placental Mammals. Phil. Trans. clv. I865, pp. 633-651 ; Roy. Soc. Proc. xiv. I865, pp. 7 I-74.

Reply to Professor Owen's Paper: On Zoological Names of Characteristic Parts and Homological Interpretations of their Modifications and Beginnings, especially in Reference to Connecting Fibres of the Brain. Roy. Soc. Proc. xiv. I 865 , pp. 134-1 39 .

Note on Pseudorca Meridionalis. Zool. Soc. Proc. I 865, pp. $470-471$.

On Physalius Sibbaldii, Gray. Zool. Soc. Proc. I 865, pp. 472-474.

Observations upon a Fin. Whale (Physalius antiquorum, Gray) recently stranded in Pevensey Bay. Zool. Soc. Proc. 1865, pp. 699-705.

On the Gular Pouch of the Great Bustard (Otis tarda, Linn.). Zool. Soc. Proc. 1865 , pp. 747, 748.

Sur le Bassin et le Fémur d'une Balénoptère. Bruxelles, Acad. Sci. Bull. xxi.' 1866, pp. I 3 I, 132.

Recent Memoirs of the Cetacea, by Professors Eschricht, Reinhardt, and Lilljeborg (Ray Society). Folio, London, 1866.

On the Development and Succession of the Teeth in the Marsupialia. Phil. Trans. clvii. 1867, pp. 63I-642; Roy. Soc. Proc. xv. 1867, pp. 464-468; Ann. Mag. Nat. Hist. xx. 1867, pp. 1 29-1 33 .

Account of the Dissection of a Bushwoman. Journal of Anatomy and Physiology, vol. i. pp. 189-208 (with Dr. James Murie), London, 1867.

Notes on the Visceral Anatomy of Hymoschus Aquaticus. Zool. Soc. Proc. 1867, pp. 954-960. 
On the Homologies and Notation of the Teeth of Mammalia. Brit. Assoc. Rep. xxxviii. 1868 (Sect.), pp. I I 5, I16 ; Journal of Anatomy, cxi. 1869, pp. 262-278.

On the Affinities and Probable Habits of the Extinct Australian Marsupial, Thylacoleo Carnifex, Owen. Geol. Soc. Quart. Journ. xxiv. I868, pp. 307-319; Phil. Mag. xxxvi. I868, p. 73.

On the Probable Identity of the Fin-Whales, described as Balænoptera Carolinæ, Malm, and Physalius Sibbaldii, Gray. Zool. Soc. Proc. 1 868, pp. 187-189.

On the Development and Succession of the Teeth in the Armadillos (Dasypodidæ). Zool. Soc. Proc. 1868, pp. 378-380.

On the Value of the Characters of the Base of the Cranium in the Classification of the Order Carnivora, and on the Systematic Position of Bassaris and other Disputed Forms. Zool. Soc. Proc. I 869, pp. 4-37.

Note on the Substance ejected from the Stomach of a Hornbill (Buceros corrugatus). Zool. Soc. Proc. I869, p. 150.

On the Anatomy of the Proteles, Proteles Cristatus, Sparrman. Zool. Soc. Proc. I 869, pp. 474-496.

Notes on Four Specimens of the Common Fin-Whale (Physalius antiquorum, Gray; Balænoptera musculus, Auct.) stranded on the South Coast of England. Zool. Soc. Proc. 1869, pp. 604610.

Description of the Skeleton of Inia Geoffrensis and of the Skull of Pontoporia Blainvillei, with Remarks on the Systematic Position of these Animals in the Order Cetacea (1866). Zool. Soc. Trans. vi. 1869, pp. 87-1 I6.

On the Osteology of the Cachalot or Sperm-whale (Physeter macrocephalus) (1867). Zool. Soc. Trans. vi. 1869, pp. 309-372.

On the Connection of the Hyoid Arch with the Cranium. Brit. Assoc. Rep. xl. 1870 (Sect.), pp. 1 36, 137.

On the Correspondence between the Parts composing the Shoulder and the Pelvic Girdle of the Mammalia. Journal of Anatomy, iv. 1870 , pp. $239-245$.

Additional Note on a Specimen of the Common Fin-Whale (Physalius antiquorum, Gray; Balænoptera musculus, Auct.) stranded in Langston Harbour, November 1869. Zool. Soc. Proc. 1870, pp. 330,331 . 
On the Anatomy of Elurus Fulgens, Fr. Cuv. Zool. Soc. Proc. I 870, pp. 752-769.

An Introduction to the Osteology of the Mammalia : being the Substance of the Course of Lectures delivered at the Royal College of Surgeons of England in 1870. London, Ist Edition (Globe 8vo) 1870; 2nd Edition (Crown 8vo) 1876; 3rd Edition (with Hans Gadow), 1885.

Introductory Lecture to the Course of Comparative Anatomy, delivered at the Royal College of Surgeons of England. Medical Times and Gazette, 1870 ; reprinted, 8vo, London, 1870 ; reprinted in Essays on Museums, 1898.

The New Natural History Museum. Nature, May 26, 1870.

On the Composition of the Carpus of the Dog. Brit. Assoc. Rep. xli. 1871 (Sect.), p. I 38 ; Journal of Anatomy, vi. 1872, pp. 62-64.

Burmeister's Fauna Argentina. Nature, February 9, I87 I.

On the First or Milk-Dentition of the Mammalia. Odontol. Soc. Trans. cxi. I87 I, pp. 2 I1-232. British Medical Journal, 1871.

On the Skeleton of the Australian Cassowary (Casuarius australis). Zool. Soc. Proc. I 87 I, pp. 32-35.

On the Occurrence of the Ringed or Marble Seal (Phoca hispida) on the Coast of Norfolk, with Remarks on the Synonymy of the Species. Zool. Soc. Proc. 1871, pp. 506-512.

On a Subfossil Whale (Eschrichtius robustus) discovered in Cornwall. Ann. Mag. Nat. Hist. ix. I872, pp. 440-442.

On the Arrangement and Nomenclature of the Lobes of the Liver in Mammalia. Brit. Assoc. Rep. xlii. 1872 (Sect.), pp. I 50, I 5 I ; Nature, vi. I872, pp. 346-365.

On the Bones of a Whale found at Pentuan, Cornwall. Geol. Soc. Trans. 1872 (October).

On the Ziphioid Whales. Nature, v. 1872, pp. 103-106.

Note on the Anatomy of the Two-Spotted Paradoxure (Nandinia binotata). Zool. Soc. Proc. 1872, pp. 683, 684.

Description of the Skeleton of the Chinese White Dolphin (Delphinus sinensis, Osbeck) (1869). Zool. Soc. Trans. vii. 1872, pp. I 5 I160.

Anatomy of the Digestive Organs of the Mammalia. Medical Times and Gazette, 1873. 
Note on the Carpus of the Sloths. Journal of Anatomy, vii. I 873 , pp. $255,256$.

The Pay of Scientific Men. Nature, July 24, 1873.

Fossil Sirenia. Nature, November 6, 1873.

On Palæontological Evidence of Gradual Modification of Animal Forms. Roy. Inst. Proc. vii. 1873, pp. 94-104; reprinted in Essays on Museums, 1898.

On a Newly Discovered Extinct Mammal from Patagonia (Homalodontotherium cunninghami). Roy. Soc. Proc. xxi. 1873, p. 383 ; Phil. Trans. clxiv. I874, pp. I 73-182.

On Risso's Dolphin (Grampus griseus, Cuv.) (1871). Zool. Soc. Trans. viii. I 873 , pp. I-2 I.

On the Recent Ziphioid Whales, with a Description of the Skeleton of Berardius Arnuschi, 1871. Zool. Soc. Trans. viii. 1873, pp. 203-234.

Notes of Experiences in Egypt. 8vo, London, 1874.

Description of the Skull of a Species of Helitherium (H. canhami) from the Red Crag of Suffolk (1873). Geol. Soc. Quart. Journ. xxx. 1874 , pp. I-7.

On the Structure and Affinities of the Musk Deer (Moschus moschiferus, Linn.). Zool. Soc. Proc. I875, pp. I59-190.

Elephants. A Lecture delivered at the Zoological Society's Gardens, Regent's Park. Nature, June ro, 1875.

Description of the Skull of a Species of Xiphodon, Cuvier. Zool. Soc. Proc. 1876, pp. 3-7.

The Uintatherium. Nature, March 23, 1876.

On some Cranial and Dental Characters of the Existing Species of Rhinoceroses. Zool. Soc. Proc. 1876, pp. 443-457.

On the Relation of the Extinct to Existing Mammalia. Nature, February 17 to May 4, 1876.

Remarks on Dr. von Haast's Communication on Ziphius Novæzælandiæ. Zool. Soc. Proc. 1876, pp. $477,478$.

Remarks upon Dr. von Haast's Communication on Mesoplodon Floweri. Zool. Soc. Proc. 1876, pp. 485, 486.

Extinct Lemurina. Ann. Mag. Nat. Hist. xvii. 1876, pp. 323-328.

Museum Specimens for Teaching Purposes (1876). Nature, xv. I 877, pp. I 44-1 46, I 84-186, 204-206. 


\section{APPENDIX III}

Note on the Occurrence of the Remains of Hyænarctos in the Red Crag of Suffolk. Geol. Soc. Quart. Journ. xxxiii. 1877, pp. 534-536.

Notes on Eskimo Skulls. Journ. Anth. Inst. vi. p. 539.

A Century's Progress in Zoological Knowledge (Opening Address to the Zoological and Botanical Section of the British Association, Dublin, August 1878). Brit. Assoc. Rep. I878, pp. 549-558; Nature, xviii. 1878, pp. 419-423; Revue Scientif. xv. 1879, pp. 496-502.

Methods and Results of Measurements of the Capacity of Human Crania. Brit. Assoc. Rep. 1878, pp. 581 , 582 ; Nature, xviii. I 878 , pp. 480,48 I.

On the Skull of a Rhinoceros (R. lasiotis, Scl. .) from India. Zool. Soc. Proc. I 878 , pp. 634-636.

The Extinct Animals of North America (1876). Roy. Inst. Proc. viii. I879, pp. I03-125; Popular Science Review, xv. 1876, pp. 276-298; Revue Scientif. xi. I 876, pp. 467-477.

A Further Contribution to the Knowledge of Ziphioid Whales (Genus Mesoplodon) (1877). Zool. Soc. Trans. x. 1879, pp. 4 I 5-437.

The Native Races of the Pacific Ocean (1878). Roy. Instit. Proc. viii. I879, pp. 602-652 ; Journ. Anth. Inst. vol. viii. p. 96.

Seals and Cetaceans. Transit of Venus Expeditions, 1874-1875. Collections from Kerguelen Island. Phil. Trans. clxviii. (extra vol.), I 879, pp. 95-100.

On the Common Dolphin (Delphinus delphis, Linn.). Zool. Soc. Proc. 1879 , pp. 382-384.

Remarks on the Skull of a Beluga or White Whale. Zool. Soc. Proc. I 879, pp. 667-669.

On the Cæcum of the Red Wolf (Canis jubatus, Desm.). Zool. Soc. Proc. I 879, pp. 766, 767.

Illustrations of the Mode of preserving the Dead in Darnley Island and in South Australia. Anthropol. Instit. Journ. 1879, pp. 389-394.

On the Scapular Index as a Race Character in Man. Journ. Anat. Physiol. xiv. I 879 (I 880), pp. I 3-I7 (with Dr. J. G. Garson).

Catalogue of Specimens illustrating the Osteology and Dentition of Vertebrated Animals, Recent and Extinct, contained in the 
Museum of the Royal College of Surgeons of England. Part I. Man, 1879; Part II. Mammalia other than Man (with Dr. J. G. Garson), 1884 .

The Comparative Anatomy of Man (Abstract of Lectures). Nature, xx. 1879, pp. 222-225, 244-246, 267-269; xxii. I 880, pp. 59-6I, 78-80, 97-100 ; British Medical Journal, I879-1880.

On the Osteology and Affinities of the Natives of the Andaman Islands (1879). Anthropol. Instit. Journ. ix. 1880, pp. I08135.

Note on the Specimens of Abnormal Dentition in the Museum of the Royal College of Surgeons (1879). Odontol. Soc. Trans. xii. I 880 , pp. $32-47$.

The Races of Men. A Lecture delivered in the City Hall, Glasgow, November 28, 1878. London (1879).

The Aborigines of Tasmania, an Extinct Race. A Lecture delivered in the Hulme Town Hall, Manchester, November $30,1878$. London (1879).

A Cranium of a Native of one of the Fiji Islands, February I I, I 879. Journ. Anth. Inst. vol. ix. p. 2.

(Remarks on a Skull of Rhinoceros Sumatrensis from Borneo). Zool. Soc. Proc. I880, pp. 69, 70.

On the Bush Dog (Icticyon venaticus, Lund.). Zool. Soc. Proc. I880, pp. 70-76.

On the Stature of the Andamanese. Anth. Inst. Journ. vol. x. p. I 24.

On the Cranial Characteristics of the Natives of the Fiji Islands (1880). Anthropol. Instit. Journ. x. I 88 I, pp. I 53-175.

Report on Bones found in a Roman Villa at Morton, near Brading, in April 1881. April 26, 1881, Anth. Inst. Journ. vol. xi. pp. I 16,117 .

The Study and Progress of Anthropology. (Address to the Anthrop. Department of the Biol. Sect. of the Brit. Assoc. at York, September I88I). Brit. Assoc. Rep. I881, pp. 682-689; Nature, xxiv. 1881, pp. 436-439; Anthrop. Inst. Journ. vol. xi. p. 184 et seq.

On the Elephant Seal (Macrorhinus leoninus, Linn.). Zool. Soc. Proc. I 88 I, pp. I 45-I62. 
The Museum of the Royal College of Surgeons of England. Address read at International Medical Congress, London, I88I ; reprinted in Essays on Museums, I 898.

Notes on the Habits of the Manatee. Zool. Soc. Proc. I 881 , pp. 453-456.

Fashion in Deformity as illustrated in the Customs of Barbarous and Civilised Races. Nature Series, crown 8vo, London, I $88 \mathrm{I}$.

On a Collection of Monumental Heads and Artificially Deformed Crania from the Island of Mallicollo, in the New Hebrides (188 I). Anthropol. Instit. Journ. xi. I 88I, pp. 75-8I.

The Anatomy of the Cetacea and Edentata. British Medical Journal, I 881-1882.

On the Mutual Affinities of the Animals composing the Order Edentata. Zool. Soc. Proc. I 882, pp. 358-367.

On the Cranium of a New Species of Hyperoodon from the Australian Seas (H. planifrons). Zool. Soc. Proc. 1882, pp. 392-396.

(Remarks on the Skull of a Young Chimpanzee). Zool. Soc. Proc. 1882, pp. 634-636.

Professor Rolleston. Obituary Notice in Proceedings of the Royal Society, vol. xxxiii. 1882 ; reprinted, with alterations, in Essays on Museums, 1898.

On the Whales of the Genus Hyperoodon. Zool. Soc. Proc. I 882, pp. 722-726.

On the Death of Charles Darwin. Anth. Inst. Journ. vol. xii. p. 229.

On the Arrangements of the Orders and Families of Existing Mammalia. Zool. Soc. Proc. I883, pp. I78-I 86.

On the Characters and Divisions of the Family Delphinidæ. Zool. Soc. Proc. $188_{3}$, pp. $466-5$ I 3 .

On a Specimen of Rudolph's Rorqual (Balænoptera borealis, Lessin) lately taken on the Essex Coast. Zool. Soc. Proc. I 883 , pp. 5 I 3-5 17.

On Whales, Past and Present, and their Probable Origin ( 1883 ). Roy. Inst. Proc. x. 1884 , pp. 360-376; Nature, xxviii. I883, pp. 199-202, 226-230.

On the External Characters of two Species of British Dolphins (Delphinus delphis, Linn.; and D. tursio, Fabr.) (1879). Zool. Soc. Trans. xi. 1885 , pp. I-5. 
Recent Advances in Natural Science in their Relation to the Christian Faith. A Paper read at the Reading Church Congress, October I 883. 8vo, London, I883.

On a Deformed Skull of a Chimpanzee, November 13, 1883. Anth. Inst. Journ. xiii. p. 276.

Die Wale in Vergangenheit und Gegenwart und ihr wahrscheinlicher Ursprung. Kosmos (Vetter), 7 Jahag, 5 Hgr. 13 Bd. pp. 358-368; 7 Hgr. pp. 525-532.

Evolution of the Cetacea. Nature, dccxxxviii. p. I 70.

Notes on the Names of two Genera of Delphinidæ. Zool. Soc. Proc. London, 1884, cxi. pp. 417, 418.

Notes on the Dentition of a Young Capybara (Hydrochœrus capybara). Zool. Soc. Proc. London, I 884, xi. pp. $252,253$.

Additional Observations on the Osteology of the Natives of the Andaman Islands, May 13, 1884. Anth. Inst. Journ. vol. xiv. pp. I 1 5-1 20.

Remarks upon Four Skulls of the Bottle-nose Whale (Hyperoodon rostratus). Zool. Soc. Proc. London, r884, xi. p. 206.

On the Size of Teeth as a Character of Race. Anth. Inst. Journ. vol. xiv. pp. I83-187.

The Classification of the Varieties of the Human Species. Anth. Inst. Journ. vol. xiv. pp. 378-395, I885 ; Náture, vol. xxxi., No. 799, pp. 364-367.

List of the Specimens of Cetacea in the Zoological Department of the British Museum. London, I885, 8vo.

The Wings of Birds. A Lecture delivered February I9, I 886. Royal Inst. Proc. ; Nature, vol xxxiv., No. 870, pp. 204, 205.

On a Nicobarese Skull, May I I, I886. Anth. Inst. Journ. vol. xvi. pp. 1 47-1 49.

On an Exhibition of Ethnological Casts, November 9, r886. Anth. Inst. Journ. vol. xvi. pp. 24 I-242.

Obituary Notice of George Busk, F.R.S. Anth. Inst. Journ. vol. xvi. p. 403.

On the Pygmy Hippopotamus of Liberia (Hippopotamus liberiensis, Morton), and its Claims to Distinct Generic Rank. Zool. Soc. Proc. London, I887, pp. 6I2-514, iv.

Description of two Skeletons of Akkas : a Pygmy Race from Central Africa, February 1 4, I 888. Anth. Inst. Journ. vol. xviii. pp. 3-19. 
Les Musées d'Histoire Naturelle. Revue Scientif. t. xliv. No. I3, pp. 385-395.

Museum Organisation. Presidential Address Brit. Assoc., Brit. Assoc. Report, I899; Nature, vol. xl. No. 1037, pp. 463-469; reprinted in Essays on Museums, I 898.

L'Indirizzo e lo Scopo di un Museo di Storia Naturale. Tradotto da C. Doria e D. Vinciguerra. Genova, I 890.

Suggestions for the Formation and Arrangement of a Museum of Natural History in Connection with a Public School. Nature, vol. xli. No. 1052, pp. 177-178.

Who discovered the Teeth of Ornithorhynchus? Nature, vol, xli. No. 1046, p. 3 I ; No. I05 I, pp. I 5 I, I 52.

Zoological Society of London. Presidential Address at the General Meeting of the Society held in the Society's Gardens, Regent's Park, in celebration of the Fiftieth Anniversary of Her Majesty's Reign. London, 1887.

Eulogium on Charles Darwin. Linn. Soc. Proc. London, November I 887 , June I888, pp. 67-70.

Einleitung in die Osteologie der Säugethiere. Nach der 3. unter Mitwirkung von Dr. Gadow durchgesehenen Orig. Ausg. 8vo, Leipzig, I 888.

Horns and Antlers. A Lecture delivered December I3, I887. Trans. Middlesex Natural History Society.

The Pygmy Races of Men. A Lecture delivered April 13, 1888 Royal Inst. Proc., Anth. Inst. Journ. vol. xviii. p. 73.

The Aims and Prospects of the Study of Anthropology An Address. Anth. Inst. Journ. vol. xviii. pp. 488-50 I ; Nature, vol. xxix. No. 744, pp. 319-322.

Remarks upon the Skin of the Face of a Male African Rhinoceros with a Third Horn. Zool. Soc. Proc. London, I889, iv. pp. $448,449$.

On an Artificially Deformed Skull from Mallicollo, March 12, I889. Journ. Anth. Inst, vol. xix. pp. 52-54.

School Museums. Nature, December 26, 1889; reprinted in Essays on Museums, I898.

The Natural History Museum, Cromwell Road, and some Recent Additions thereto. Trans. Middlesex Natural History Society, I889. 
On two Skulls from a Cave in Jamaica, May II, 1890. Anth. Inst. Journ. vol. xx. pp. I I O-I I 2.

On a Fetish or Ula from Lake Nyassa, June I0, 1890 . Anth. Inst. Journ. vol. xx. pp. 225.

The Booth Museum at Brighton. The Zoologist, December 1900; reprinted in Essays on Museums, I 898.

The Horse, a Study in Natural History (Modern Science Series). 8vo, London, I891; New York, I892.

The Oxford University Museum. Nature, vol. xliv. No. I I48, pp. 6 I9-62 I.

An Introduction to the Study of Mammals, Living and Extinct (with Richard Lydekker). 8vo, London, I891.

Modern Museums. Presidential Address at the 1893 Meeting of the Museums' Association. Report of the Museums' Association, 1893 ; reprinted in Essays on Museums, 1898.

Richard Owen. Obituary Notice in Proceedings of the Royal Society, vol. lv. 1894 ; reprinted, with alterations, in Essays on Museums, 1898.

Sir Victor Brooke: His Researches in Natural History. In Mr. Leslie Stephen's Life of Sir Victor Brooke, 8vo, London, I 894.

Seals. A Lecture delivered at the Royal Institution. Royal Inst. Proc. vol. xiv. I893-1895.

The Study of Anthropology. Presidential Address, Anthropological Section, Oxford. Brit. Assoc. Report, I 894.

On a Collection to illustrate the General Characters of the Eggs of Birds. The Ibis, July I 894.

Whales and Whale Fisheries. A Lecture delivered at the Royal Colonial Institute, 8th January I 895.

Reminiscences of Professor Huxley. The North American Review, September 1895 ; reprinted in Essays on Museums, 1898.

Van Beneden. Obituary Notice from Proceedings of the Royal Society, vol. Ivii.

George Edward Dobson. Obituary Notice from Proceedings of the Royal Society, vol. lix.

Natural History as a Vocation. Chambers's Journal, vol. xiv. I 897 ; reprinted in Essays on Museums, 1898.

Essays on Museums and other Subjects connected with Natural History. 8vo, London, 1898. 


\section{APPENDIX III}

Articles in "Encyclopedia Britannica" (9Th Edition)

$\begin{array}{llll}\text { Horse. } & \text { Mandrill. } & \text { Otter. } & \text { Swine. } \\ \text { Kangaroo. } & \text { Megatherium. } & \text { Peccary. } & \text { Tapir. } \\ \text { Lemming. } & \text { Mink. } & \text { Platypus. } & \text { Tiger. } \\ \text { Lemur. } & \text { Munt-jak. } & \text { Porpoise. } & \text { Walrus. } \\ \text { Leopard. } & \text { Musk deer. } & \text { Puma. } & \text { Weasel. } \\ \text { Lion. } & \text { Musk ox. } & \text { Quagga. } & \text { Whale. } \\ \text { Llama. } & \text { Musk rat. } & \text { Rhinoceros. } & \text { Wolf. } \\ \text { Mammalia. } & \text { Narwhal. } & \text { Seal. } & \text { Wombat. } \\ \text { Mammoth. } & \text { Nilghai. } & \text { Sheep. } & \text { Yak. } \\ \text { Manatee. } & \text { Ocellot. } & \text { Sloth. } & \text { Zebra. }\end{array}$




\section{APPENDIX IV}

Copy of inscription on the Memorial Tablet placed in the Meeting Room of the Zoological Society of London, by order of the Council, in memory of the late Sir William Flower, K.C.B. President of the Society :-

This Tablet is erected

by the Zoological Society of London

to the Memory of

Sir WILLIAM H. FLOWER, K.C.B., LL.D., F.R.S., its late President, in recognition of his great eminence as a Zoologist, and in gratitude for the valuable services rendered to the Society throughout the 20 years during which he occupied the Presidential Chair.

I 879-1 899. 


\section{INDEX}

Acton, Lord, 2 I 8

Agassiz, Louis, 79

Airy, Rev. W., Vicar of Keysoe, 43

Akkas, pigmy tribes of Central Africa, 198, 200, 201

Aldworth, visit to Lord Tennyson at, 204

Alma, battle of, 22

Alnwick Castle, visits to, 2 I I, 228

Amory, Dr., 3

Andaman islanders, cranial characters, I I I

Anthropological Institute, I 92, 197

Anthropology, I 90 et seg.

Anthropometric Laboratory at South Kensington, I97

Anthropometry, I96

Apes, brains of, 65 ; vocal organs of, II 9

Argyll, Duke of, correspondence with Sir William Flower, I07-1 22, 127 ; Trustee of British Museum, 123 ; guest with Sir William at Aldworth, 204-209 ; reminiscences of Duke of Wellington, 207

Armstrong, Lord, 2 I I

Army Medical Department. See Appendix I.

Ashmolean Museum, 196

Asquith, Right Hon. H. H., 197

Athenaum on Sir William Flower's services to anthropology, 20I, 202

Australia, native dogs, I 10

Avebury, Lord, visit to, 228

Aves, in Natural History Museum, I 42, I 43

Baden - Powell, General Robert Stephenson Smyth, C. B., 4I
Baden-Powell, Rev. Professor, 4I ; officiates at marriage of Sir William H. Flower, 43 ; death, 45 ; obituary notice, 47

Baden-Powell, Sir George Smyth, M.P., 4 I

Bailey's Magazine, 2 I 4, 2 I 5

Baillie, Lady Frances, 89, 90

Balaclava, battle of, 25. See Appendix I.

Balfour, Professor F. M., on elasmoid fishes, II 7

Balfour, Henry, 196

Balfour, Mr., Secretary of the Royal College of Surgeons, his recollections of Lincoln's Inn Fields, 76, 77

Balmoral Castle, visit to, 2 I 6

Banks, Sir Joseph, I 34

Barton, J. Kingston, 229, 240

Basque whale fishery, I73

Battenburg, Prince Henry of, 217

Beaconsfield, Earl of, 133, I93

"Bearing reins" on horses, protest against, 215

Bell, F. Jeffrey, 148

Beneden, Professor van, 103,172

Benson, Most Rev. E. W., Archbishop of Canterbury, I24, I50, I $55 n$.

Bentham, George, I $24 n$.

Berthillon, M., anthropometric system, 197

Bethnal Green, lecture to boys at, $\mathbf{I} 59$

Biddulph, Colonel, of Rathrobin, 80 ; visits to, 229, 234

Biddulph, Mrs. (Sir William Flower's second daughter), writes of younger days with her father, 80 ; holiday in Switzerland, 160 
Bille, M. de, Danish Minister, 232

Blumenbach, Johann $F$., his five races of man, 197

Blunt, Rev, Gerald, $24 \mathrm{I}$

Boehm, Sir Edgar, 155

Bond, Sir Edward, I 24, I25; letter to Sir William Flower, I 26

Bonney, King George of, 79

Booth collection of birds at Brighton, $145,146,187 n, 213$

Botanical Department in Natural History Museum, 134, 147

Boulenger, G. A., F.R.S., I38, 148

Bradley, Very Rev. George Granville, Dean of Westminster, 243

Breslin, Dr., and soldiers' stocks, I 5

Brighton, opening of Booth Museum, 146

British Association, meeting at Cambridge (1862), 65; Sir William Flower President of, at Newcastle (1889), I80, 2II; presses the claims of Anthropology at I88 I and 1894 meetings, 192, 196

Brock, Thomas, R.A., I 88

Brooke, Sir Victor, Life of, by Leslie Stephen, $219 n$.

Browning, Robert, 79

Bruce, Lady Augusta. See Stanley, Lady Augusta

Buckingham Palace, garden parties at, 216

Buckland, Frank, 7I; on study of taxidermy, 72 ; tribute to $\mathrm{Sir}$ William Flower, I 7 I

Bullen, Frank T., 240

Burns, John, M.P., 204

Burton Constable, sperm whale at, I 7 I

Busk, Professor George, at University College, 7; joint translator of Kölliker with Professor Huxley, 85

Cambridge University, Sir William Flower an LL. D. of, 224

Canterbury, Archbishops of, I 24, I 50, I 55 n., I 88, 203

Carpenter, Dr. W. B., I 24 n.

Carruthers, William, F.R.S., 147

Cawdor, Earl, visit to, 228

Cecil, Lord Eustace, 24 I $n$.

Cetacea, development of, III ; Sir
William Flower an authority on, 167 ; display of, in Natural History Museum, I 35 n., I 48, 230. See also Whales

Chamberlain, Right Hon. Joseph, 158 Chambers, Alberta Maitland. See Flower, Mrs. Arthur

Chambers, Dr. Thomas King, 213

Chelsea Industrial Exhibition, opening of, $16 \mathrm{I}$

Childers, Right Hon. Hugh C. E., $125,126,158$

Chillingham, visits to, 212,228

Chloroform, use of, at the Crimea, 29. See Appendix I.

Church, Rev. R. W., Dean of St. Paul's, 9I

Church Congress (1883), Sir William delivers address at, 93

Civil Service dinner, speech at, 2 I 2

Clark, J. Willis, Registrary of Cambridge University, $52 \mathrm{n}$, 129 , 166 ; on reforms in Hunterian Museum, 73

"Club, The," 218.

Cobbett, William, 92

Coleridge, Lord, 218

Conroy, Sir John, Bart., $93 n$.

Constable, Sir Clifford, I 7 I

Cornwall, holiday in, 2 Io

Craniology, 107-I 10, I9I

Crimean War, 16 et seq. See App. I.

Cromer, Lord, 236

Crowther, W. L., of Hobart Town, presents skeletons of whales to Hunterian Museum, 167

Cruise of the "Cachalot," 1 74, 240

Cuvier, 176 ; his races of man, 197

Dartmoor, summer residence at, 80

Darwin, Charles, $49,63 n$., 64,67 , 79, I34; meeting with Dean Stanley, 87 ; letter from Huxley, IOI ; statue of, in Natural History Museum, 155

D'Aumale, Duc, 218

Davey, Lord, 2 i 8

Davidson, Most Rev. Randall, Archbishop of Canterbury, I 51 , 188, 203

Davies, Rev. Llewelyn, 9I

Davis, Barnard, anthropological collection, 75 , 19 I 
Descent, law of, 95

Diary, Sir William Flower's, extracts from, in the Crimea, 16.24

Dillon, Viscount, expresses appreciation of services of Sir William Flower by Trustees of Natural History Museum, 225

Dingo, Australian dog, 1 10

Dohrn, Dr., of Marine Laboratory at Naples, 163

Doran, Dr. Alban, Assistant in Hunterian Museum, 57,58

Drummond, Mrs., of Megginch, 89

Duff, Right Hon. Sir Mountstuart E. Grant, 218

Dufferin, Marquis of, 218

Durham University, Sir William Flower receives degree of D.C.L., 2 I 1

Edgbaston, school, at, 5

Edinburgh University, Sir William Flower an LL.D. of, 224

Edward VII., King, interest in Natural History Museum, I23, 231 ; at unveiling of Darwin's statue, I55 ; letter to Sir William Flower, 234

Egypt, visit to, 82

Elgin, 7 th Earl of, 85

Emin Pasha, 144, I98; letter from, I 99, 200

Erichsen, Sir John, 136

Eschricht, Professor, I 76

Etheridge, Robert, F.G.S., 12 I

Ethnological Museum formed at Cam. bridge, 196

Ethnological Society, 192

Evans, Arthur, 196

Evolution, Sir William Flower's contribution to the understanding of, 64-68; address on, at Church Congress, 93-99; structure of whales in reference to, 161

Fagan, Charles E., Secretary of Natural History Museum, 204,

233 ; letters to, $219-223$

Farrar, Canon, 90

Felixstowe, summer residence at, 80

"First aid" in the seventies, 39

Fishes, electric organs of, I 2 I

Fishmongers' Company assists in estab- lishing Marine Laboratory at Plymouth, 164

Fletcher, L., F.R.S., 127, $140 n$.

Flower, Richard, of Marden Hill, Hertfordshire (Sir William's grandfather), I ; migrates to America, 91, 92

Flower, Edward Fordham (Sir William's father), his early life and marriage, $I$; settles at Stratford-on-Avon, I ; changes to London, I, 2 ; letter to, from Sebastopol, 31 ; urges his son to accept Curatorship of Hunterian Museum, 50 ; opposition to bearing reins for horses, 2 I 5

Flower, Celina (Sir William's mother), 2 ; letters to, 6, 7, 8, 12, 24, $26,27,29,36$, IOI, 102, I 7 I

Flower, Richard (Sir William's eldest brother), 2

Flower, Charles Edward (Sir William's brother), founder of Shakespeare Memorial, 2, 82

Flower, Edgar (Sir William's youngest brother), 2 ; letter to, from Sebastopol, 25

Flower, Sir William Henry, birth of, I ; parents, I ; brothers, 2 ; early life, 2 ; devotion to natural history, 3 ; first museum and collections, 3 ; delicate health of, 5 ; schooldays, at Edgbaston and Worksop, 5 , 6; enters University College, London, 6; walking tours, 9, I0; reads his first paper, before Zoological Society of London, Io; appointed House Surgeon to Middlesex Hospital, I0; passes examination for membership of Royal College of Surgeons, 10 ; undertakes curatorship of Middlesex Hospital Museum, 10; joins Army Medical Staff, 12; Assistant Surgeon at Templemore, I4 ; joins 63 rd Regiment and sails for the Crimea, 15.17 ; extracts from his diary, 17-24; letters from the Crimea, 24-34; invalided home from Crimea, 35 ; decorated for services, 37 ; returns to civil life, 37 ; takes diploma of F.R.C.S., 37 ; appointed Assistant-Surgeon 
Flower, Sir William, contd.and Lecturer on Comparative Anatomy in Middlesex Hospital, 37 ; meets his future wife, 40 ; his marriage, 43 ; children, 45 , 47, 74; completion and publication of Diagrams of the Nerves of the Human Body, 45; retires from professional life as a surgeon, 47; appreciation by Governors of Middlesex Hospital, 47,48 ; appointed Conservator of Hunterian Museum, 51 ; at meeting of British Association (1862), 66; home life at Lincoln's Inn Fields, 74 et seq.; recreations, 77 ; holidays at home and abroad, 80,81 ; ill-health, 82 ; visit to Egypt, 82 ; friendship with Dean Stanley, 84-91 ; present at death of Dean Stanley, 90 ; religious disposition, 9I ; address on evolution at Church Congress (1883), 93. 99 ; elected a Fellow of Royal Society, IOI ; appointed Hunterian Professor, IOI; inaugural lecture, 103 ; subjects of lectures, 105, 106; elected President of Royal Zoological Society, I06; correspondence with Duke of Argyll, 107.122; appointed Director of Natural History Museum, 125 ; Times on appointment, 128; his memoir of Sir Richard Owen, 133 ; removes to Stanhope Gardens, I36; resigns Curatorship of the Hunterian Museum, I36 ; opens the Booth Museum at Brighton, 146 ; Keeper of Zoology, I47, I84; at unveiling of Darwin's statue, 155; elected Trustee of the Hunterian Museum, 1 58 ; distributes school prizes in Birmingham Town Hall, 159 ; lectures at Bethnal Green and Wellington College, I59; lectures at Royal and London Institutions, etc., 158-16I ; holiday in Switzerland, 160; honour of C.B. conferred, 163 ; honours and degrees, $163,224,231$; opens Marine Biological Laboratory at Plymouth, I63-I65;
Flower, Sir William, contd. President of British Association (1889), 180; visits Tennyson at Aldworth, 204-209; later days at Natural History Museum, 2 10; made D.C.L. of Durham University, 2II; visits to Duke of Northumberland and Earl of Tankerville, 211, 212, 228; lectures at Royal Institution, 212 ; at Civil Service dinner, 212; created K.C.B., 215 ; invited to Balmoral Castle, 217; elected a member of "The Club," 218; elected President at International Congress of Zoologists at Leyden, 224; resigns Directorship of Natural History Museum owing to failing health, 225, 232 ; appreciation of his services by Trustees, 225 ; his last years, 227-242 ; death, 243 ; memorial service in St. Luke's Church, Chelsea, 243; unveiling of memorial bust, I88; memorial tablet in meeting-room of Zoological Society, 224; list of works, Appendix III.

Hospital surgeon, ro

Army surgeon, 12 et seg.

Lecturer on Anatomy, 37

Curator of Hunterian Museum, 52 ; arrangement of specimens, 54; aids to study of anatomy, 55 ; character of his system, 57 ; "wet" preparations, 59; ingenious labelling, $6 \mathrm{I}$; casts of skulls, 63 ; study of brains of apes, 65 ; method non-controversial, 67 ; taxidermy, 69 ; views on animal painting, $7 I$; osteological catalogue, I9I

Hunterian Professor - subjects of lectures, 105, 106, Appendix II. Director of Natural History Museum, 137 ; arrangement of cases in Great Hall, 138 ; his classification, 140 ; taste in arrangement, I52; popularising the Museum, I 56, I 57; completion of "Whale Room," 230, 232

Cetacea, first studies, I66 ; essays and lectures on whales and whale 
Flower, Sir William, contd.fisheries, I68 et seq.; "whaling excursions," I69; exhuming a whale, 169; visits Leyden, Utrecht, and Louvain, I70; note on right whale, I75; on destruction of whales, 177

Museums, essays on-early museums, 181 ; on organisation of Natural History Museums, I 82 ; "research" and "instructional" arrangement, $182-185, \quad 187$; taxidermy, 186 ; remuneration of curators, 189

Anthropology, study of, 190; natural history of man, 193; evolution of race, 195 ; Anthropometry, 196 ; on primitive man, 197, 198; on pigmy races, 201 ; essay on "Fashion in Deformity," 201

Horse, lectures on, I 59, 21 3-2 I 5

Publications, 185 , and Appendix III.

Flower, Lady, marriage, 43 ; tributes to her husband, 44, 227 et seq. ; children, 45, 47; describes life at Lincoln's Inn Fields, 76 ; sketching in Egypt, 82; on friendship with Dean Stanley, 86,88 ; on Sir William's work at British Museum, 138 ; on visit to Balmoral Castle, 217; on visit to Windsor Castle, 218

Flower, Arthur Smyth (Sir William's eldest son), birth, 45 ; marriage, 2 I 3

Flower, Mrs. Arthur, 213

Flower, Captain Stanley (Sir William's second son), I 59, 2 I I ; appointed to management of Zoological Gardens at Cairo, 223, 236

Flower, Victor Augustine(Sir William's youngest son), I $n$., I 59, 212,242

Flower, Caroline Mary (Sir William's eldest daughter), birth, 47. See Shann, Mrs.

Flower, Vera (Sir William's second daughter). See Biddulph, Mrs.

Flower, Geraldine (Sir William's third daughter), 160, 234, 243

Flower, Augusta Frances (SirWilliam's youngest daughter), $87,89,235$, 243
Flower, James, Assistant in Hunterian Museum, 68, 169

Foster, Sir Michael, 238

Foster, Dr. Michael, 238

Fox, Charles James, 2 I 8

Fritsch, Gustav, 121

Froude's Life of Carlyle, Dean Stanley on, 89; Story of the Armada, 240

Fry, Mrs. Elizabeth, 8r

Fry, Right Hon. Sir Edward, 7

"Fucoid Bed" of Sutherland quartzites, 120

Gadow, Dr. Hans, assists with third edition of Osteology of the Mammalia, 104

Galton, Francis, F.R.S., 196, 197 ; tribute to Sir William Flower, 202

Garrick, David, 2 I 8

Garson, Dr. J. G., Assistant in Hunterian Museum, 57

Geikie, Sir Archibald, 224

Germany, Emperor of, confers order "Pour le Mérite" on Sir William Flower, 224, 231

Gibbon, Edward, 218

Gladstone, Right Hon. W. E. , I 58, 218 ; and Natural History Museum, 126, I 33 ; Tennyson on, 206, 209

Godman, F. G., presents collection of birds to Natural History Museum, I44, I 45

Goltstein, Baron Van, Minister for the Netherlands, 232

Goschen, Viscount, 2 I 8

Gould, John, his collection of humming birds, 134

Grant, W. Ogilvie, 70, 148

Gray, Captain David, "King of the Whalers," I 53, I 54

Gray, Dr. J. E., I3I

Gray, Professor Asa, 89

Greaves, Amelia (Sir William Flower's aunt), letter from, 4

Greaves, Celina. See Flower, Celina.

Greaves, John, of Radford Semele, Warwickshire (Sir William Flower's grandfather), 2

Greenhow, Henry, 9

Gregory, Mr., M.P. for Galway, I33

Gull, Sir William, 90

Günther, Dr., 70, I45, 147, I 84, 186

Gurney, Mr., 169 
Haden, Sir Francis Seymour, on disposal of the dead, 170

Hamilton, Lord George, 158

Hanbury, Sir Thomas and Lady, visit to, at "La Mortola," 237

Hanham, Lady, 232

Hannen, Lord, I 57

Harper, Dr. Gerald, 90

Heldenmaier, Dr., headmaster at Worksop School, 5, 6

Herbert, Sir Robert, 218

Herring, John F., painter, 7 I

Herschel, Sir William, 197

Hewitt, Mr. Prescott, 90

Hippocampus minor, 66

Hohenlohe, Prince Victor of, 158

Holland, summer tour in, $8 \mathrm{I}$

Holmes's System of Surgery, 38

Hooker, Sir Joseph, 64, 67, 124 n., 224, 243

Hornchurch, Essex, summer residence at, $8 \mathrm{I}$

Horse, The, a Study in Natural History, 1 59, 213-21 5

Hugel, Baron A. von, first Curator of Ethnological and Ethnographical Museum at Cambridge, 196

Hunt, Mrs. Holman, 233

Hunter, John, founder of Hunterian Museum, 49, 167

Hunterian Museum, 49; Sir William Flower elected Conservator of, 51 ; work in, 54 et seq.

Hunterian Professorship, Sir Richard Owen resigns, I0O ; Professor Huxley elected to, 100; Sir William Flower succeeds Professor Huxley, IOI ; inaugural address, 103 ; resigns his appointment, 136. Sec App. II.

Huxley, Professor, 48, 5 I, 82, 104, I $24 n ., 218$; at Cambridge meeting of British Association (1862), 66 ; friendship with Sir William Flower, 85 ; meeting with Dean Stanley, 88; letter from Sir William Flower, 100 ; elected Hunterian Professor, I0o; letter to Darwin, IOI ; letters to Sir William Flower, 125, I63; unveils statue of Darwin, 155; his interest in Marine Biological Association, 164, 165; at
Dublin meeting of British Associa tion (1878), I9I

Indian Institute encourages interest in races of Eastern Empire, 196

Inkerman, battle of, 27 ; heavy losses of 63 rd Regiment at, 27

Italy, travels in, $8 \mathrm{I}$

Jenner, Sir William, 90

Jeune, Sir Francis and Lady, 233

Johnson, Dr. Samuel, 218

Johnston, Sir Harry, study of primitive races, 198

Kelvin, Lord, 93, 218, 224, 231 ; visit to Natural History Museum, 232

Kensington Clergy Club, I6I

Kimberley, Earl of, 158

Kingsley, Rev. Charles, 80, 9 I

Knowles, James, editor of Nineteenth Century, architect of Lord Tennyson's house at Aldworth, 204

Kölliker, Albert von, his Manual of Human Histology translated, 86

Kuch Bahar, Maharajah of, present to Zoological Society, 162

Lambeth Palace, garden parties at, 216

Landseer, Sir Edwin, 7 I

Lankester, Professor E. Ray, I64, 165 ; contribution to Nature on Sir William Flower's work, 172

Lansdowne, Marquis of, 218

Lawrence, Sir Trevor, visit to, 228

Lecky, Right Hon. W. H., 218

Lectures, as Hunterian Professor, 104106. See Appendix II

Leighton, Lord, 148, 218

Lilford, Lord, $124 n$.

Limbs, origin of, I 13 et seq.

Lincoln's Inn Fields, home life at, 74 ; description of, 76 ; distinguished visitors, 79

Linnæus, his four primitive types of man, 197

Lister, Lord, 7, 67, 231

Longfellow, H. W., 79

Louise, H.R.H. Princess (Marchioness of Lorne), 218

Lowell, J. Russell, 79 
Lyall, Sir Alfred, 218

Lydekker, Richard, F.R.S., assists Sir William Flower with Intro. duction to the Study of Mammals, 213

Lyell, Sir Charles, 64, 67, 134

Ludlow, Lord, 232

Macaulay, Lord, and Sir Richard Owen, 130

M'Intosh, Professor, F.R.S., $165 n$.

Mackarness, Right Rev. J. F., Bishop of Oxford, 93

Mackay, Alexander, of Uganda, 199, 200

"Mammalia, Anatomy of the," course of lectures on, 104

Mammalia, in Natural History Museum, I 4 I

Mammalia, Osteology of, 104

Marazion, 221, 229

Marine Biological Laboratory at Plymouth, opening of, $163-165$

Markham, Sir Clements and Lady, 233

Marlborough House, garden parties at, 216

Maurice, Rev. F. D., 9I

Middlesborough Natural History Society, I6 I

Middlesex Hospital, Sir William Flower's service in, 10, 37,47 , 48

Middlesex Hospital Museum, Sir William Flower undertakes Curatorship of, IO; receives thanks of Court of Governors, 47

Millais, Sir John E., his pre-Raphaelite pictures, 7 I

Mimicry among insects, 146,147

Mineralogy, in Natural History Museum, 127, 140, I 44

"Modern Science Series," 2 I 3

Morgan, Campbell de, of University College, 7

Morris, Lady, 233

Müller, Professor Max, Science of Thought, 118

Mundella, Right Hon. Anthony J., 158

Murie, Dr., Assistant in Hunterian Museum, 57

Murray, George, R. M., F.R.S., I47, 187
Murray, Sir John, 231

"Museum Organisation," subject of Presidential address to British Association (1889), 180 et seq.

Museums, early, I8I ; management of, I82-187. See Natural History Museum and Hunterian Museum

Museums, Essays on, 3, 44, 197

Nansen, Dr., 157

National Sunday League, I 50

Natural History Museum, memorial for change in administration, $124 n$. ; Sir William Flower appointed Director of, I 25; removal to South Kensington, I3I ; Central Hall, I39-I 45 ; popular interest in, $141,148,157,203$; opening of, on Sundays, I50; distinguished visitors to, I57, I 58, 204, 232, 233; first General Guide issued, $16 \mathrm{I}$; Sir William Flower resigns Directorship of, 225,232 ; memorial bust of Sir William Flower, 188

Newcastle, meeting of British Association at (1889), 180

Newstead Abbey, visit to, 228

Newton, Professor Alfred, $124 n$.

Northbrooke, Earl of, 158

Northcote, Lord, I 58

North Repps, exhumation of whale at, 169

North Sea Marine Laboratory, I65

Northumberland, Duke and Duchess of, visits to, 211,228

Norwich, Bishop of, $88 n$.

Osteology of Mammalia, $\mathrm{IO}_{4}$; Emin Pasha's appreciation of, 200

Osterley, garden parties at, 216

Owen, Sir Richard, Hunterian Lecturer to Royal College of Surgeons, 49, 53, 104, 129, 226 ; reads paper on brains of apes at meeting of British Association (1862), 65; resigns Hunterian Professorship, I00, and Superintendentship of Zoological Departments of British Museum, 123, 125; his death, 123; his connection with British Museum, 
I30; advocates removal of Rolleston, Professor, 67, 192

Natural History exhibits to Romanes, Professor G. J., 122

South Kensington, I31-I35; Rosebery, Earl of, 218

memoir by Sir William Flower,

133; statue of, in Natural

History Museum, 150, 222

Oxford, Bishop of, 93, 218

Oxford, meeting of British Association at (1894), 192

Oxford University, "Readership" in Anthropology established, 196; Sir William Flower receives degree of D.C.L., 224

Paget, Sir James, 51, 67, 80, I24, 136

Palæontology, growth of knowledge of, 96

Paris, "School" of Anthropology at, 193

Pearson, W., Assistant in Hunterian Museum, 52, 61

Peel, Lord, Speaker of the House of Commons, 124

Penzance, remains of whales at, 2 Io

Pettigrew, Professor, Assistant in Hunterian Museum, 57

Pickhardt, Mr., his lifelike taxidermy, I 87, 220

Plant-remains, I 20, I 2 I

Plymouth, Marine Biological Laboratory at, 163-165

Powell, Sir Richard Douglas, 229, 240

Quadrumana, study of, 65

Quain, Professor, Io I

Que, M., 196

Quekett, Dr., Curator of Hunterian Museum, 49, 53

Ramsay, Professor Andrew, I $24 \boldsymbol{n}$.

Ramsay, Mr. Wardlaw, I 44

Reade, Rev. J. B., Vicar of Stone, 43

Reinhardt, Professor, 176

Reynolds, Sir Joshua, 2 I 8

Rivers, General Pitt, 195

Riviera, Sir William Flower winters in, 234, 235

Riviere, Briton, R.A., 7 I

Roberts, Dr. 196

Roller (Coracias garrulus), II 9

Rosherville Gardens, whale at, 169

Ross, Sir James, I 77, 178

Royal College of Surgeons, Sir William

Flower passes examination for membership, Io; takes diploma of, 37 ; becomes Curator of Hunterian Museum in, 51 ; appointed Hunterian Professor, IOI; resolution by Council on resignation of Curatorship, 136

Royal Institution, popular lectures at, 212

Royal Society, Sir William Flower elected a Fellow of, Ior ; VicePresident of, IOI

Ruskin, John, contributions to Mineralogical Department of Natural History Museum, I 44

St. Levan, Lord, 229

St. Quintin, W. H., presents antlers of stag to Natural History Museum, 142

Salisbury, Marquis of, 218, 23I ; letter, from, intimating honour of C.B., 163, and K.C.B., 215

Salvin, Mr., presents collection of birds to Natural History Museum, 144

San Carlos, Marquise de, 233

San Remo, 235

Schleswig-Holstein, H.R.H. Prince Christian Victor of, $2 I_{7}$

Schliemann, Dr., 79

Sclater, Dr. P. L., F.R.S., on Osteology of the Mammalia, 104

Scutari, hospital at, 36 . See App. I.

Sebastopol, siege of, 23 et seq. See Appendix I.

Seebohm, Henry, 146

Selborne, Earl of, Lord Chancellor, 124

Shakespeare Tercentenary, I

Shann, H. C., of Micklegate, York, 238

Shann, Mrs. H. C. (Sir William Flower's eldest daughter), early life at Lincoln's Inn Fields, 75, $\mathbf{7 7 - 8 0}, \mathbf{1 9 0}$; letter to, 235

Sharpe, Dr. Bowdler, 70, 148 
Sharpey, Dr., of University College, 12

Sherbrooke, Lord, 126

Sheridan, Richard Brinsley, 218

Siam, King of, 79

Sibley, Septimus, 9

Sidlesbarn, grampus caught at, 17 I

Sion College, lecture on whales at, I6I

Sloane, Sir Hans, herbarium of, I 34

Smith, Adam, 218

Smith, Right Hon. W. H., I 58

Smyth, Captain John, founder of Virginia, 4 I

Smyth, Admiral William Henry, K.S.F., family of, $40,4 \mathrm{I}$; his offices and scientific pursuits, 42 , 43

Smyth, Sir Warington, F.R.S., 4 I

Smyth, Lady Warington, 229

Smyth, Charles Piazzi, AstronomerRoyal for Scotland, 4I

Smyth, General Sir Henry Augustus, K.C.M.G., Governor of Malta, 4I, 229

Smyth, Henrietta, wife of Rev. Professor Baden-Powell, 4I

Smyth, Ellen, wife of Captain $\mathrm{H}$. Toynbee, 4I, 103

Smyth, Georgiana Rosetta. See Flower, Lady

Sperm oil, commercial value of, I 75

Sperm whales. See Whales

Spottiswoode, Dr. William, I8o

Stanhope, Earl, $15^{8}$

Stanhope, Right Hon. Edward, 158

Stanley, Arthur Penrhyn, Dean of Westminster, 79, 9r, 217; Sir William Flower's friendship with, 84 ; marriage, 84 ; attitude to Darwin's Origin of Species, 86 ; love for children, 86,89 ; meeting with Darwin, 87 ; repartee, 88; baptizes SirWilliam's youngest child, 89 ; opinion of Froude's Life of Carlyle, 89 ; death, 89

Stanley, Lady Augusta, marriage, 84 ; tribute by Lady Flower, 85,86 ; Sir William Flower's youngest daughter named after, 87,89

Stanley, Capt. Owen, of H.M.S. Rattlesnake, 84

Stanley, Sir H. M., 200
Stanley, Right Rev. Edward, Bishop of Norwich, $88 n$.

Stephen, Leslie, 2 I $9 n$.

Stewart, Professor, Curator of Hunterian Museum, 52

Stratford-on-Avon, birthplace of Sir William Flower, I

Struthers, Professor, on structure of whales, II I

Stubbs, Bishop, 23 I

Switzerland, tours in, $8 \mathrm{r}, 160,2 \mathrm{I}$, 221,228

Syon House, garden-parties at, 216

Tankerville, Earl of, visits to, 2 r2, 228

Tasmanian skull, ro7-109

Taxidermy, Sir William Flower advocates lifelike work in, 69, 186

Taylor, Lady Jane, 233

Temple, Most Rev. Frederick, Archbishop of Canterbury, 234

Tennyson, Lord, visits Natural History Museum, 204; Sir William Flower visits, at Aldworth, 204209

Tennyson, Lady, 205

Tennyson, Hallam (2nd Baron), 205 et seq.

Thomas, Oldfield, F.R.S., 148

Thompson, Sir Edward Maunde, 22 r, 233

Thomson, Professor A., on Physical Anthropology, 196

Tollemache, Lord, and Lady, visit to, 228

Torpedo, electric organs of, 121

Toynbee, Captain H., $4 \mathrm{I}$

Toynbee, Mrs., 4I, I03

Tristram, Canon, $124 n$.

Turner, Sir William, 172

Tweeddale, 9th Marquis of, 106 ; collection of bird skins in Natural History Museum, 144

Tylor, Dr. E. B., works on Anthropology, 192; lectures at Oxford, I96

University College, London, 7

Ventimiglia, 237

Veterinary College, Sir William Flower appointed examiner, 56 
Victoria, Queen, presents war medal to Sir William Fowler, 37 ; lends cottage in Richmond Park to Sir Richard Owen, 123; Jubilee celebrated by Zoological Society, I6I ; presents insignia of K.C.B. to Sir William Flower, 216; Sir William's visit to, at Balmoral, 217

Virchow, Professor, 79, 157; describes Sir William Flower as the "Prince of Directors," 187

Walden, Lord Howard de, $124 n$.

Wallace, Alfred Russel, 64, I 24, I34

Wallace, Sir Donald M., 2 I 8

Walsingham, Lord, 123, 220 ; presents collections to Natural History Museum, I42, 144

Ward, Rowland, his lifelike taxidermy, 187

Waring, Captain, his whale charts, I 76

Warington, Annarella, wife of Admiral W. H. Smyth, 41 ; incident at dinner to Lord Nelson, 4I, 42 ; her accomplishments, 42

Warington, Thomas, English Consul at Naples, $4 \mathrm{I}$

Wartz, his Anthropologie der Naturvolken, 192

Waterhouse's Life Histories of Insects, 220

Wellington College, lecture to boys at, I 59

Wellington, Duke of, reminiscences by Duke of Argyll, 207

Westminster Abbey, services in, 86; Innocents' Day in, 87 ; service on evening of Dean Stanley's death, 89

Westminster, Dean of, 243

Whalebone, origin of, I 15

Whale fisheries-British and Colonial,
172, 174; Basque, 173; Cruise of the "Cachalot," 174, 241 ; right, 174, I76; sperm, 175

Whale Room in Natural History Museum, 230, 232

Whales, studies of, 166 et seq. ; sperm, 167,171 , 175; Greenland, 168, 176; narwhal, 168; Chinese dolphin, 168; Berardius, 168 ; essays and lectures on, 168 et seq.; "whaling excursions," 169 ; white whale, I7I; bottlenose, 175 ; right, 175 et seq. ; habits of, 177 ; jaw-bones used as gateposts, etc., 178,179

Wharncliffe, Lord and Lady, visit to, at Wortley, 160

White-Cooper, Dr., 240

Wickham, Dr., Headmaster of Wellington College, I 59

Wilson, William, his herbarium, 134

Windsor Castle, Sir William and Lady Flower conducted through by Princess Louise, 218

Wolf, Joseph, painter, 7 I

Wolseley, Viscount, 212, 218

Woodward, Dr. A. S., F.R.S., 148

Worksop, school at, 5, 6

Writings, List of, by Sir William Flower. See Appendix III.

York, meeting of British Association at $(188 \mathrm{I}), 192$

Zoological Gardens, visits to, 78, 79

Zoological Society of London, Sir William Flower elected Fellow of, I0 ; elected President of, 106 ; Jubilee garden party in Society's Gardens, 161 ; summary of its history (1887), 162 ; memorial tablet to Sir William Flower in Society's meeting-room, 264 
Works by Sir WILLIAM HENRY FLOWER, K.C.B., D.Sc., etc.

Crown 8vo. I I 6 . 6 .

AN INTRODUCTION TO THE

OSTEOLOGY OF THE MAMMALIA

BEING

THE SUBSTANCE OF THE COURSE OF LECTURES

DELIVERED AT THE ROYAL COLLEGE OF SURGEONS OF ENGLAND IN I870

With numerous Illustrations.

8vo. I 2s. net.

\section{ESSAYS ON MUSEUMS}

\section{AND OTHER SUBJECTS CONNECTED WITH}

NATURAL HISTORY

$A T H E N A E U M$.- "Many of the essays possess permanent value, and all were well worthy of being printed afresh."

DAILY CHRONICLE._" There is, in short, a large mass of interesting and solid information in the volume; and we think that Sir William Flower has been well advised in collecting together these several fugitive"articles and addresses. They cannot fail to interest and instruct a wide public."

GUARDIAN.- "Supply interesting and valuable reading as well as practical instruction."

MACMILLAN AND CO., LTD., LONDON. 


\section{THE CAMBRIDGE NATURAL HISTORY.}

Edited by S. F. Harmer, Sc.D., F.R.S., and A. E. Shipley, M.A. Medium 8vo. I7s. net each.

VOLUMES NOW READY.

Vol. II. WORMS, ROTIFERS, AND POLYZOA. By F. W. Gamble, M.Sc., Miss L. Sheldon, A. E. Shipley, M.A., M. Hartog, M.A., W. B. Benham, D.Sc., F. E. Beddard, M.A., F.R.S., and S. F. Harmer, M.A.

Vol. III. MOLLUSCS AND BRACHIOPODS. By Rev. A. H. Cooke, A. E. Shipley, M.A., and F. R. C. Reed, M.A.

Vol. V. PERIPATUS, MYRIAPODS, INSECTS. Part I. By A. Sedgwick, M.A., F.R.S., F. G. Sinclair, M.A., and D. ShaRP, M.A., F.R.S.

Vol. VI. INSECTS. Part II. By D. Sharp, M.A., F.R.S.

Vol. VIII. AMPHIBIA and REPTILES. By H. Gadow, M.A., F.R.S.

Vol. IX. BIRDS. By A. H. Evans, M.A.

Vol. X. MAMmalia. By F. E. Beddard, M.A. (Oxon.), F.R.S. (Prosector to the Zoological Society).

\section{IN PREPARATION.}

Vol. I. PROTOZOA. By Marcus Hartog, M.A., D.Sc.; SPONGES, by W. J. Sollas, Sc.D., F.R.S. ; JELLY-FISH, SEA-ANEMONES, Etc., by S. J. Hickson, M.A., F.R.S. ; STAR-FISH, SEA-URCHINS, ETc., by E. W. MACBRIDE, M.A.

Vol. IV. SPIDERS, MITES, ETc., by C. Warburton, M.A. ; SCORPIONS, TRILOBITES, ETc., by M. LAURIE, B.A., D.Sc. ; PYCNOGONIDS, by D'ARcy W. Thompson, M.A., C.B. ; LINGUATULIDA and TARDIGRADA, by A. E. ShIPLEY, M.A. ; CRUSTACEA, by W. F. R. WeLDon, M.A., F.R.S.

Vol. VII. BALANOGLOSSUS, Etc., by S. F. Harmer, Sc.D., F.R.S.; ASCIDIANS and AMPHIOXUS, by W. A. Herdman, D.Sc., F.R.S. ; FISHES, by T. W. Bridge, Sc.D., and G. A. Boulenger, F.R.S.

[In the Press.

MACMILLAN AND CO., LTD., LONDON. 




\section{PLEASE DO NOT REMOVE CARDS OR SLIPS FROM THIS POCKET}

\section{UNIVERSITY OF TORONTO LIBRARY}

QL Cornish, Charles John

31 Sir William Henry Flower

F6C8

BioMed 


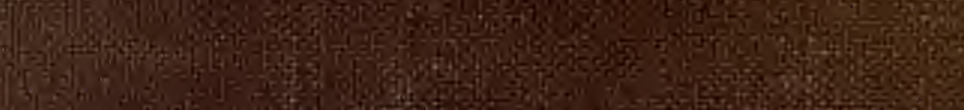

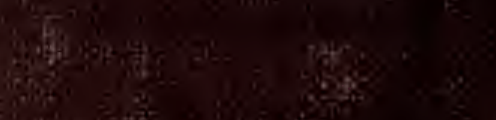

ond

5.

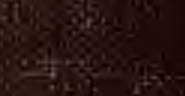

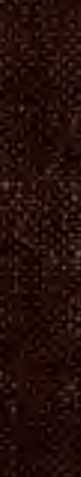

